\title{
السلوك الإداري لمديري المدارس الإعدادية وفقاً لنظرية رنسيس ليكرت (نظام 1- نظام4 ) وعلاقته في الروح المعنوية للمدرسين والمدرسات في مركز قضاء الكوت.
}

\author{
م.د مبد كاطع سموم \\ جامعة واسط
}

ملخص البحث

مشكلة البحث :

لاحظ الباحث من خلال الزيارات الميدانية للمدارس وخاصة في تطبيق طلبة المرحلة الرابعة أن

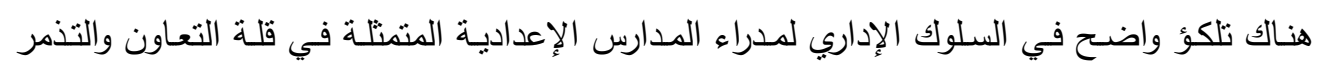

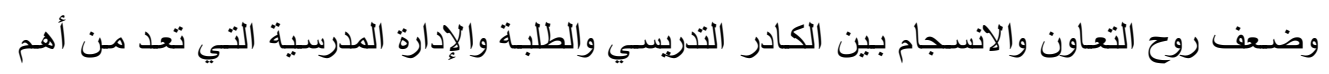

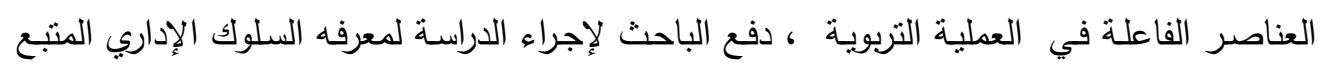

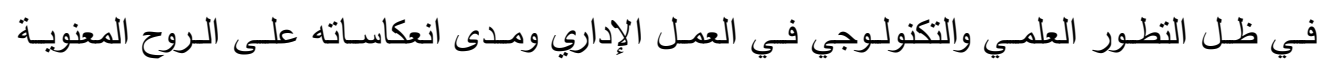
للتدريسيين في تلك المدارس.

أهمية البحث : أهية الدراسة تتضح من خلال الآتي :

1- أن تكون هذه الدراسة لها انعكاسات ايجابية على الميدان الإداري التربوي ، بتوفير أساس سليم

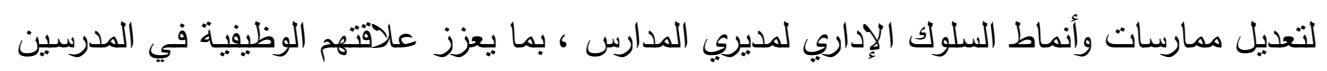

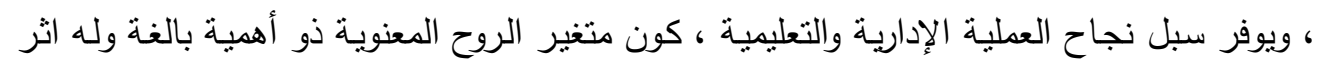

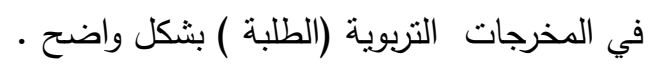

ץ- أن نسهم هذه الدراسة في الكثف عن مستوى النمط الإداري في ظل نظرية (ليكرت ) لمدري المدارس الإعدادية 


\section{العـــــــدد الثاني والعشرون}

\section{مجلــــة كليــــة التربيــــة}

أهداف البحث : يهدف البحث إلى التعرف على أنماط السلوك الإداري لمديري المدارس الإعدادية وفقا لنظرية رنسيس ليكرت (نظام1- نظام 4 ) ) ، وبيان العلاقة في الروح المعنوية للمدرسين من خلال الإجابة على الأهداف الآتية :

1 - ما درجة الأنماط الإدارية السائدة لدى مديري المدارس الإعدادية وفقا لنظرية رنسيس ليكرت. r- ما درجة الروح المعنوية السائدة لدى مدرسيين المدارس الإعدادية من وجهة نظرهم •

ب- هل توجد علاقـة ذات دلالـة إحصـائية في السـوك الإداري لدى مدراء المدارس الإعداديـة وفقا لمتغيري النوع ( ذكور - إناث ) وسنوات الخدمة.

ع - هل هناك علاقة ارتباطية بين درجة الأنماط الإدارية الأربعة لدى مدراء المدارس الإعدادية وفقا لنظرية ( ليكرت ) نظام (1-ع ) والروح المعنوية لدى مدرسين.

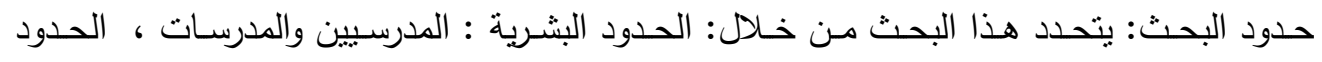

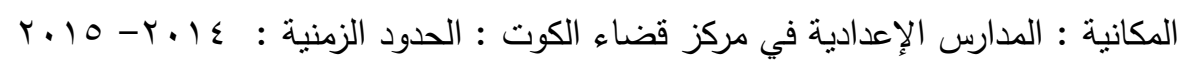
تحديد المصطلحات : n

(Administrative Styles ) : الأنماط الإدارية

السـوك الذي يمارسـه مدير المدرسـة للتأثير الفعال في سلوك المدرسين في المدرسـة، بهدف تحسين نوعية العمل والإنتاج في المدرسة، ويقاس بالدرجة الكلية التي يحصل عليها المستجيب على فقرات أداة قياس مستوى الأنماط الإدارية ، وفقاً لنظرية ليكرت (Likert) ) .

الروح المعنوية(Morale) ) "إن الروح المعنويـة ظاهرة نفسية تتأثز في ارتفاعها وانخفاضها بالعديد

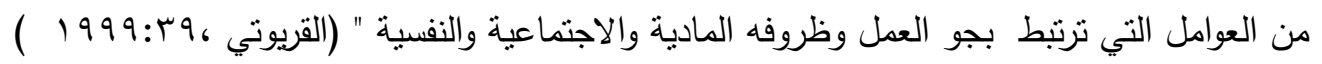




\section{العـــــــد الثاني والعشرون}

منهج البحث : تم استعمال المنهج الوصفي ألارتباطي لنوضيح العلاقة بين أنماط السلوك الإداري

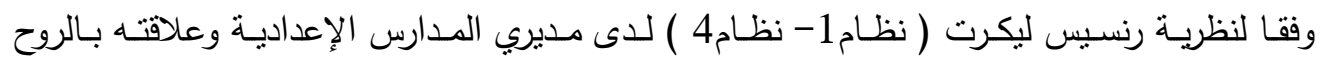

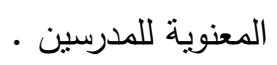

مجتهع البحـث : يتكسون مجتمـع البحـث مـن جميـع المدرسين والمدرسـات في المـارس الإعداديـة

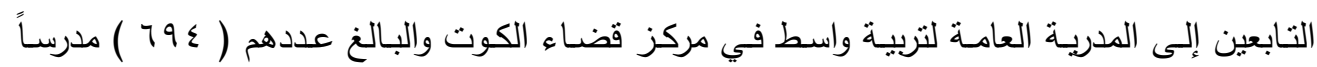

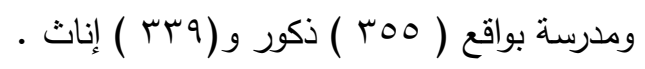

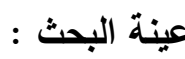

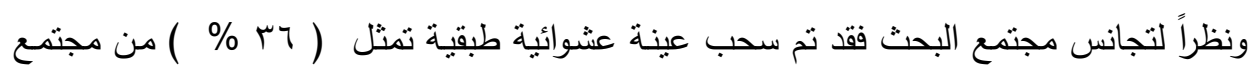

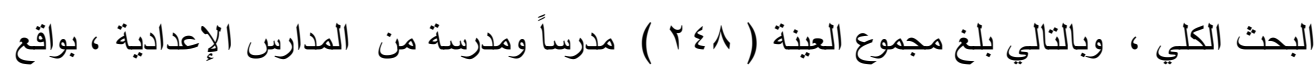

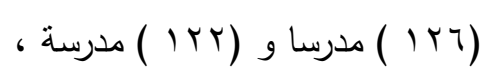

الاستتتاجات : من أهم الاستتناجات ما يلي :

1- إن المدراء يتبعون السلوك أداري وفقا لنظرية ليكرت نظام (1-؛ ) بدرجه كبيره .

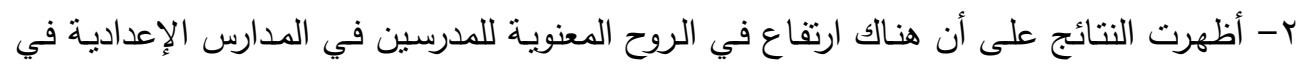

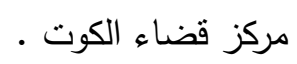

r - وجود علاقة ارتباطيه ضعنيفة بين السلوك الإداري والروح المعنوية للمدرسين. التوصيات :من أهم التوصيات ما يلي :

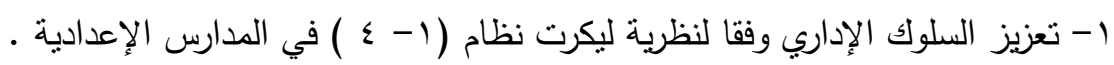

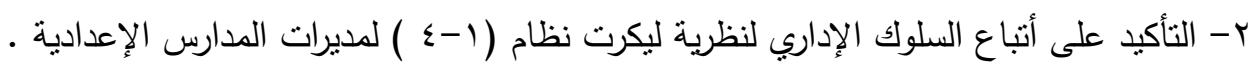

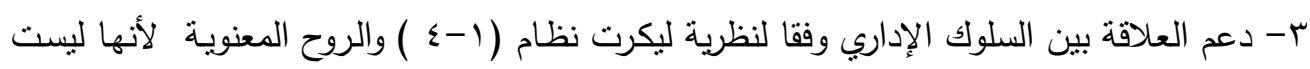

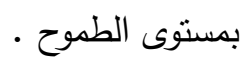




\section{العـــــــد الثاني والعشرون}

\section{مجلـــة كليـــة التربيــة}

المقترحات : يقترح الباحث ما يلي :

1- إجراء مزيد من الدراسات لتطبيق السلوك الإداري لنظرية ليكرت نظام (1-؛ ) مع متغيرات أخرى

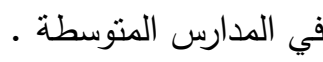

ץ- إجراء دراسة لمعرفة الروح المعنوية وعلاقتها بالجودة التعليمية .

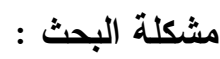

لاحظ الباحث من خلال الزيارات الميدانية للمدارسة وخاصـة في تطبيق طلبة المرحلة الرابعة أن

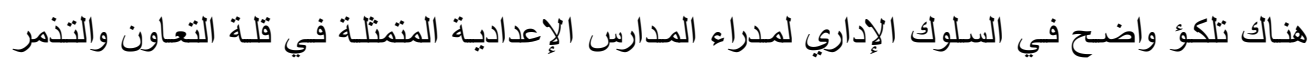

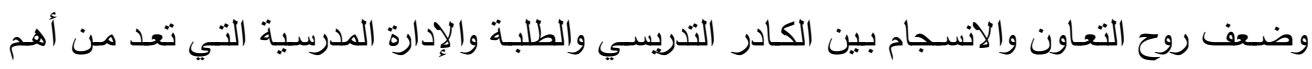

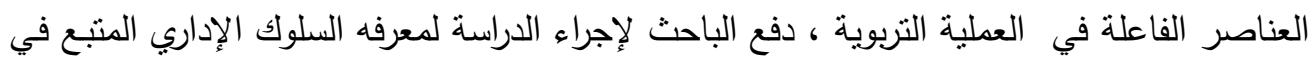

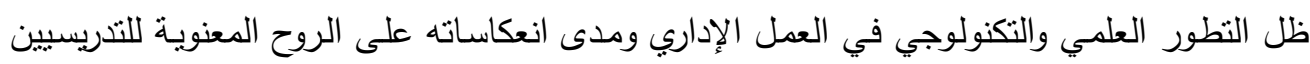

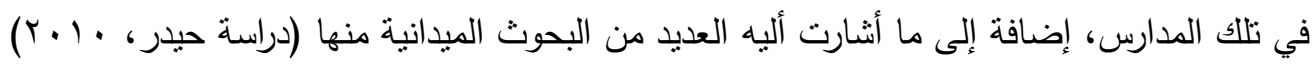

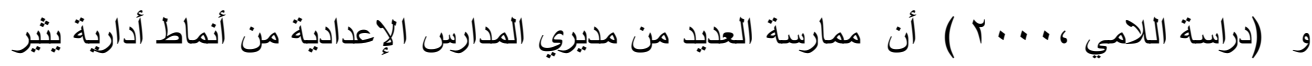

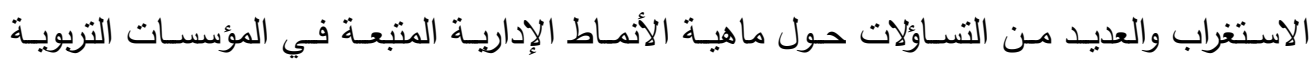

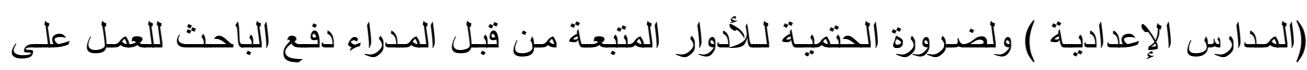

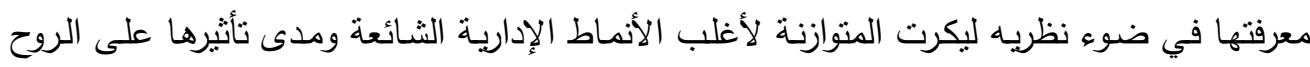

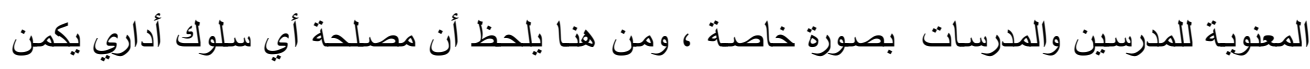

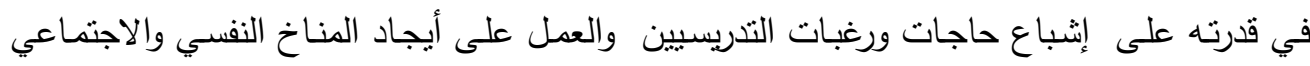
المناسب لهم.

إن مدير المدرسة الفعال هو الذي يحدث نمط أداري له تأثثراً ايجابيا في المناخ التربوي بوجه عام

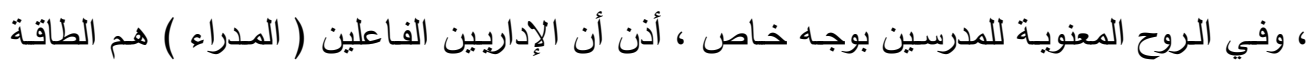

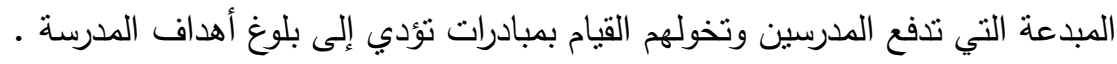




\section{العـــــــد الثاني والعشرون}

\section{مجلـــة كليـــة التربيـــة}

\section{أهمية البحث :}

يستمد البحث أهميته من خلال تتاوله لأهم عنصريين في نجاح العملية التربوية في المدرسة هما

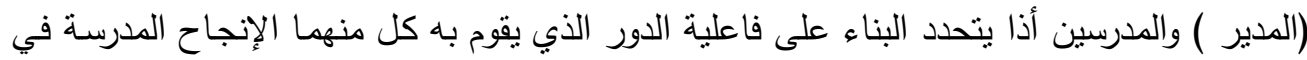

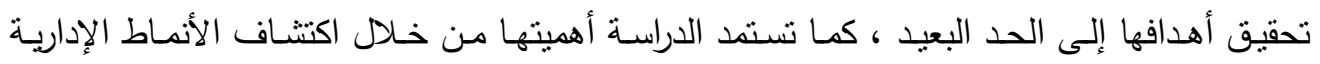

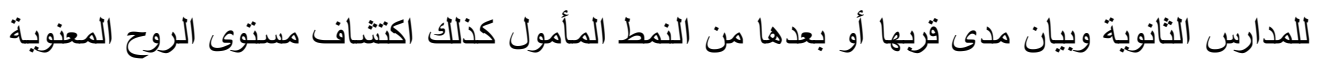

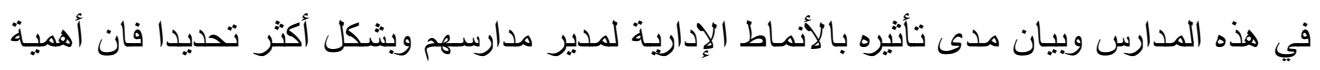

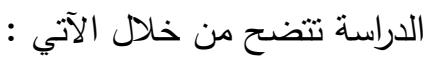

1- إن تكون هذه الدراسة لها انعكاسات ايجابية على الميدان الإداري التربوي ، بتوفير أساس سليم

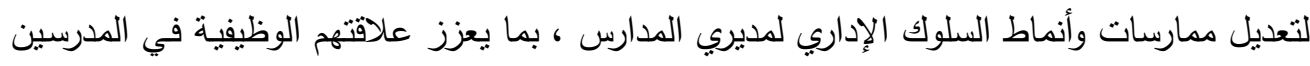

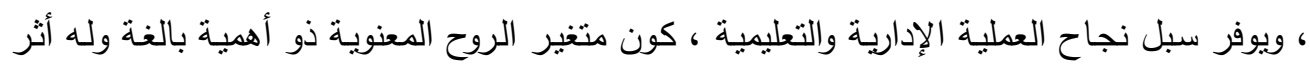

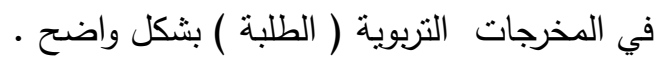

r- إن تسهم هذه الدراسة في الكثف عن مستوى النمط الإداري في ظل نظرية ( ليكرت ) لمدري المدارس الإعدادية

\section{أهداف البحث :}

يهدف البحث إلى التعرف على أنماط السلوك الإداري لمديري الدـارس الإعدادية وفقا لنظريـة

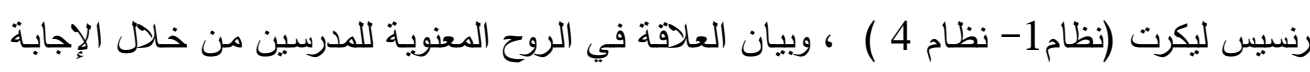

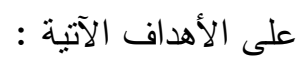

1- ما درجة الأنماط الإدارية السائدة لدى مديري المدارس الإعدادية وفقا لنظرية رنسيس ليكرت. r- ما درجة الروح المعنوية السائدة لدى مدرسيين المدارس الإعدادية من وجهة نظرهم . 


\section{العـــــــد الثاني والعشرون}

\section{مجلـــــة كليـــــة التربيــــة}

r- هل توجد علاقة ذات دلالة إحصائية في السلوك الإداري لدى مدراء المدارس الإعدادية وفقاً

$$
\text { لمتغيري النوع ( ذكور - إناث ). }
$$

ع - هل هناك علاقة ارتباطية بين درجة الأنماط الإدارية الأربعة للى مدراء المدارس الإعدادية وفقا لنظرية ( ليكرت ) نظام (1-؛ ) والروح المعنوية لدى مدرسين. حدود البحث: يتحدد هذا البحث من خلال: 1- الحدود البشرية الددرسيين والمدرسات. r- الحدود المكانية : المدارس الإعدادية في مركز قضاء الكوت

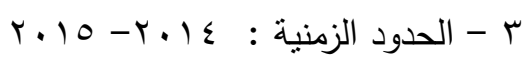
تحديد المصطلحات :

(Administrative Styles ) : الأنماط الإدارية

السلوك الذي يمارسـه مدير المدرسـة للتأثير الفعال في سلوك المدرسين في المدرسـة، بهدف

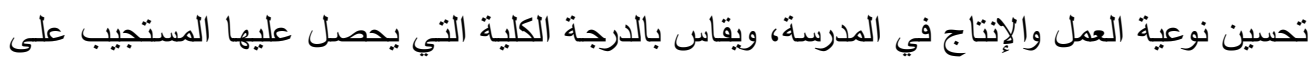

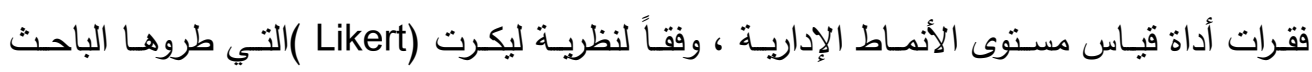

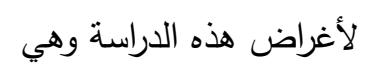

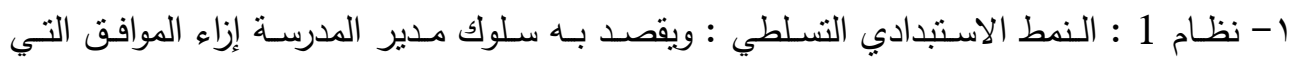
يواجهها أثناء عملة اليومي للتأثير في سلوك المدرسين عن طريق الاستبداد والتسلط والدكتانورية ץ- نظام 2 : النمط الاستبدادي الخير : ويقصد به سلوك المدير أثناء عملة اليومي للتأثير في سلوك الددرسين عن طريق الخوف والتهديد، ولكن بصورة اقل من نظام 1. 


\section{العــــــد الثاني والعشرون}

\section{مجلـــة كليـــة التربيـــة}

r- نظام 3 : النمط الاستشاري الديمقراطي : ويقصد به سلوك المدير أثناء عملة اليومي للتأثير في سلوك المدرسين ، بحيث يشرك الدرسين في صنع القرارات اليومية .

ع - نظام 4 : النمط ألثتاركي الديمقراطي : ويقصد بـه سلوك المدير أثناء عملة اليومي للتأثنر في سلوك المدرسين من خلال تفويض الصلاحيات والسلطات وإنرالك المدرسين في صنع القرارات

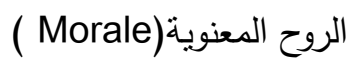

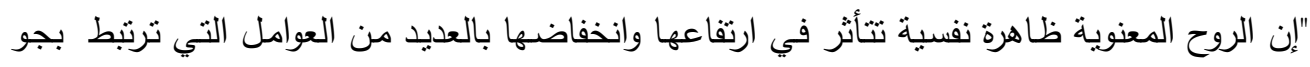

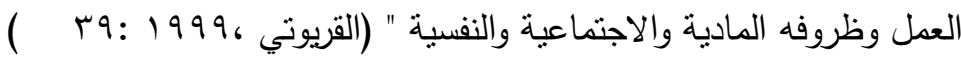
يعرفها الباحث إجرائيا:

هي الدرجة الكلية التي يحصل عليها المستجيب (الدرسين ) على الأداة (الاستبانه ) المعدة لهذا

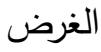

التعرف النظري: هي الحالة الوجدانية والإنسانية والرضـا الوظيفي للمدرسين العاملين في المدارس

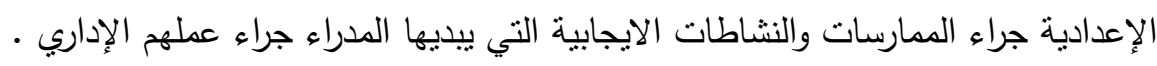

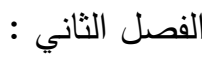

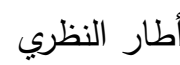
فيمـا يلبي عرض لأبـرز جوانب الأدب النظري المتعلق بمتغيري الدراسـة الأنمـاط الإداريـة والـروح

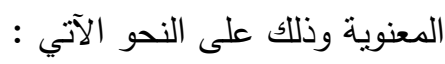

اولا الأنماط الإدارية : (Administration System ) 


\section{العـــــــد الثاني والعشرون}

\section{(1)}

مجلـــة كليــــة التربيـــة

نطور الفكر الإداري منذ الولادة الإدارة العلمية عام 1911 علي يد فريدريك تايلور ، إذ ظهرت

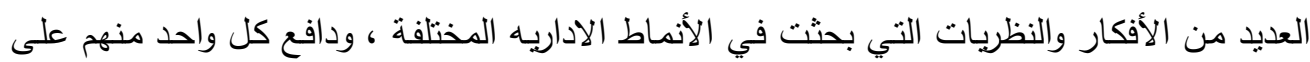

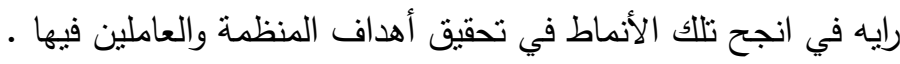

أكد رنسيس ليكرت · Rensis Likert) وزملائهـه من جامعـة مشيكن أن الإداريين الذين

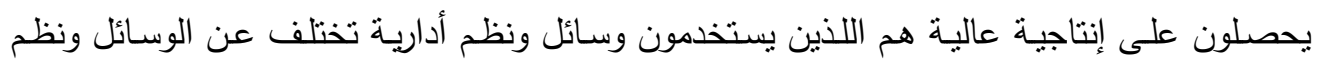
الثقليدية التي بطبقها المدراء الفاثلون ، وقد استطاع ليكرت وزملائه النوصل إلى أطار عام لنظرية

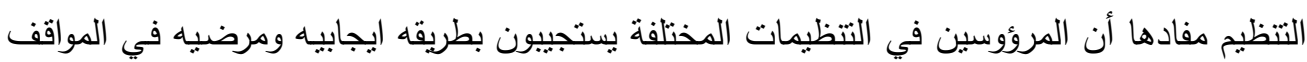

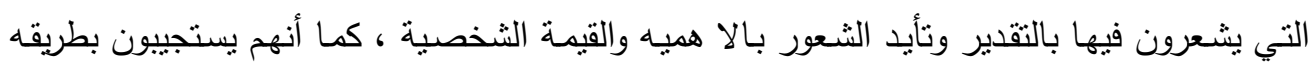

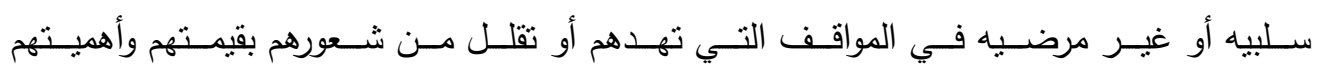

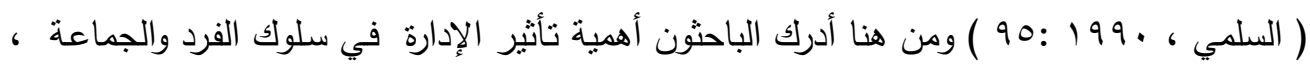

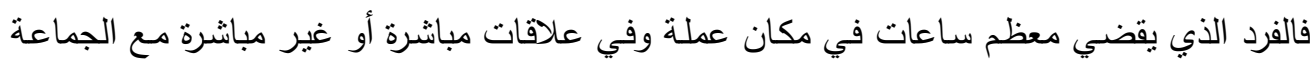

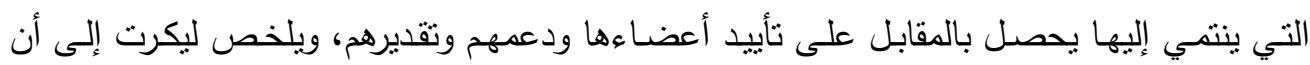

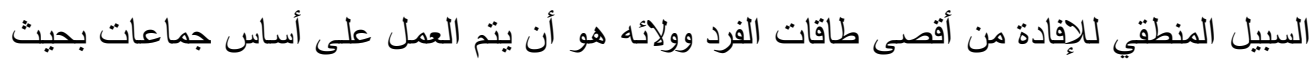

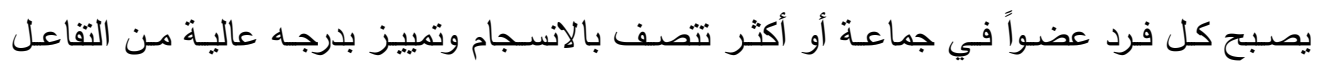

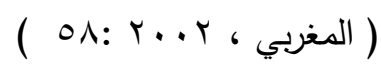

لقد ركزت الدراسات على تحليل الأنماط الاداريه ، وتتبع السلوك الإداري ، وزاد زخمها مع رواج

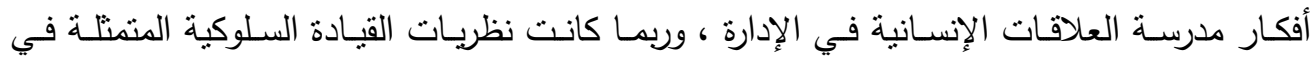

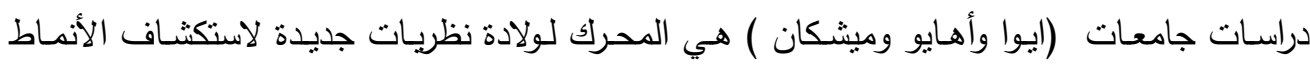

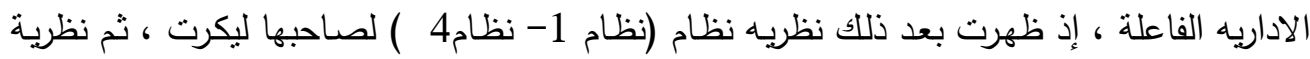

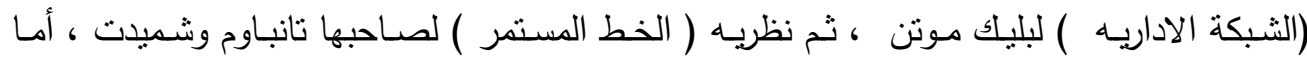
المرحلة الثانية فقد مثلتها مجموعة من النظريات (الموققية - الثرطية )، بدا بالنظرية ( الظرفية ) )

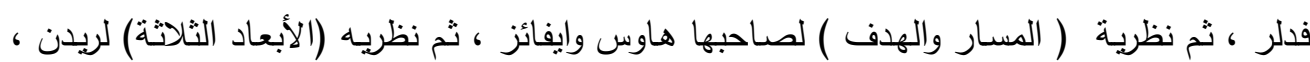

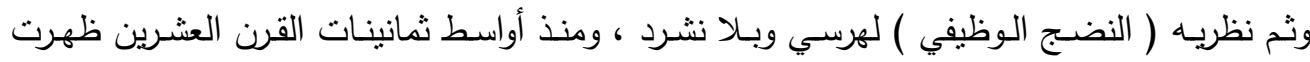

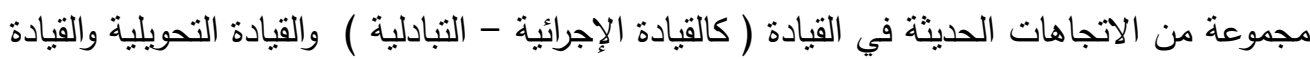
المتسامية وقياده الإدارة ) وغيرها . 


\section{العـــــــد الثاني والعشرون}

وفي مطاع الستينات من القرن العشريين ، وفي خضم بروز مدرسـة العلاقات التشـاركيه ، قدم

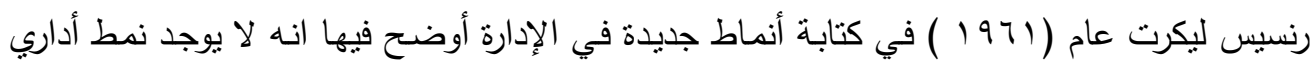

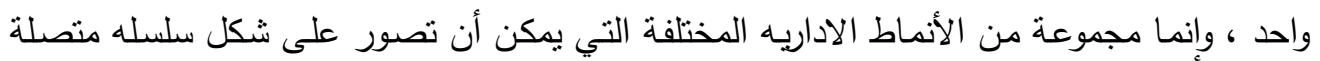

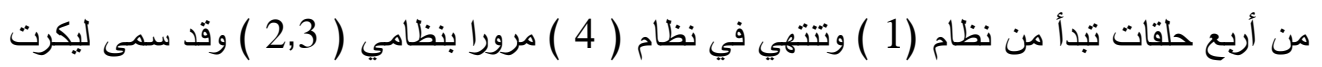

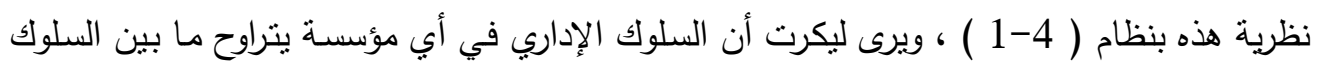

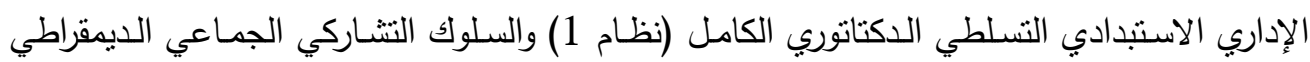
الكامل ( Likert,1961:94 ) وذلك على النحو الآتي:

1- النمط الاستشاري الديمقراطي (System Democratic Consultative):

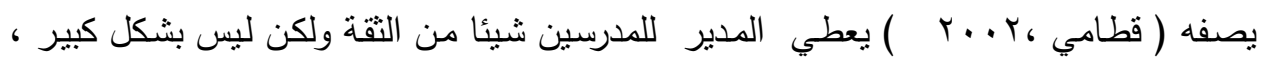

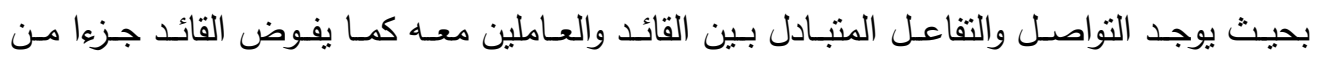

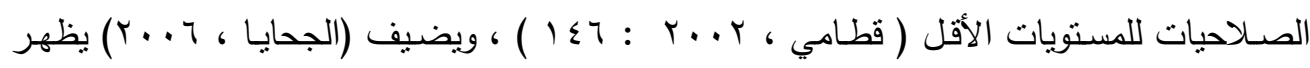

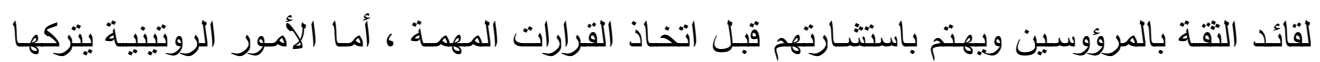

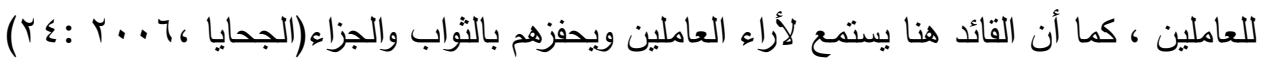
r- النمط الاستبدادي التسلطي: (System Exploitative Authoritative)

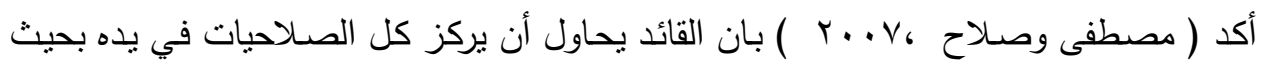

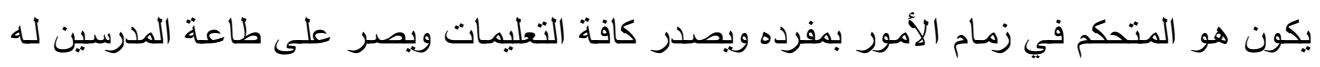

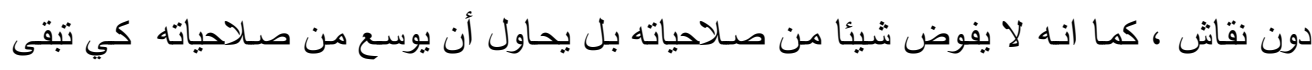

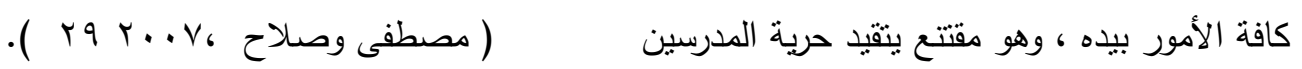
ويضيف (العتيبي وآخرون ، V . . r) أن هذا النمط يتصف بالمركزية الثديدة وقلة الثقة بين المدير

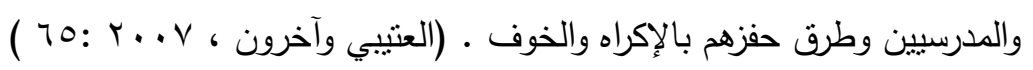

إن المدير المستبد يبدوا انتقادي يهدد كثيرا لاعتقاده بأنه من الضروري الضغط على المدرسين

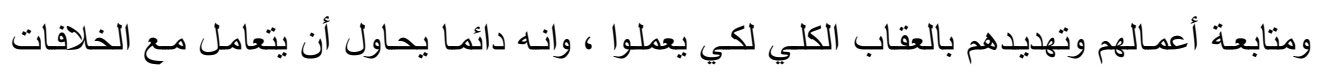




\section{العـــــــد الثاني والعشرون}

والصراعات داخل التظيم لإخمادها ، وإذا احد خالفه في الرأي فانه يعدهُ تحديًا لسلطته ولا يغفر

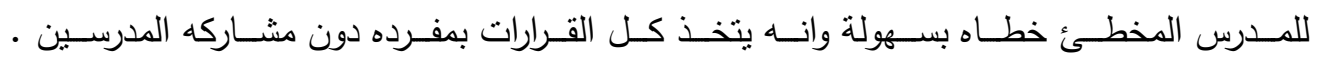

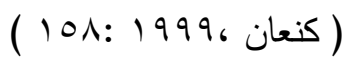

r- النمط الاستبدادي الخير ( System Benevolent Authoritative ) :

الددير الخير وان كان يبدوا عادلا وطييا أحيانا في تعامله مع مرؤوسيه ، ألا أن اتجاهاته وميوله

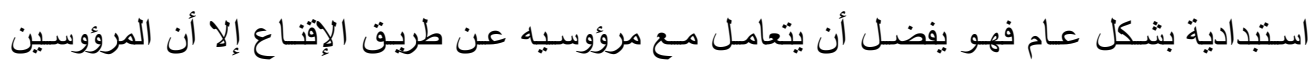

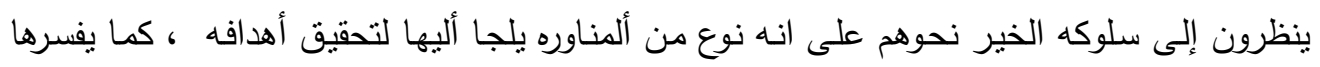

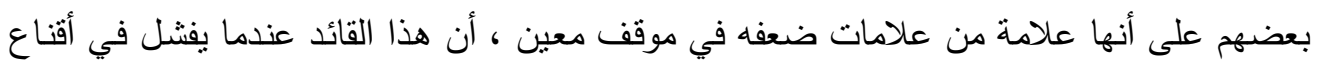

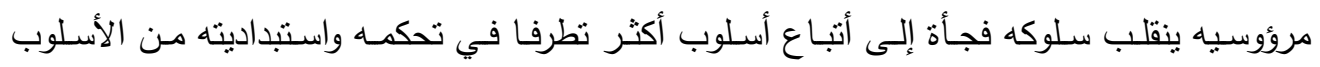

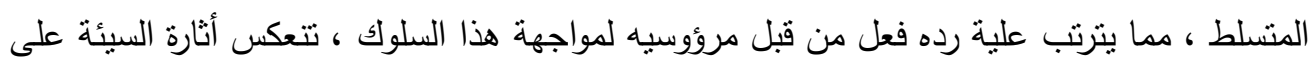

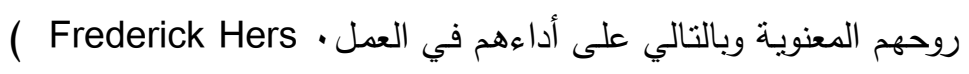
berg , 1959 )

ع-النمط النتاركي الديمقراطي (System Participative Democratic):

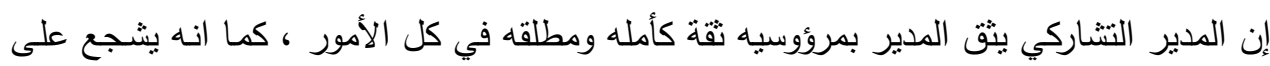

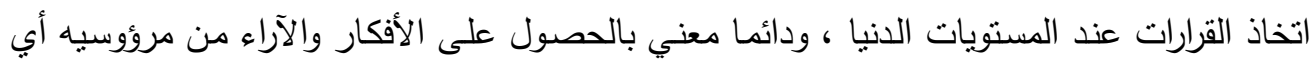

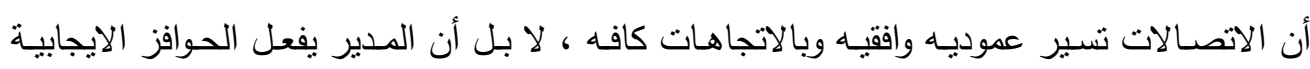

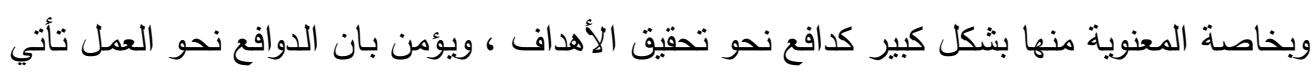

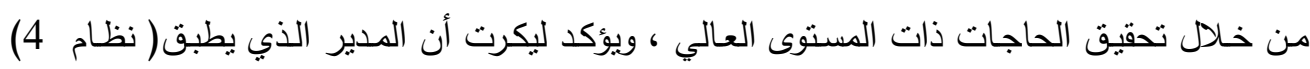

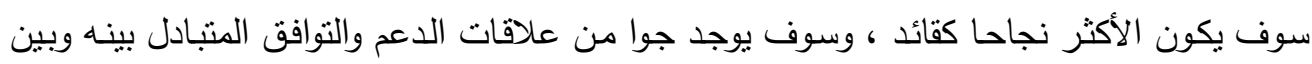

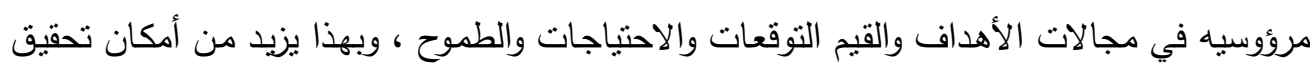

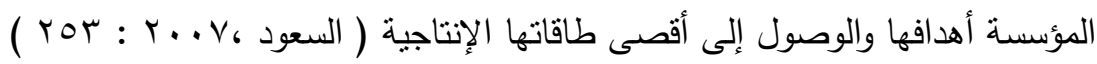


يذكر الثيباني (1910 ) على حاله غير ملموسة ، فلا يمكن مشاهدتها أو ملاحظتها ألا عن

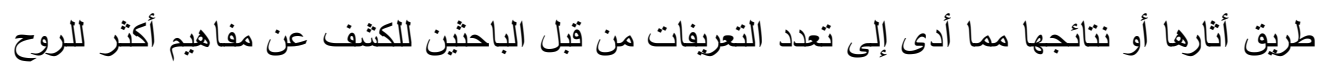

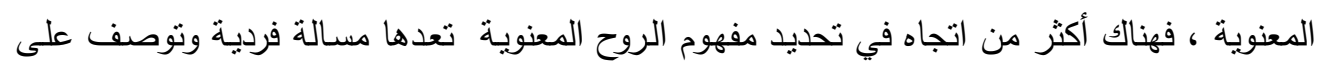

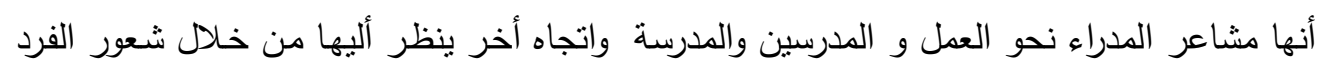

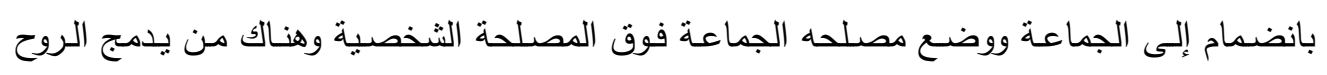

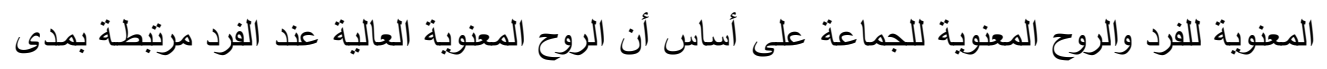

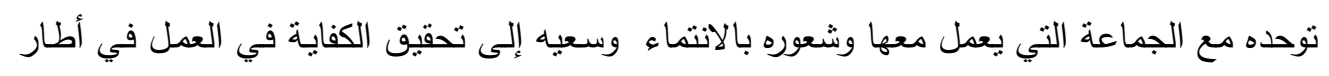

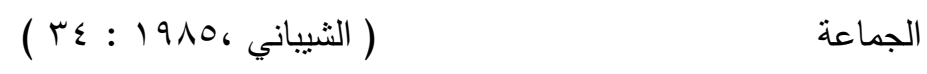

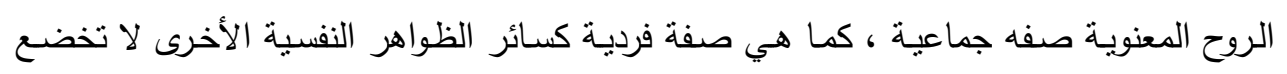
للملاحظة المباشرة فهي تكوين فرضي لا يلاحظ ألا عن طريق أثنارة ونتائجه .

والروح المعنوية مصطلح حديث العهد إذ نشا في الحرب العالمية الأولى ، واخذ الاهتمام بها ينتقل

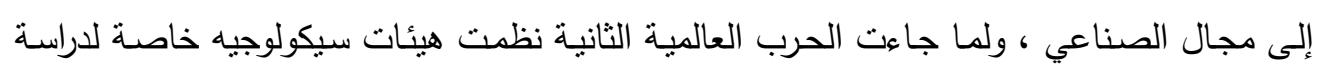

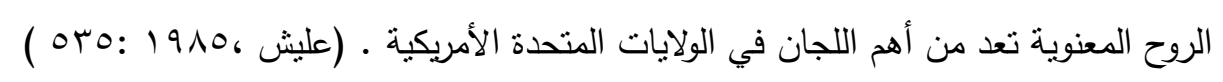

عناصر الروح المغوية : n

تتكون الروح المعنوية على العديد من العناصر منها:

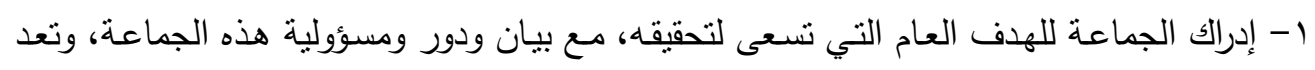

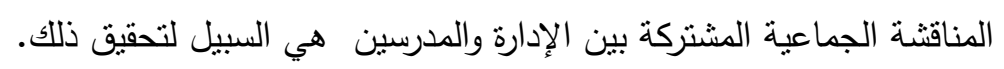

ץ- وجود طرق محكمه للاتصالات المتبادلة بين المدير والمدرسين حتى يفهم كل واحد منهما وجهة نظر الآخر 


\section{العـــــــد الثاني والعشرون}

r- إقامة دوافع العمل وتتظيمها سواء كانت هذه الدوافع مالية أو غير مالية مثل معرفة العمل والرغبة

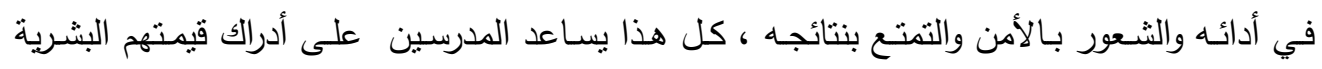

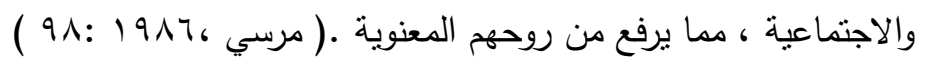

\section{سبل تنمية الروح المعنوية :}

من اجل تتمية الروح المعنوية فلا بد للمدراء العمل الآتي :

ا - إن يشعروا المدرسين بـان جهودهم وأداءهم موضـع التقدير عن طريـق اعتراف الإدارة بأهميـة عملهم إن r- ينبغي أن يجد المدرس في محيط عملة جوا اجتماعيا ممتعا . r- إن يتحرر المدرسين من القلق النفسي وان يشعروا بالاطمئنان على عمهم . ع - إن يتقهم المدرسون سياسات وخطط وأنظمة المدرسة حتى يكونوا على بينه مما يدور حولهم من

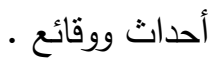

ه- ضرورة تهيئه فرصة التعبير عن النفس لكل مدرس في عملة وإعطاءه فرصة هذا العمل بدرجة

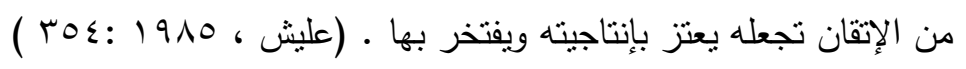

\section{مجالات الروح المغنوية كما وردة في الاستبيان هي:}

1- بعد ظروف العمل : يؤكد محمد ( 1919 ) أن الاهتمام بتوفير ظروف العمل أصبح من الأمور

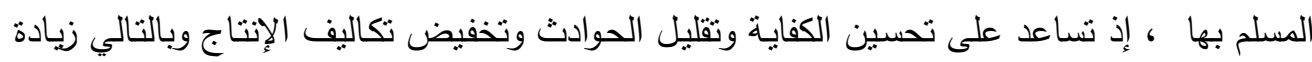

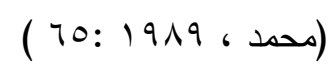

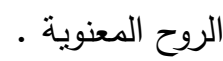

كما ذكر Klawitter, Pamela , 1986 ) ظروف العمل الثروط المادية التي يعمل فيها الدرسين من ضوء وتهويه ونظام فترات العمل والراحة ، فقد يختار المدرس وظيفته اختيار نفسيا 


\section{العـــــــد الثاني والعشرون}

\section{مجلـــة كليـــة التربيـــة}

صحيحا فيوضع في المهمة التي تتاسب الميول والاستعدادات والسمات الانفعالية ( 67 : )

Klawitter, Pamela ,1986

أن مدرسوا المدارس الإعدادية يزداد أخلاصهم وتفانيهم ويتحقق تعاونهم ويعم بينهم الفخر

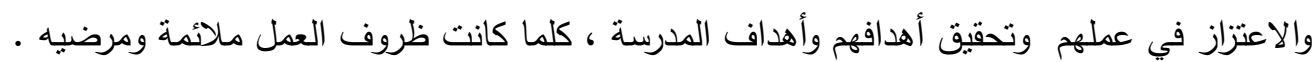

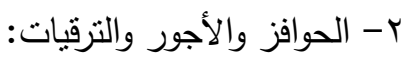

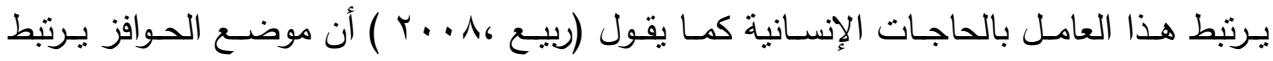

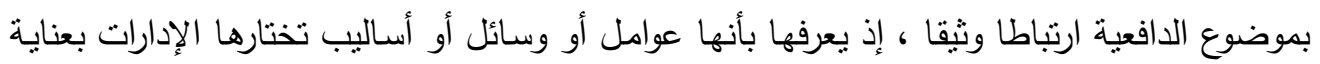

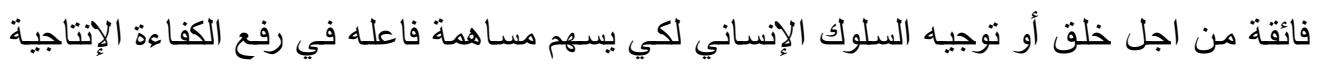

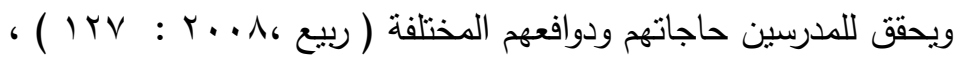

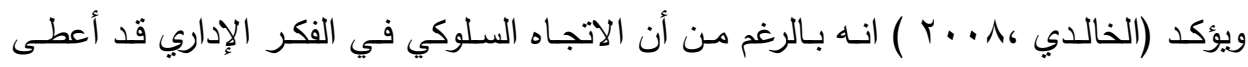

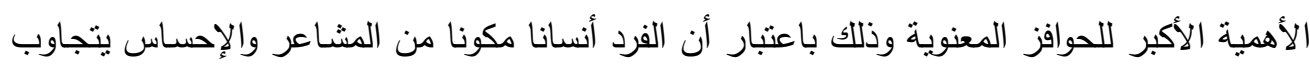

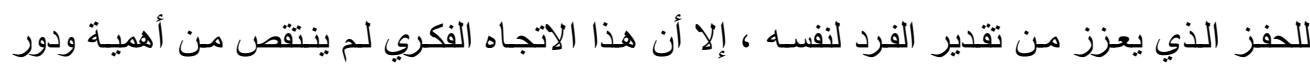

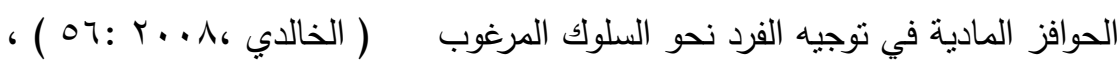

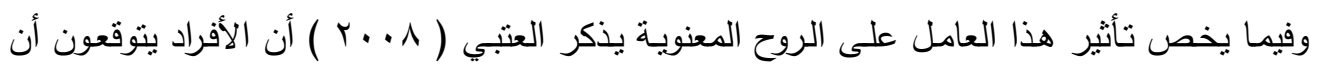

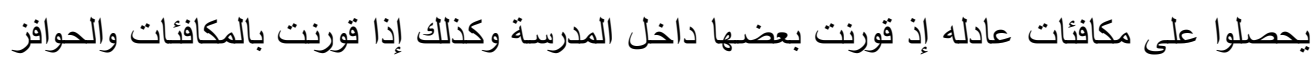

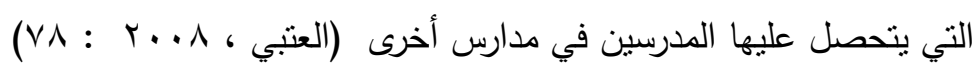

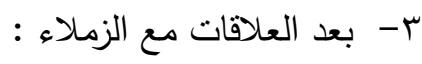

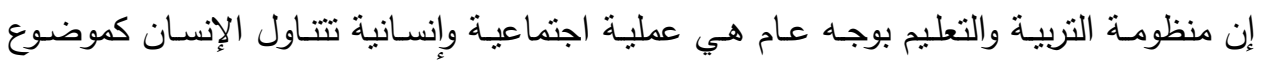

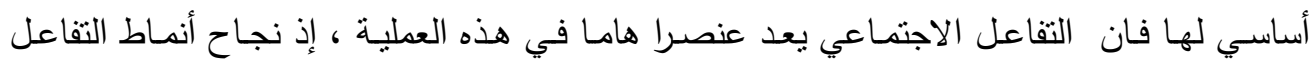

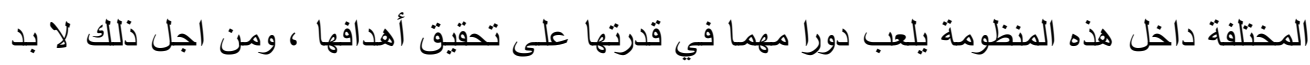

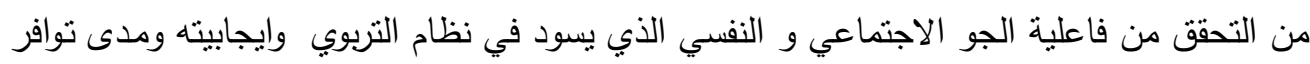

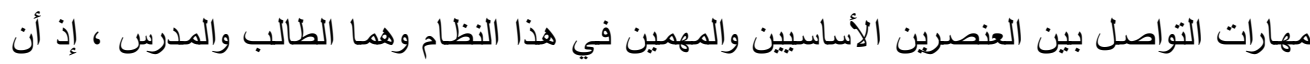




\section{العــــــد الثاني والعشرون}

\section{مجلــــة كليـــــة التربيــــة}

عملية التواصل التعليم تحتاج إلى نوع من المهارات لان المدرس في هذا المجال يتفاعل مـع فئة من

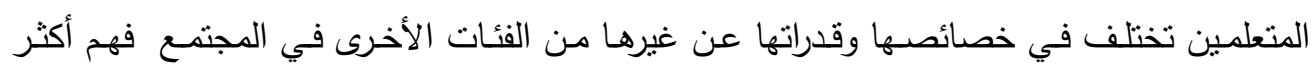
نضجا .( فرج ، 1990 : 199 )

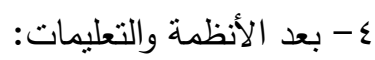

لا يتعامل المدير مـع المدرسين من فراغ ولا تسري عليهم أو بينهم شريعة الغاب ، ولكن هناك نظم وقواعد وسياسات موضوعية مصدرها الإدارات العليا والإدارة المدرسية ، وفي ضوء هذه هذه النظم

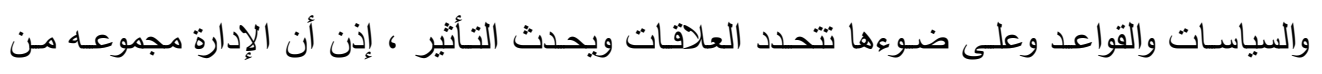

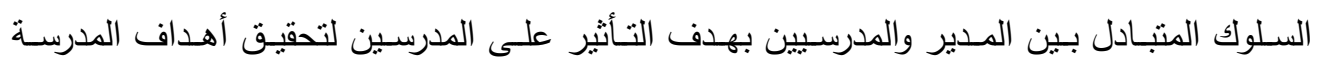
ويستطيع المدير أن يؤثر في المدرسين ، بمعنى أن يدفعهم إلى العمل ولأداء بالأسـلوب والمستوى الذي يرغب فيه باستخدام العديد من الوسائل حسب طبيعة الموقف والذي يستخدم السلطة الرسمية التي يخولها له منصبه (كل مدير له سلطات رسمية منصوص عليها في بطاقة وصف الوظيفة ) أو التأثير في المرؤوسين باستخدام الحوافز المادية أو المعنوية التي ترفع من الروح المعنوية للمدرسين •

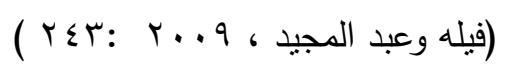
الاراسات السابقة :السلوك الإداري :

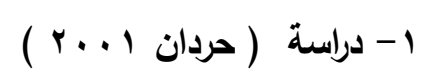

(تصورات مدرسي المدارس الثانوية في محافظتي مسقط وظفار بسلطنة عمان للنمط إلادارة السائد في مدارسهم من وجهة نظرهم ).

هدفت الدراسة التعرف إلى تصورات معلمي المدارس الثانوية لنمط إلادارة السائد في مدارسهم من وجهة نظرهم بـاختلاف الخبرة ، وقد تكونت العينة من ( . .0 ) مدرسٍ ومدرسـة تم اختيارهم بطريقه

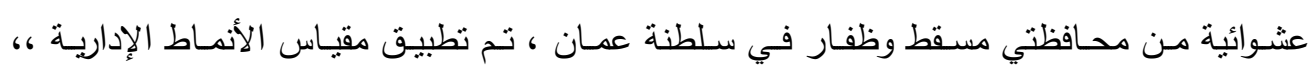

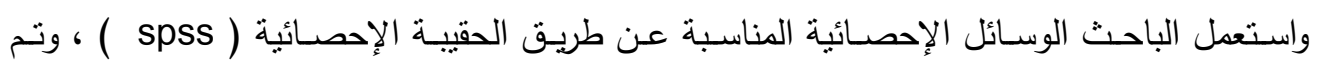




\section{العـــــــد الثاني والعشرون}

توصلت الدراسة إلى أن الأنماط الإدارية كانت مرنبة كلالتي النمط التقليدي والنمط السلوكي النمط الإندان

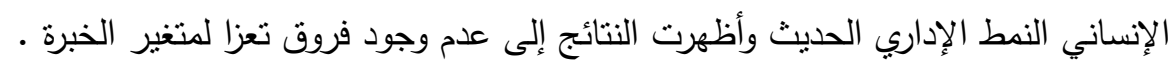

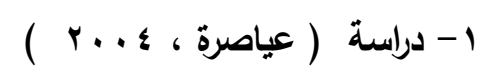

(الأنماط الإدارية لمديري المدارس الثانوية العامة في الأردن )

هدف الدراسـة التعـرف على الأنمـاط الإداريـة السـائدة لـدى مدراء المـارس الثانويـة في الأردن

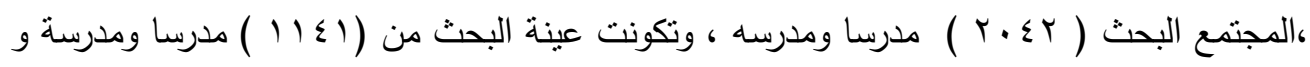

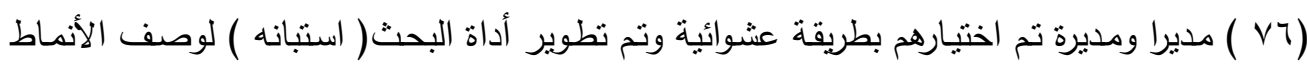

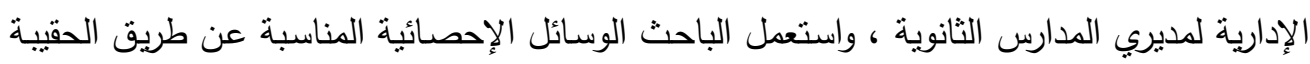

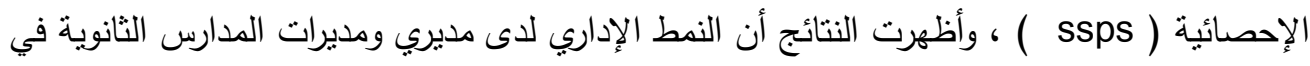

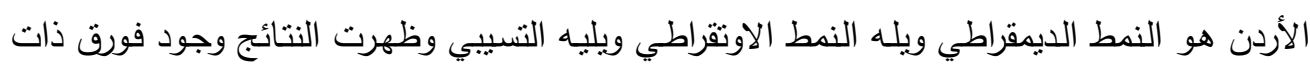

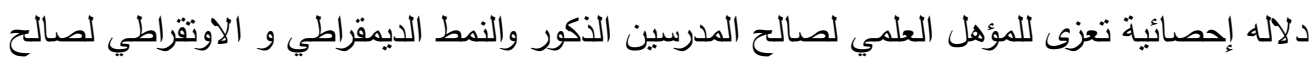

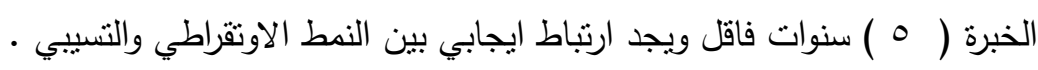

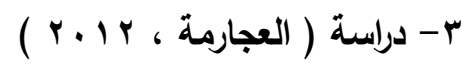

(الأنماط الإدارية السائدة لاى مدراء المدارس الابتدائية الخاصة في الأردن )

هدفت الدراسـة التعرف على الأنماط الإداريـة السـائدة للدى مديري المدارس الابتدائية الخاصـة

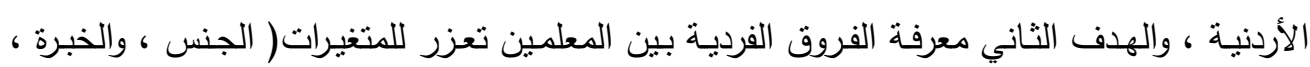

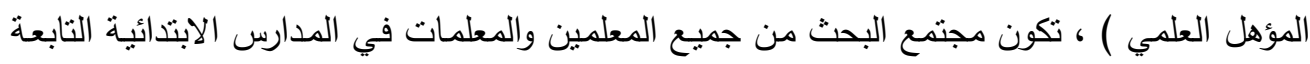

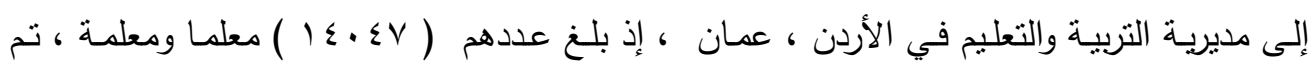

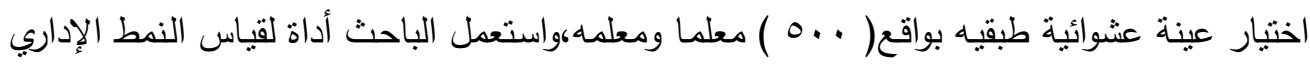

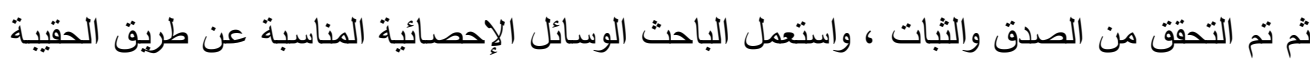

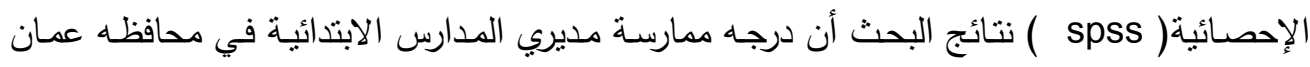

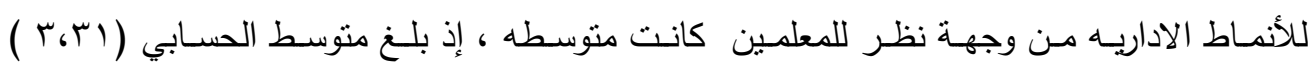


العـــــــد الثاني والعشرون

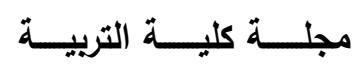

وبانحراف معياري ( V9، · ) وجاء المرتبة الأولى النمط الإداري الاوتقراطي ثم جاء النمط الديمقراطي والنمط المتسـاهل ، وبينت الدراسـة إلى عدم وجـود فروق ذات دلالـه إحصـائية عند مستوى دلالهه (

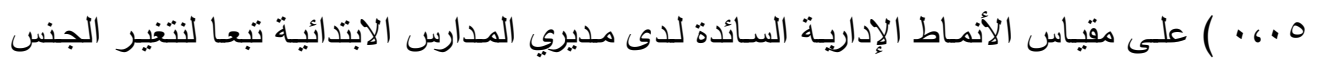
والمؤهل العلمي ، ووجود فروق ذات دلاله إحصائية عند مستوى دلاله ( ه ، . ) على مقياس الأنماط

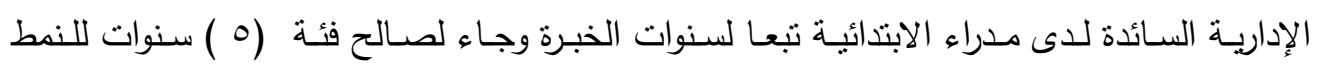
الاوتقراطي ولصالح فئة ( • 1 ) سنوات فأكثر لصالح النمط المنسيب ولصالح فئة ( 0 ) فما دون في

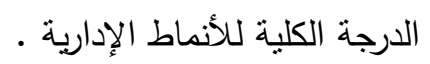

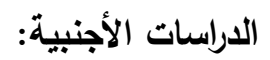

( Dawaln, 1987 ) (راسة )

\section{( The relationship between perception director of Administration style and grasp Amwalimaan to this pattern in northern Ohio US)}

( العلاقة بيلن أدراك المـدير للنمط الإداري وأدراك المعلمين لهذا الـمط في شـمال ولايـة أوهـايو (الأمريكية)

هدف الدراسـة التعرف إلى العلاقة بين أدراك المدير للنمط الإداري وأدراك المعلمين لهذا النمط ، تألفت عينة الدراسة من (Y ) مديرا و • (Y ) ) مدرسا ومدرسه في شمال أوهايو في الولايات المتحدة الأمريكية ، استخدمت أداة الثبكة الاداريه لبليك موتن (Blake Mouton) توصلت الدراسة إلى : ـ عدم وجود نوافق بين أدراك المديرين وبين أدراك المعلمون للنمط الإداري وكان الاتجاه يشير إلى

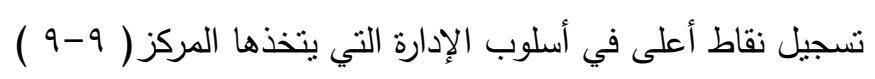

- إن المعلمين أحرزوا في إدراكهم علامات ذو دلالات إحصائية عاليه بيمنا المدراء كانوا أكثر ميلا

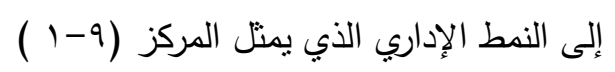


العـــــــد الثاني والعشرون

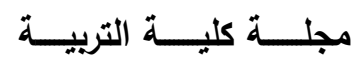

Y Massaro \& Augustus 2000) براسة

(النمط القيادي لمدير المدرسة وأدراك المعلمين لمدير مدرستهم )

\section{( Teacher percent of school climate self and princiported leaderships tylebased)}

هدفت الدراسة إلى اختبار العلاقة بين النمط القيادي لمدير المدرسة وأدراك المعلمين للنمط القيادي

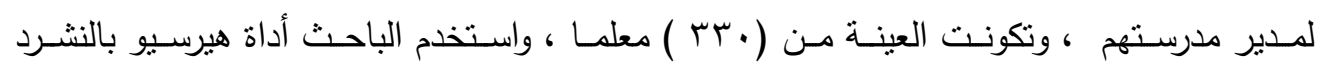

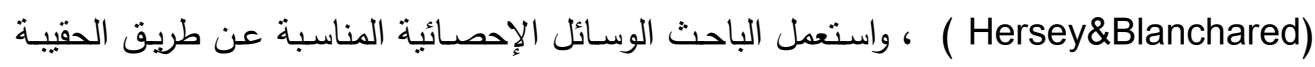
الإحصائية( spss ) ، وكانت ابرز النتائج الني توصلت أليها الدراسة هي:

أكدت النتائج أن المديرين والمعلمين يعملون بشكل تعاوني بهدف تحسين الاتصال بينهم ، وأوصت

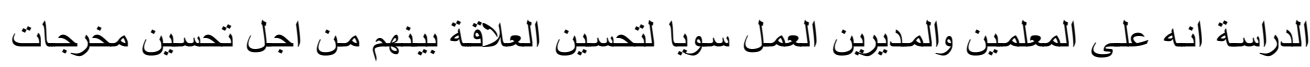
المدرسة الأسة النه

دراسات سابقه الروح المعنوية :

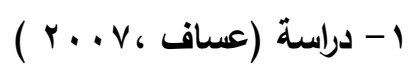

( الروح المعنوية مستواها ومصادرها ومجالاتها لدى معلمي ومعلمات المرحلة الأساسية في مدينة نابلس الفلسطينية )

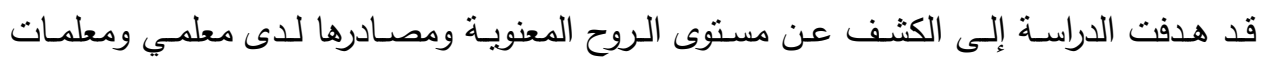

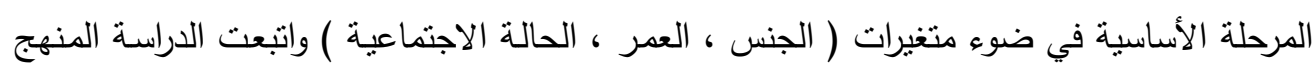

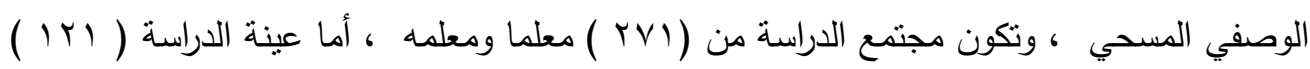

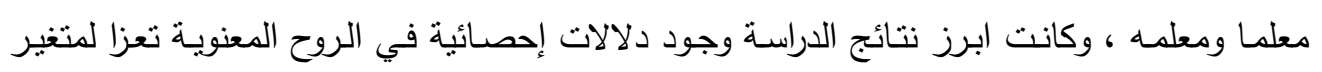


العـــــــد الثاني والعشرون

\section{مجلــــة كليـــــة التربيــــة}

جنس المعلم ، إذ تبين أن للمعمين روح معنوية اعل من المعلمات ، بينما لا توجد فروق ذو دلاله

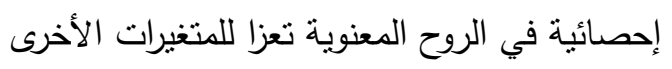

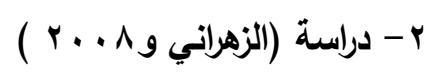

\section{(الروح المعنوية لمعلمات المرحلة الابتدائية في محافظة جده في السعودية )}

هدفت الدراسـة التعرف على الروح المعنويـة لمعلمات المرحلة الابتدائية في جده ، وتكون مجتمـع

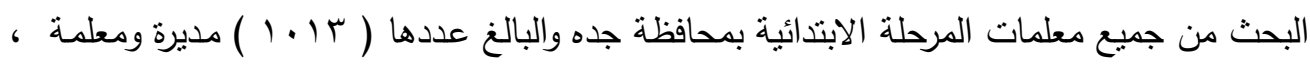
وقد استخدم الباحث المنهج الوصفي ، واستعمل الباحث الوسـئل الإحصـائية المناسبة عن طربيق الحقيبـة الإحصـائية( spss ) ، وابرز نتائج هذه الدراسـة وجود علاقـة ارتباطيـة موجبـه بين النمط القيادي والروح المعنوية من وجهت نظر المديرات في المدارس الحكومية عند مستوى دلاله ( +.، . ) ، إذ بلغ معامل الارتباط سبيرمان بين النمط الديمقراطي والروح المعنوية (r V، . ) )

(- دراسة ( Carroll , 1993)

\section{( Morale Malmyin in Primary schools )}

\section{( الروح المعنوية للمعلمين في المدارس الابتدائية )}

هدفت الدراسة الترف على الروح المعنوية للمعلمين في المدارس الابتدائية والتي شملت الصفوف

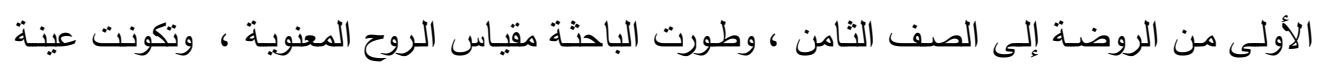

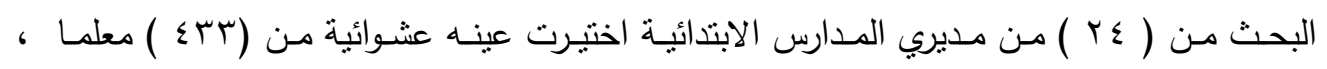
واستعمل الباحث الوسـائل الإحصـائية المناسبة عن طريـق الحقيـة الإحصـائية ( spss ) ، وقيد أثنارت نتائج الدراسة إلى وجود علاقة ايجابيه للروح المعنويـة فالروح المعنوبية كانت مرتبطة بالسلوك الإسيه القيادي للمدراء . 
r- Martin,2000 ( دراسة

(Morale Malmyin in Primary school in Hampon County Virginia )

( الروح المعنوية للمعلمين في المدارس الابتدائية في مقاطعه هامبتون في ولاية فرجينيا )

هدفت الدراسة التعرف على الروح المعنوية للمعلمين في الددارس الابتدائية في مقاطعة هامبتون في

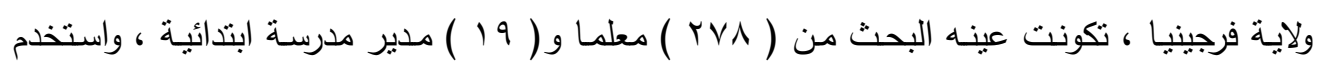

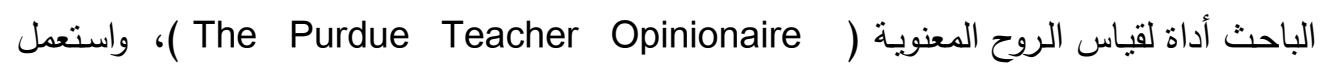
الباحث الوسائل الإحصائية المناسبة عن طريق الحقيبة الإحصائية ( spss ) ، وقد أثنارت نتائج

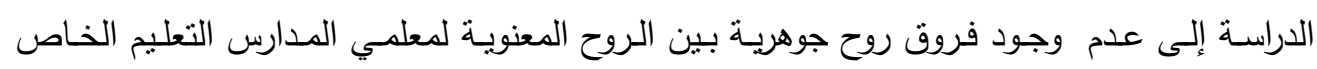

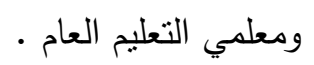


من اجل تحقيق أهداف البحث الأساسية فقد تطلب التعرف على المجتهع الأصلي واختيار عينة البحث وتحديد الخطوات التي اتبعت في بناء أداتا البحث والإجراءات التي اتبعت في جمع البيانات والوسائل الإحصائية المناسبة التي استخدمت في معالجتها والتوصل إلى النتائج المطلوبة .

: منهج البحث : n

تم استعمال المنهج الوصفي ألارتباطي لتوضيح العلاقة بين أنماط السلوك الإداري وفقا لنظريـة رنسيس ليكرت ( نظـام1- نظـام4 ) للدى مديري المدارس الإعداديـة وعلاقته بـالروح المعنويـة •للمدرسين

\section{مجتمع البحث :}

يتكون مجتمع البحث من جميع المدرسين والمدرسات في المدارس الإعدادية التابعين إلى المدرية العامة لتربية واسط في مركز قضاء الكوت والبالغ عددهم ( ؟9 7 ) مدرساً ومدرسة بواقع ( ذكور و (q ب ) إناث ، والثكل (

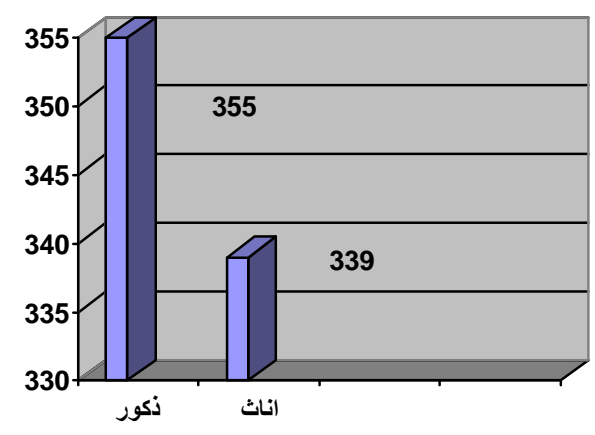

الثكل ( 1 ) يبين التمثيل البياني لمجتمع البحث . 


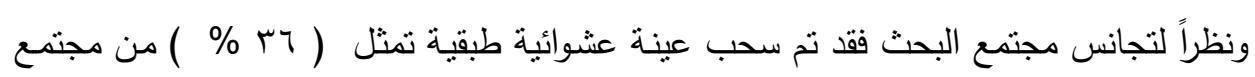

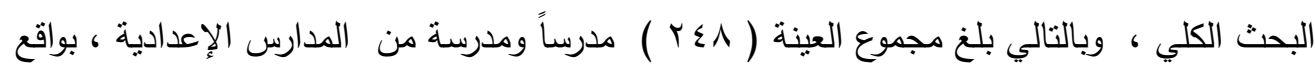

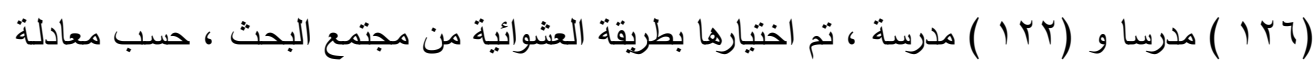

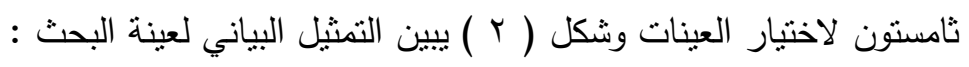

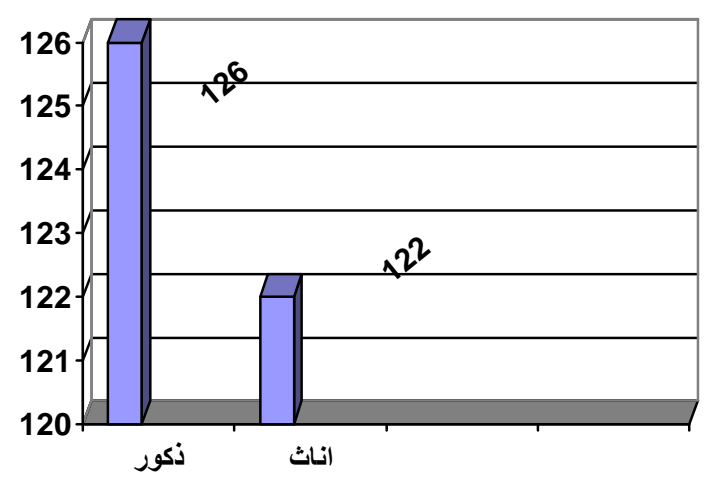

شكل ( r r ) يبين التثنيل البياني لعينة البحث

أداتا البحث : n (n) تكونت أداتا البحث من مقياسين هما :

أولا: السلوك الإداري وهو استبانه تتكون من مجموعة من الفقرات لقياس السلوك الإداري ، ويتكون

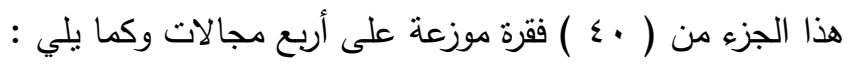
1- النمط الاستشاري الديمقراطي ويتكون من (•1 ) فقرات r- النمط التشاركي الديمقراطي : ويتكون من (• ( ) فقرات 


\section{العـــــــد الثاني والعشرون}

\section{(II) \\ r- النمط الاستبدادي الخير: ويتكون من (• ( ) فقرات \\ ـ - النمط الاستبدادي التسلطي : ويتكون من ( • ( ) فقرات}

ثانيا : الروح المعنوية : وهي استبانه تتكون من مجموعه من الفقرات لقياس الروح المعنوية ويتكون هذا الجزء من ( r T ) فقرة موزعه على أربع مجالات وكما يلي :

1- بعد العلاقات مع الزملاء : ويتكون من (1 ) فقرات

r- بعد الحوافز والأجور والترقيات : ويتكون من (1 ) فقرات

ب- بعد ظروف العمل : ويتكون من (^ ) فقرات

ع - بعد الأنظمة والتعليمات : وتتكون من ( A ) فقرات

Face Validity : صدق الأداة

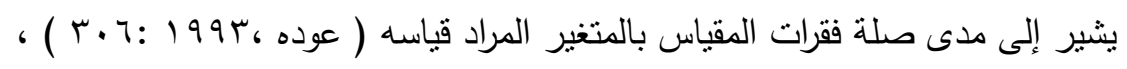

ويشر "Ebel" إلى أن الوسبلة المفضلة للتأكد من الصدق الظاهري لأداة القياس هي أن يقوم عدد

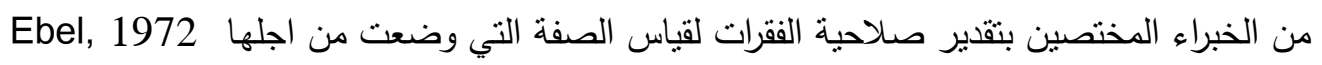

وقد تحقق ذلك من خلال عرض الاستبانة على مجموعه من الخبراء المختصين في التربية وعلم

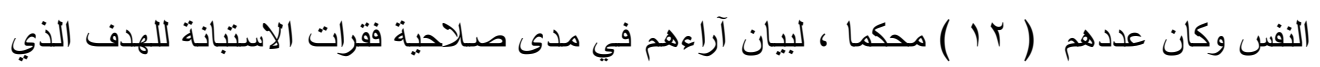

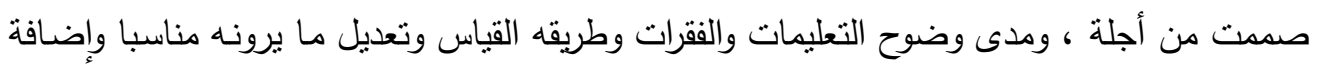

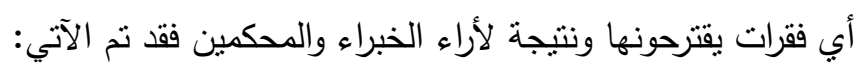

1 - قبول الفقرات التي اتفق عليها (،^\% ) من السادة الخبراء أنها تقيس ما تهدف إلى قياسه . ץ- استبعاد الفقرات التي لا تحصل على نسبة ( •^ \% ) فأكثر. 


\section{العـــــــد الثاني والعشرون}

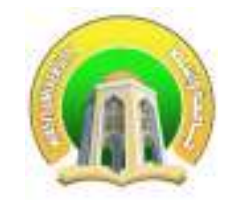

\section{مجــــة كليــة التربيــة}

r- تم تعديل وإعادة صياغة بعض الفقرات واجمع المحكمين والخبراء على وضوح التعليمات وطريقة

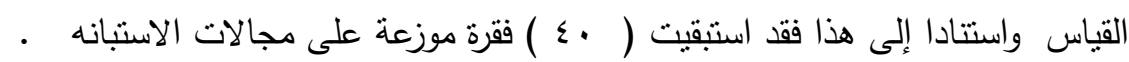

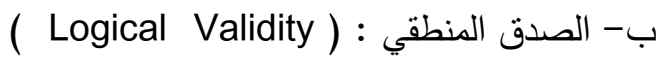

هو يعبر على قدرة المقياس على قياس مجال محدد من السلوك والذي ينحقق من التعريف النظري

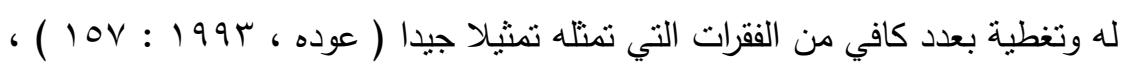
وقد نوافر هذا النوع من الصدق من خلال تحديد المجال وتغطية بعدد كافي من الفقرات التي اثبت

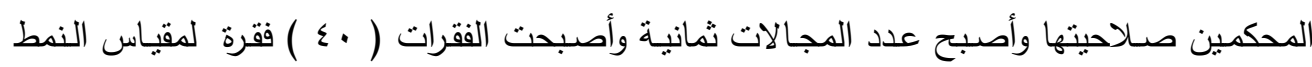
الإداري موزعه على أربع مجالات والجدول الآتي يوضح ذلك :

\section{الإجراءات الإحصائية لتحليل فقرات مقياس السلوك الإداري:}

يعد تحليل الفقرات إحصائيا من المتطلبات الأساسية لبناء المقاييس التربوية والنفسية كون التحليل

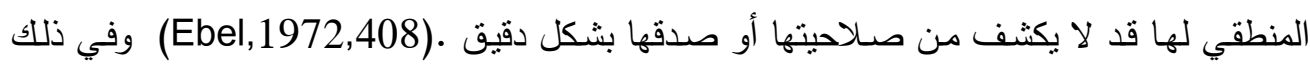

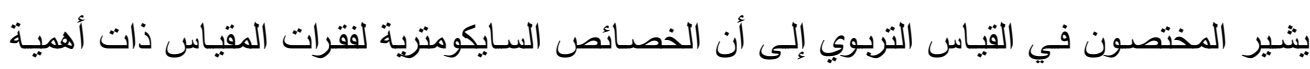
كبيرة في قدرتها على قياس ما وضعة لقياسه ، ومن هذه الخصائص الصدق والثبات التصائل اللتان تعنمدان

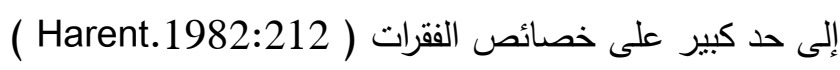

- القوة التمييزيـة للفقرات : من اجل الكثف عن الفقرات المميزة والفقرات غير المميزة تم تحليل

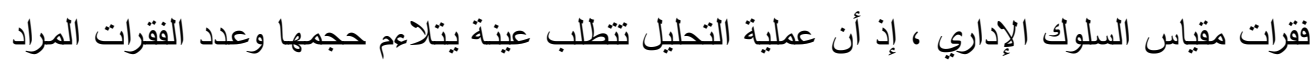

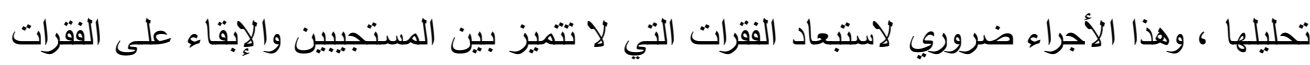

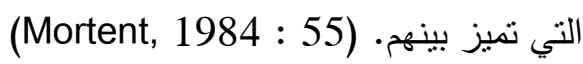

ويمكن أن تعد القوة التمييزيـة للفقرات ومعاملات صدقها من أهم الخصـائص القياسية التي نبغي القيا

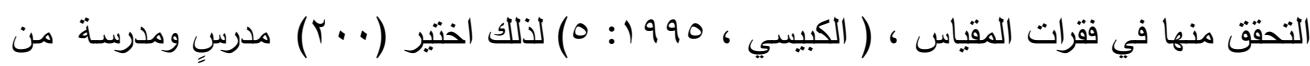
خارج عينة البحث وطبق المقياس على العينة المذكورة باستعمال الأسلوبين الآتيين: 
ا - أسلوب المجموعتين المتطرفتين :

لمعرفة القوة التمييزيـة للفقرات رتبـت الدرجات الكليـة التي حصل عليها أفراد العينـة بعد تصـحيح

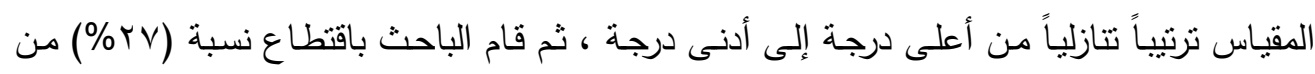

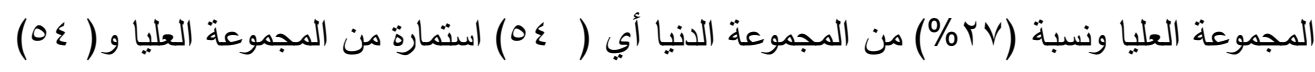
من المجموعة الدنيا

وذلك لإخضاعها إلى العملية التحليل الإحصائية للحصول على أقصى درجات التطرف في الاستجابة بين المجموعتين ، وتم حساب الوسط الحسابي والاتحراف المعياري للمجموعة العليا والوسط الحسابي والانحراف المعياري للمجموعة الدنيا على فقرات المقياس والبالغ عددها ( ع) فقرة ، وتم تطبيق الاختبار التائي لعينتين مستقلتين للتعرف على دلالة الفرق بين المجموعة العليا والمجموعة الدنيا على ،لى وفق كل فقرة ، ثم مقارنة القيمة التائية المحسوبة بالقيمة التائية الجدولية والحكم على درجة تمييز

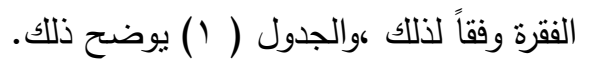


العـــــــد الثانـي والعشرون

\section{جدول( )}

أوساط الحسابية والاتحرافات المعيارية الخاصة بفقرات مقياس السلوك الإداري والقيمة التائية المحسوية الدالة على تمييز فقرات المقياس

\begin{tabular}{|c|c|c|c|c|c|}
\hline \multirow{2}{*}{ القيمة التائبة } & \multicolumn{2}{|c|}{ المجموعة الدنيا } & \multicolumn{2}{|c|}{ المجموعة العليا } & \multirow{2}{*}{ رقم } \\
\hline & الانحراف المعياري & متوسط الحسابي & الانحراف المعياري & متوسط الحسابي & \\
\hline V.OTN & $1 . \Sigma Y \backslash 1$ & Y.E.VE & .99194 & $\varepsilon .1$ 1 O & 1 \\
\hline T.rNI & ו וצTYK & 5.1111 & ..vqr.o & $\varepsilon .0007$ & r \\
\hline$\varepsilon .0 \vee 0$ & 1. & r.9110 & זדונו1. & $\varepsilon . r \leq \cdot V$ & $r$ \\
\hline ו.人ץ & 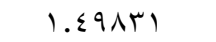 & r.9A10 & $. V \leqslant 01 r$ & E.orV. & $\varepsilon$ \\
\hline $0 . . V 7$ & $1.7 \vee 77$. & $r .9110$ & $1 . .9 q 9$ & אזrז.E & 0 \\
\hline $7 . \leqslant \leqslant 0$ & $1.001 . r$ & אسזی.ץ & $.9 \leq \leq 10$ & $\varepsilon . \leq \leq \leq \leq$ & 7 \\
\hline$\leq . V) \leq$ & 1.107 .7 & 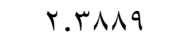 & I. & r.0110 & V \\
\hline$r .9 \leq 7$ & 1. sovor & r.7rq7 & $1 . \leqslant 7 \wedge 99$ & $r . V \leq \cdot V$ & $\wedge$ \\
\hline Q.YTV & $1 . \Sigma Y \backslash 1$ & Y. $\Sigma \cdot V \varepsilon$ & .9 rova & E.orV. & 9 \\
\hline $0.0 \leqslant 1$ & $1 . r 9 \wedge \varepsilon \varepsilon$ & r. $7 \wedge \circ \mathrm{r}$ & I.rTHVI & $\varepsilon .997$ & 1. \\
\hline V.ror & $1 . \Sigma 70 V \wedge$ & r.vo9r & $.9 \leq 701$ & $\varepsilon . \leqslant \wedge 10$ & 11 \\
\hline 7.ro. & $1.511 \wedge 7$ & Y.M & 1.1178. & r.AV. $\varepsilon$ & Ir \\
\hline 7.901 & דrאו1.1 & r.I rq4 & . Av017 & E.7ץq7 & r \\
\hline 7.901 & דrאגו1 & r.I r9ד & ו ו & $\Gamma . \wedge) \leq \wedge$ & $1 \leqslant$ \\
\hline r. .А^ & $1.7 \cdot \varepsilon \cdot V$ & r.ı roqr & $1.1 r+90$ & $\varepsilon .0097$ & 10 \\
\hline $0.0 \leqslant 0$ & 9ז7 1.01 & r.vo9r & $1 . r . \vee q \varepsilon$ & E.TYYT & 17 \\
\hline 7.7 Yo & $1.01 \% .0$ & Y.0007 & $1.9 \cdot V V V$ & $\varepsilon . r \leq \cdot V$ & IV \\
\hline V.70r & $1.11 \leq 99$ & Y.r $\mid \leqslant \wedge$ & $1 . r \leq 97$. & $\varepsilon . r . r V$ & 11 \\
\hline 1.947 & $1 . \Sigma Y \backslash 1$ & Y. $\Sigma \cdot V \leqslant$ & $.9 \leq 701$ & $\varepsilon . \Sigma \wedge 10$ & 19 \\
\hline $7.7 V T$ & $1 . \leqslant \vee q \leq r$ & Y.T74V & $.9 \vee 90 r$ & $\varepsilon . Y \vee \vee \wedge$ & $r$. \\
\hline $0 . \varepsilon r \varepsilon$ & 1.0 .49$. & r.VVVA & $.9 \leq \Lambda V T$ & $\varepsilon \ldots . v \leq 1$ & YI \\
\hline 7.719 & 1.71119 & $r . . v \leq 1$ &.$\vee Y \neg \wedge \varepsilon$ & צד. & r \\
\hline צדיט & $1.5 \vee 017$ & Y.VVVE & 1. $r \vee q \leq \varepsilon$ & $\varepsilon . Y \cdot T V$ & rr \\
\hline
\end{tabular}


العـــــــد الثاني والعشرون

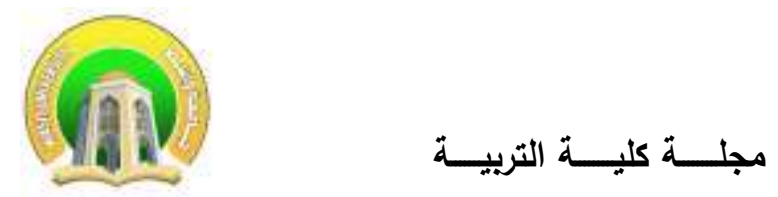

\begin{tabular}{|c|c|c|c|c|c|}
\hline$\varepsilon .77 V$ & $1.01 r .0$ & $r .1111$ & 1.9901 & E.r97 & $r \varepsilon$ \\
\hline r.. rq & $1.77 \varepsilon \cdot \varepsilon$ & $r . r \cdot r v$ & 1.1 & $\varepsilon .+r V$. & ro \\
\hline 0.101 & $1 . r \leq \wedge \leq 0$ & $r . V \leq \cdot V$ & $1 . r 4 \ldots \varepsilon$ & E.110r & r \\
\hline 纟.YqV & .09194 & r.ro19 & $1 . .9 \leq \leqslant r$ & $\varepsilon . \varepsilon \wedge 10$ & $r V$ \\
\hline 9.0 .1 & $1 . \varepsilon \leqslant \leqslant$ or & r.rV. $\varepsilon$ & $\cdot 9 \cdot$ r人t & $\varepsilon .0 V \leqslant 1$ & $r \wedge$ \\
\hline T.VT. & $1.09 \times 19$ & r.sY०q & $1 . r V \leqslant q r$ & E.l10r & $r q$ \\
\hline 纟.Ar. & 1.7TrVA & r...9rד & $1 .+1 \leq 91$ & $\varepsilon . V \mu \cdot \varepsilon$ & r. \\
\hline 7.901 & 1.1אזrא & r.I Y 97 & I.THA & $r . \wedge I \leqslant \Lambda$ & M \\
\hline r.911 & $1.7 \cdot \varepsilon \cdot V$ & r.lroqr & $1.1 r r 90$ & $\{\ldots .0097$ & rr \\
\hline $0.0 \leq 0$ & 1.01749 & r.vo9r & $1 . r \cdot V 9 \leq$ & E.TYTY & سז \\
\hline $7.7 r o$ & $1.01 r .0$ & r.0007 & $1.9 \cdot v V V$ & $\varepsilon . r \varepsilon \cdot V$ & $r \varepsilon$ \\
\hline V.70r & $1 . r 1 \leq 99$ & r.rI $\leq \Lambda$ & $1 . r \leq 97$. & E.r.TV & ro \\
\hline N.9r7 & $1.8 Y 11$ & Y.乏.V $\varepsilon$ & $.9 \leq 701$ & $\varepsilon . \leqslant \wedge 10$ & דr \\
\hline $7 . T V Y$ & $1 . \leqslant V 9 \leq r$ & T.747V & $.9 \vee 90 r$ & E.rVVA & rv \\
\hline $0 . \leqslant T \leqslant$ & 1.0 .49 & r.VVVA & $.9 \leq \Lambda V Y$ & $\leq . \cdot V \leqslant 1$ & ro \\
\hline 7.719 & 1.71119 & $r . . v \leq 1$ & .VYTA & ะ.าง & rq \\
\hline 0.174 & $1.5 \vee 017$ & T.VVVE & 1. YVq & E.r.TV & $\varepsilon$. \\
\hline
\end{tabular}

ومن خلال الجدول يتبين أن جميع فقرات المقياس والبالغة ( • ع) فقرة دالة إحصائيا ومميزة

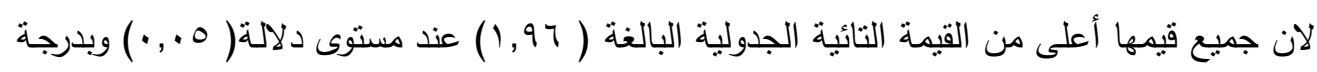
حرية (1) 
( Reliability ) : الثبات

يعد مفهوم الثبات من المفاهيم الأساسية في القياس ويجب نوافرها في المقياس لكي يكون صالحا

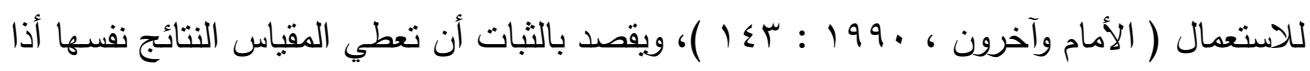
ما أعيد تطبيقه على الأفراد أنفسهم وفي الظروف نفسها ، كما أن الثبات يعني الاتساق في نتائج

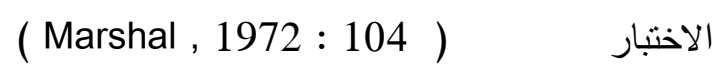

ولاستخراج ثبات الأداة عدة أساليب منها التجزئة النصفية ، أعادة الاختبار ، الصور المتكافئة ،

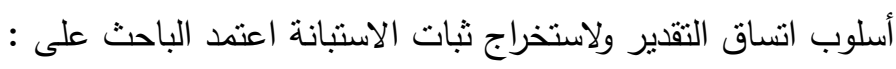

طريقتن هما : طريقة الاختبار و أعاده الاختبار ( Test-r test ) بتوزيعها على (•r)

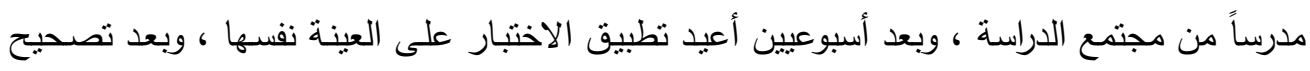

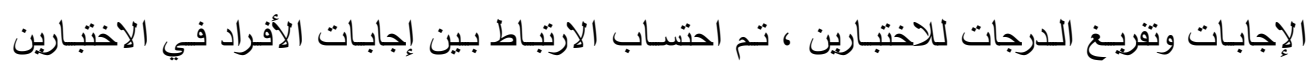
باستعمال معادلة ارتباط بيرسون ومعامل انساق الداخلي ( الفا كرونباخ ) (Cronbach Alpha )

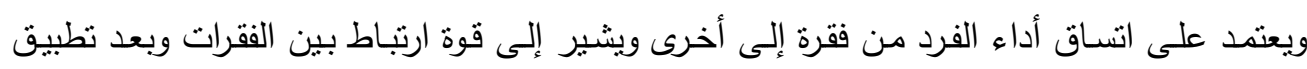

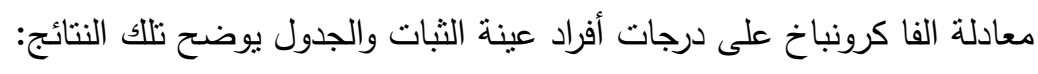

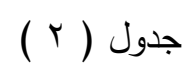

قيم معاملات الثبات لأداتي الدراسة حسب طريقة الاختبار وإعادة الاختبار ولاتساق الداخلي ( الفا

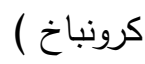

\begin{tabular}{|c|c|c|}
\hline أداة الروح المعنوية & أداة النمط الإداري & الطريقة \\
\hline 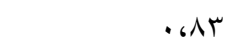 & . ، & الاختبار واعادة الاختبار \\
\hline $.6 \mathrm{~V}$ & .699 & الاتساق الداخلي (الفا ) \\
\hline
\end{tabular}




\section{العــــــد الثاني والعشرون}

\section{مجلـــة كليـــة التربيـــة}

يتضح من نتائج الجدول ( r r ) أن أداة البحث تتمتع بقيم معاملات ثبات مقبولة لإغراض

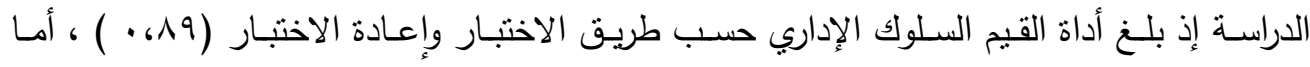

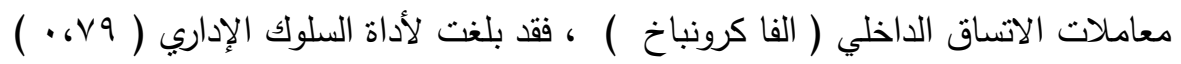
ثانيا : الروح المعنوية :

لغرض تحقيق أهداف البحث وبعد الرجوع إلى الأدب النظري فقد اعد الباحث أداة الروح المعنوية ، وفيما يلي وصف خطوات بناء الأداة .

1- قام الباحث بنوجيه سؤال مفتوح إلى عينه من الددرسين وقد حصل الباحث على استجابات منعددة

r- وفي ضـوء الاستجابات التي سبق صـاغ الباحث مجموعـه مـن الفقرات التي تمثنل أداة الروح المعنوية لدى المدرسين ، كما روعيت في صياغة الفقرات المقومات السايكومترية التي تحكم تصميم

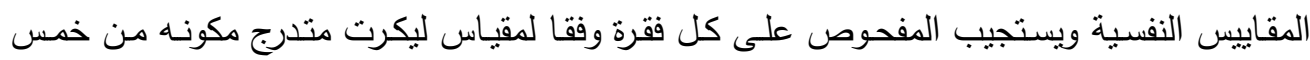

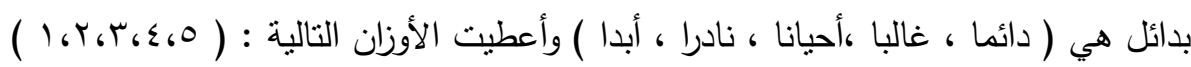

r- صدق الأداة عرضت الصورة الأوليـة للأداة على مجموعة من الخبراء والمحكمين من اسـاتذه

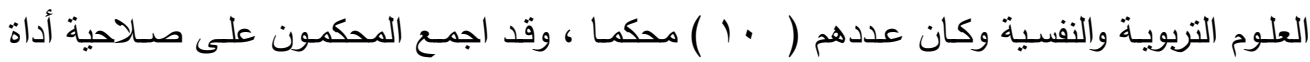
البحث ، أنها تقيس ما وضعت لقياسه بعد أجراء التعديلات اللغوية .

حُسب ثبات الأداة بطريقه أعادة الاختبار بعد أسبوعيين من النطبيق الأول على عينه مكونه من

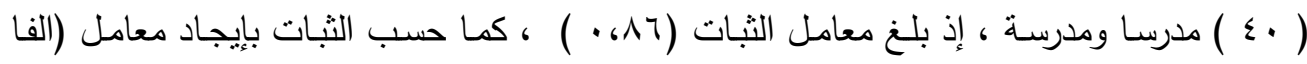

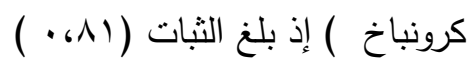


العــــــد الثاني والعشرون

\section{مجلـــة كليـــة التربيـــة}

ع - تصحيح الأداة يسمح المقياس بوضع درجة لاستجابة كل مفحوص على كل فقرة من فقرات

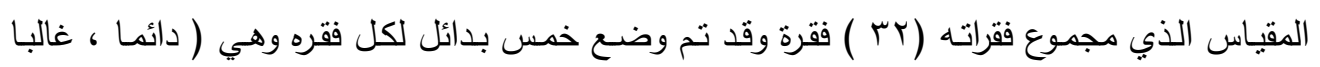

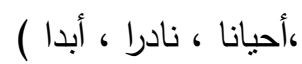

، واستخرج الدرجة الكلية عن طريق جمع درجات الاستجابات على المقياس لكل مفحوص وقد

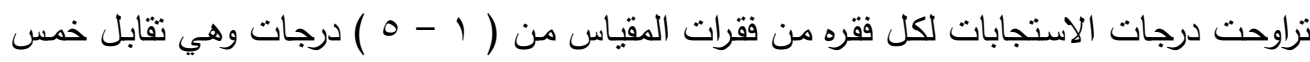

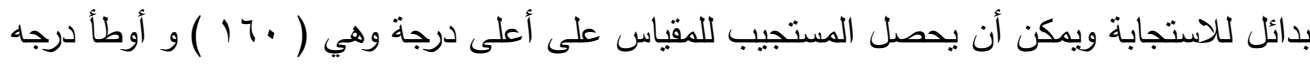

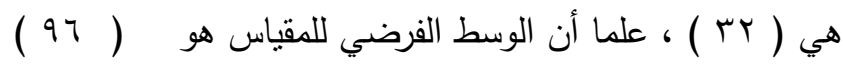




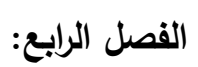

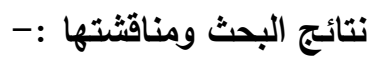

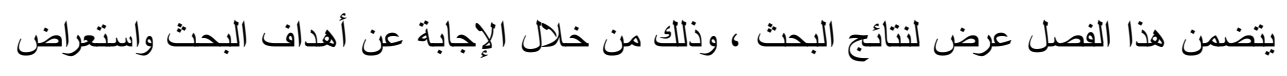

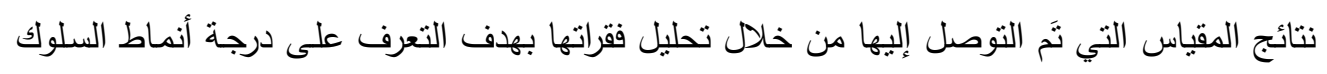

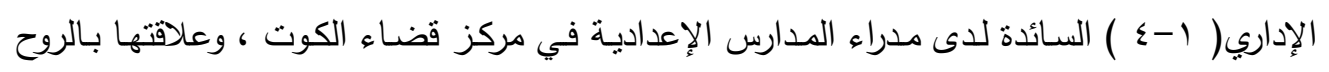

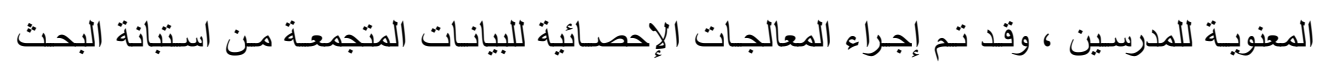

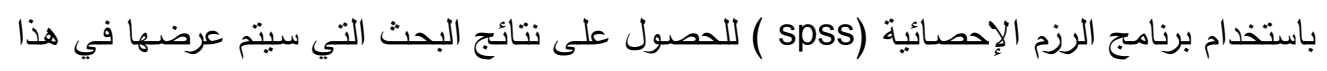

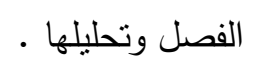

الهلف الأول :الكثف على درجة السلوك الإداري لمدراء المدارس الإعدادية وفقا لنظريـة فرنسيس ليكرت نظام (1- (1) )

تحقيقا لهذا الهذف تم تطبيق مقياس السلوك القيادي وفقا لنظرية فرنسيس ليكرت نظام (1-ـ )

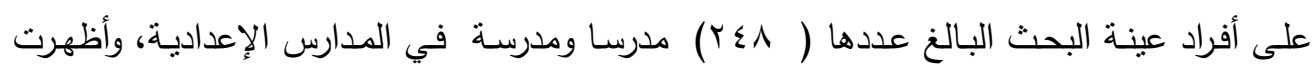

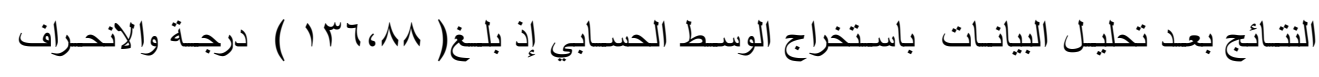

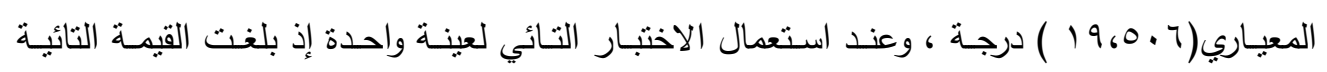

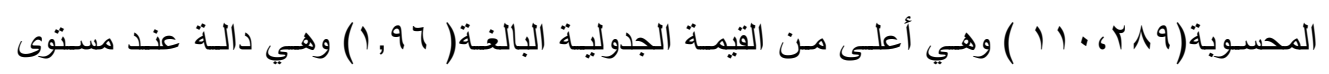

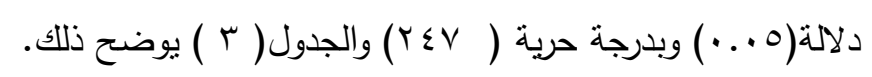

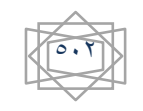




\section{جدول(r )}

الاختبار التائي لعينة واحدة One Sample Statistics T- test لمقياس السلوك الإداري

للمدراء

\begin{tabular}{|c|c|c|c|c|c|c|c|}
\hline \multirow{2}{*}{ مستوى الدلالة } & \multicolumn{2}{|c|}{ القيمة التائية } & \multirow{2}{*}{ الفرضي } & \multirow{2}{*}{ الانحراف المعياري } & \multirow[t]{2}{*}{ الوسط الحسابي } & \multirow{2}{*}{ عدد } & \multirow[t]{2}{*}{ المتغير } \\
\hline & الجدولية & المحسوبة & & & & & \\
\hline دالة & 1,97 & $11.64 \wedge 9$ & & 1960.7 & $1 \pi 4, \lambda 1$ & $r \leqslant \wedge$ & 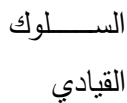 \\
\hline
\end{tabular}

هذه النتيجة تثير أن مديري المدارس الإعدادية لهم دور في أتباع الأنماط الإدارية وفقا لنظرية

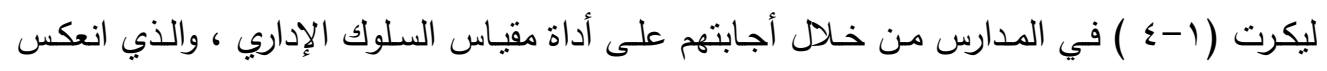
بدورة على بناء المناخ التعليمي المناسب وبث روح الحماس في نفوس المدرسين والطلبة ونتجيعهم ، والابتعـاد عن الأسـاليب التسلطية التي لا تؤدي إلى تتميـة وتحقيـق الروح المعنويـة للمدرسين في

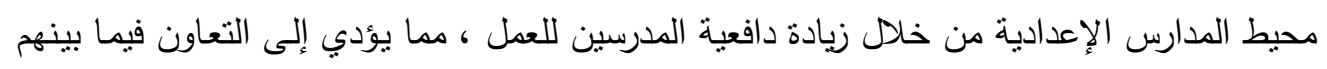

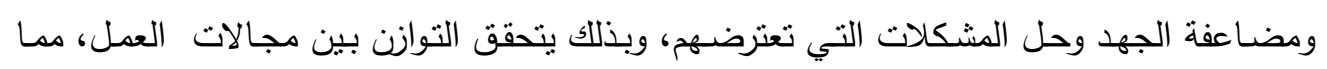
يجعل العملية التعليمة تسير وفق أحسن وجه ممكن ، وهذه من وظائف المدير الناجع.

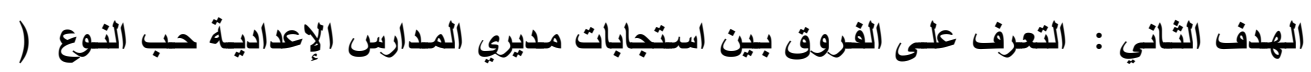
ذكر- أنثى ) و سنوات الخدمة ( من ه ه - . سنوات ، وأكثر من · 1 سنوات ) 


\section{العـــــــد الثاني والعشرون}

\section{مجلـــة كليـــة التربيـــة}

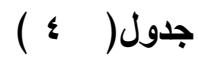

يبين الأوساط الحسابية والانحرافات المعيارية للسلوك الإداري وفق نظرية ليكرت (1- ) ) حسب

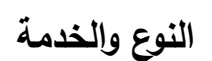

\begin{tabular}{|c|c|c|c|c|}
\hline العينة & الانحراف المعياري & الوسط الحسابي & الخدمة & النوع \\
\hline$\leqslant 9$ & $\left|V_{0} \leq \varepsilon\right|$ & $1 \leq .691$ & من 0- ، 1 سنوات & \\
\hline VV & 18.949 & 154.99 & أكثر من • ا سنوات & \\
\hline 1 MT & IV.VVT & $1 \mathrm{r} \Lambda_{6} 0 \leqslant$ & & المجموع \\
\hline$\sum V$ & 19.09. & gr.94 & من ه- . ا سنوات & \\
\hline vo & Y1.979 & $14_{1} \cdot . v$ & أكثر من · ا سنوات & \\
\hline ITr & rla.,ro & ITOGKT & & المجموع \\
\hline
\end{tabular}

وسيتم مناقشة السلوك الإداري وعلى النحو الآتي :

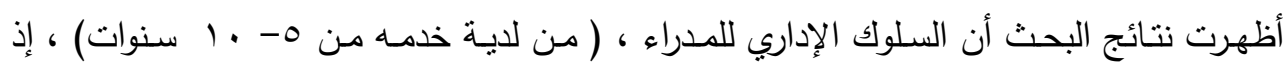

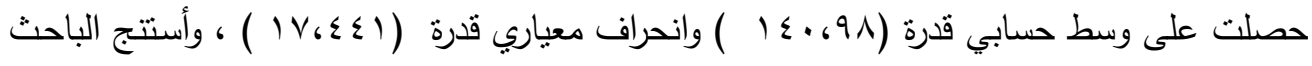

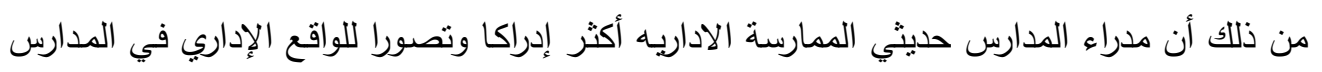

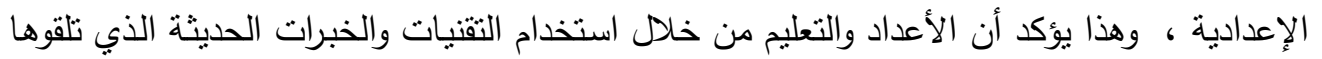

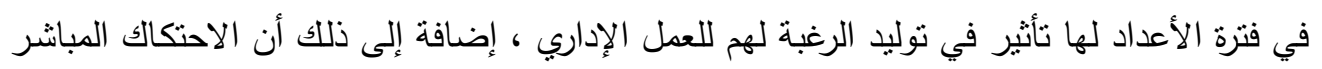

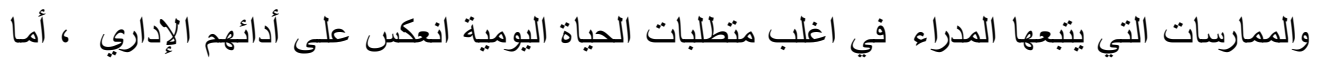

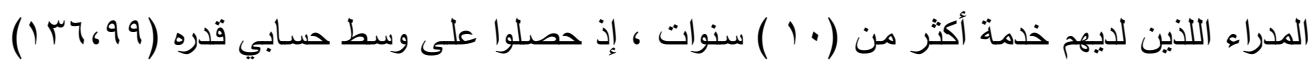




\section{العــــــد الثاني والعشرون}

\section{(}

\section{مجلـــة كليـــة التربيـــة}

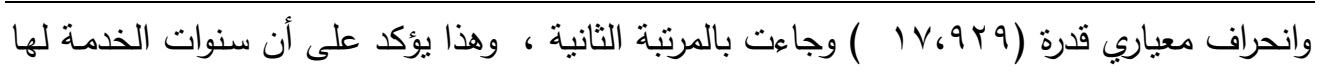

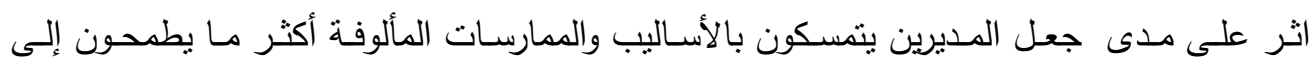

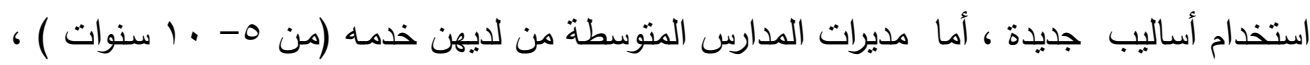

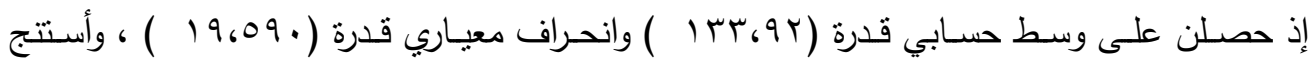

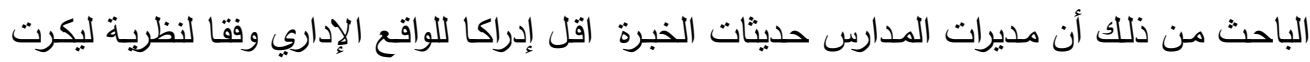

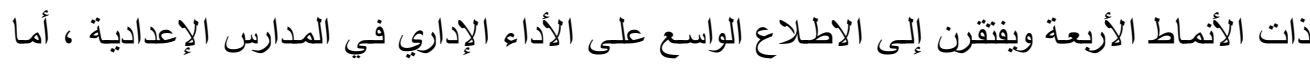

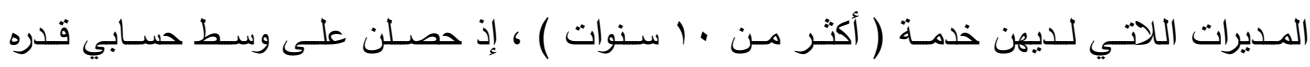

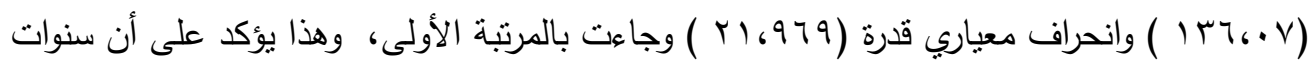

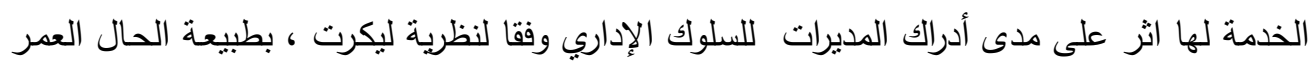

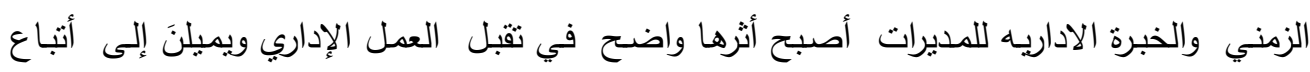

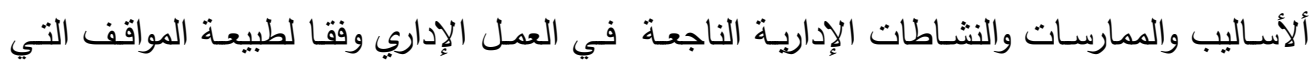

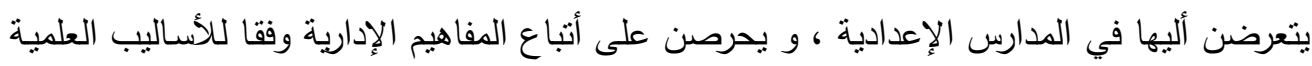
لأنهن يعدن أنفسهن تجاوزن المرحلة بحكم سنوات الخدمة الكبيرة لديهن.

ولمعرفه الفروق ذات الدلالة الإحصائية في السلوك الإداري وفقا لنظرية ليكرت لاى مديري المدارس

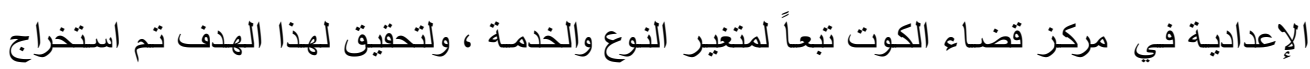

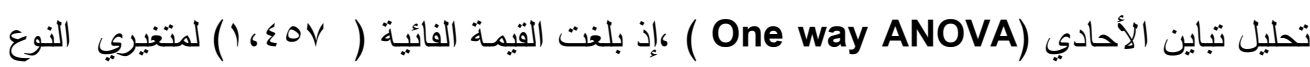

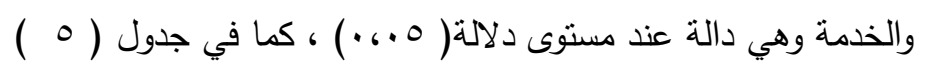




\section{العـــــــد الثاني والعشرون}

\section{جدول(0)}

يبين نتائج تحليل التباين الأحادي (One way ANOVA) للفرق بين متوسطات استجابات أفراد مجتمع البحث حول درجة السلوك الإداري نظام (1- ع ع ) لدى مديري الددارس الإعدادية في مركز قضاء الكوت وفقا للنوع وسنوات الخدمة لـ درجه

\begin{tabular}{|c|c|c|c|c|c|}
\hline 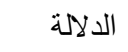 & f & df & متوسط المربعات & مجموع المربعات & مصدر التباين \\
\hline .6111 & r. $\{\leqslant 7$ & 1 & 9506.91 & 9406.91 & النوع ل \\
\hline $.6 \mathrm{VIV}$ & . . & 1 & $\leqslant 9,100$ & $\leqslant 9,100$ & الخدمة \\
\hline . GY9 & $1, \varepsilon 0 V$ & 1 & 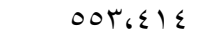 & $004 ، \varepsilon 1 \varepsilon$ & النوع والخدمة \\
\hline & & $r \leq r$ & rva.911 & QTr।A.T. & الخطأ \\
\hline & & $r \leq 7$ & & $\varepsilon V Y 109 \Lambda_{6} \ldots$ & المجموع \\
\hline
\end{tabular}

تبين كما في الجدول ( م ) بـان قيمـة الفائية المحسوبة لكل من متغير النوع و مدة الخدمـة

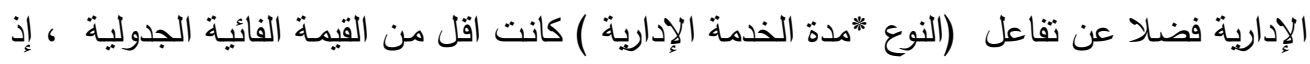

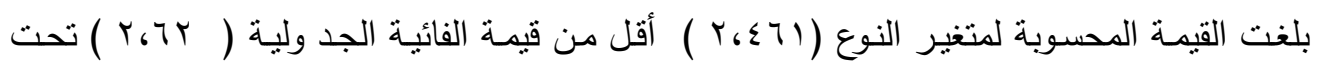

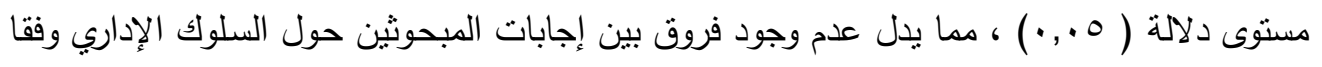

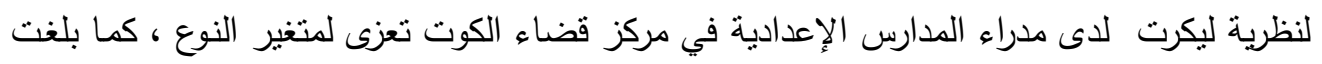

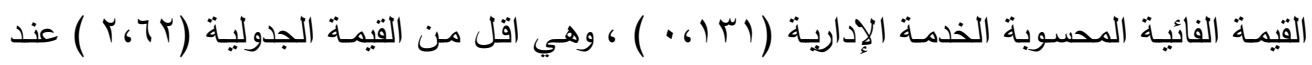

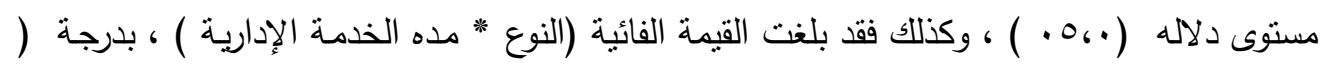

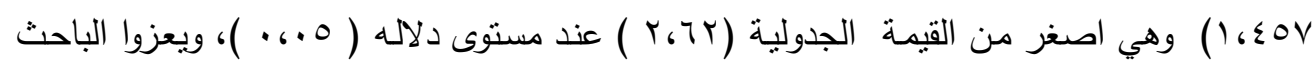




\section{العــــــد الثاني والعشرون}

\section{مجلـــة كليـــة التربيـــة}

ذللك جميع الددراء الددارس(الذكور والإناث ) ينبعون نفس الأساليب الإدارية وقد يكون البعض منها

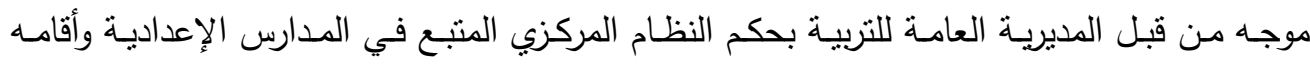

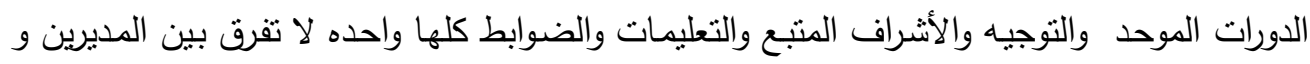

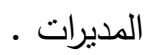

\section{الهذف الثاني:}

\section{الكثف على درجة الروح المعنوية لمدراء المدارس الإعدادية في مركز قضاء الكوت}

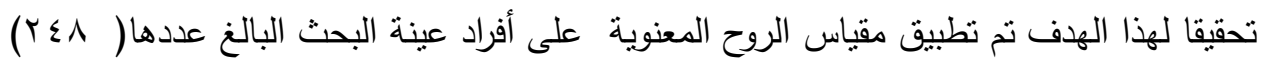

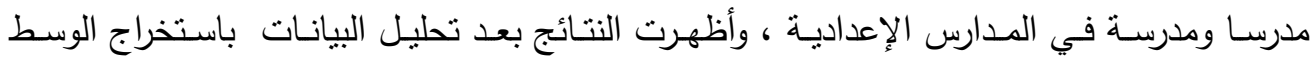

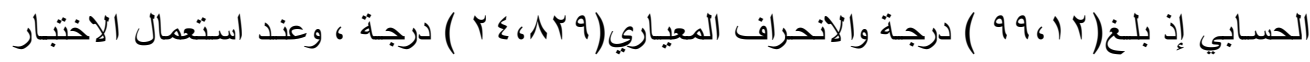

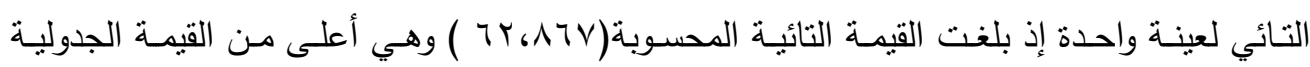

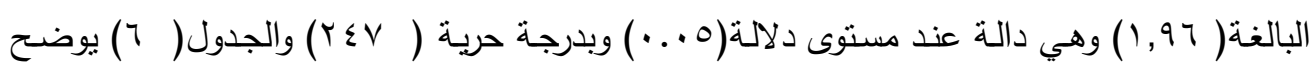

\section{جدول( )}

الاختبار التائي لعينة واحدة One Sample Statistics T- test لمقياس الروح المعنوية

\begin{tabular}{|c|c|c|c|c|c|c|c|}
\hline \multirow{2}{*}{ مستوى الدلالة } & \multicolumn{2}{|c|}{ القيمة التائية } & \multirow{2}{*}{ الفرضط } & \multirow{2}{*}{ الانحراف } & \multirow{2}{*}{ الحسابي } & \multirow{2}{*}{ عديد } & \multirow{2}{*}{ المتغير } \\
\hline & الجدولية & المحسوبة & & & & & \\
\hline دالة & 1,97 & イイ،ヘTV & 17. & $r \varepsilon$ \& $\wedge r q$ & 99617 & $r \leqslant \wedge$ & المعنوية \\
\hline
\end{tabular}

هذه النتيجة تثتير إلى أن مدرسي الدارس الإعدادية يتمتعون بروح معنوية عالية ، اذ تبين من

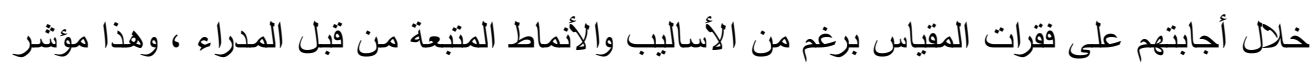




\section{العــــــد الثاني والعشرون}

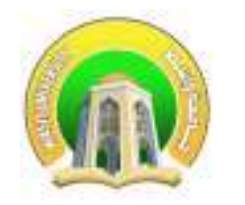

\section{مجلـــة كليـــة التربيـــة}

يدل على أن لاى المدرسين نضج ووعي في تحمل المسؤولية والتمتع بمبدأ ذاتية العمل التربوي و الإيمان الحقيقي في مهنة التنريس في المدارس الإعدادية.

الهـف الثاني : التعرف على الفروق بين استجابات أعضساء الهيئة التدريسية لمقياس الروح المعنوية حب النوع ( ذكر- أنثى ) و سنوات الخدمة ( من ه- ـ 1 سنوات ، وأكثر من • 1 سنوات )

\section{جدول( )}

يبين الأوساط الحسابية والانحرافات المعيارية لمقياس الروح المعنوية حسب النوع والخدمة

\begin{tabular}{|c|c|c|c|c|}
\hline العينة & الانحراف المعياري & الوسط الحسابي & الخدمة & النوع \\
\hline vo & ro,.r. & 99.07 & من ه- . 1 سنوات & \\
\hline$\varepsilon \Lambda$ & ro,rol & 1...1T & أكثر من · · سنوات & \\
\hline IrT & Yo, $.1 \leqslant$ & $99 . \vee \wedge$ & & المجموع \\
\hline VV & ro, $\leqslant \leqslant 9$ & $1 \cdots .90$ & من 0- . 1 سنوات & \\
\hline$\leqslant \wedge$ & TMGTMI & $9\{، \varepsilon \wedge$ & أكثر من · ا سنوات & \\
\hline ro & YE⿱VYA & $9 \Lambda_{6} \leq 4$ & & 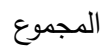 \\
\hline
\end{tabular}

وسيتم مناقثنة نتائج مقياس الروح المعنوية وعلى النحو الآتي :

أظهرت نتائج البحث أن أنثار الروح المعنوية أصبحت واضحة لدى مدرسي المدارس الإعدادية

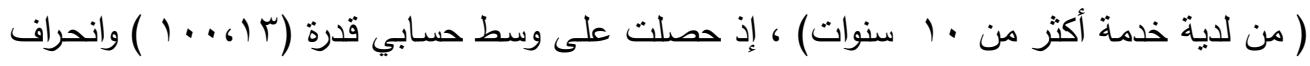

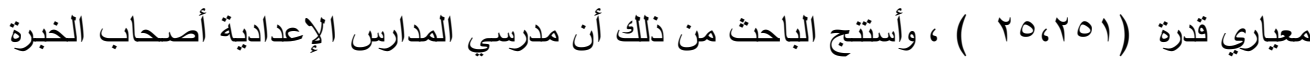

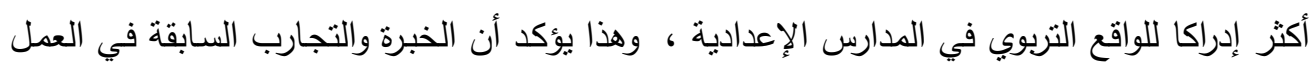


التربوي أخذت حيز واضح للعيان من خلال التعاون والانسجام فيما ينهم وبين الإدارة المدرسية ، أما المدراء اللذين لديهم ( خدمة من 0- • 1 ) سنوات ، إذ حصلوا على وسط حسابي قدره (99،07 )

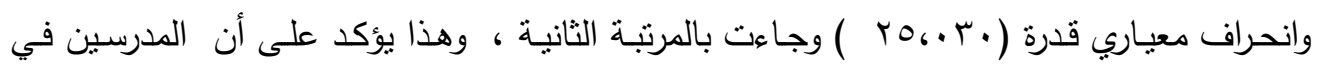
المدارس الإعداديـة من أصحاب الخبرات القليلة أكثر انخفاض للروح المعنويـة مقارنـه مـع اقرأنهم المدرسين اللذين لديهم الخبرات الطويلة في العمل التربوي ، وهذا يدل على عدم الانسجام وأتباع الطرق والأساليب الملائمة ، أضافه إلى ذلك قلة مبدأ العلاقات الإنسانية في الإدارة المتمثلة بالحكمة والصبر والتاني في إصدار القرارات كل هذا لـه اثأر مباشـرة على نفوس المدرسين ورفع روحهم

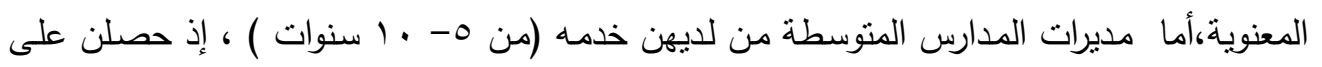

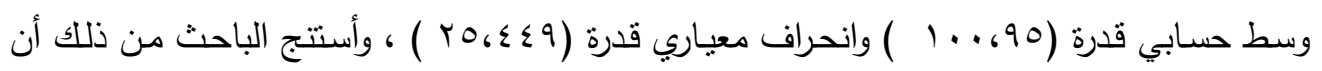
مديرات المدارس أكثر حرصسا على رفع الروح المعنويـة للمدرسـات ، ولديهن الطموح إلى التغيير

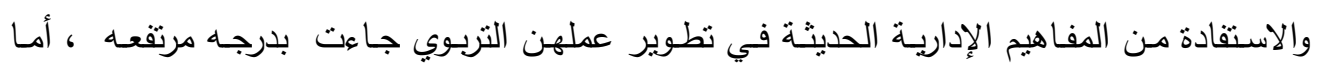

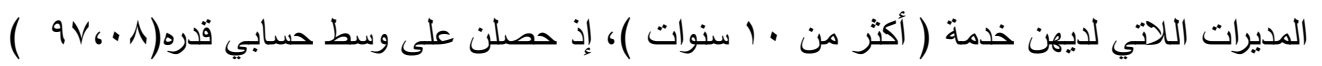

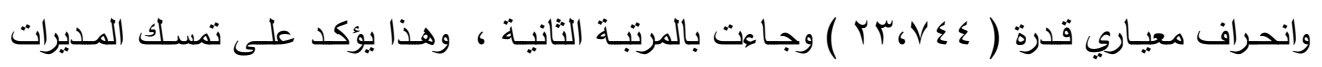
بأساليب التقليد والتمسك بالسلطة برغم من أنها تلحق التذمر والملل على المدرسات لأنها تعتمد

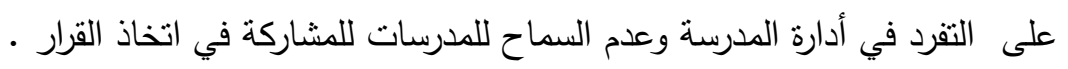
ولمعرفه الفروق ذات الدلالـة الإحصـائية في الروح المعنويـة لداء مديري المدارس الإعداديـة في مركز قضـاء الكوت تبعـاً لمنغير النوع والخدمـة ، ولتحقيق لهذا الهدف تم استخراج تحليل تبـاين

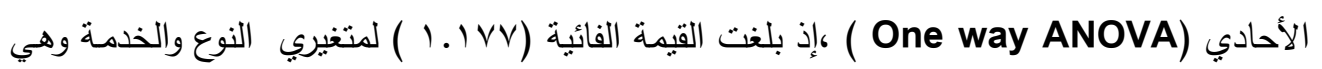

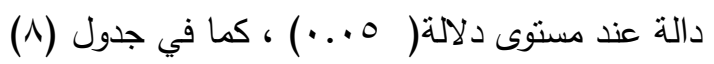




\section{العـــــــد الثاني والعشرون}

\section{مجلــــة كليــــة التربيـــة}

\section{(^) جدول}

يبين نتائج تحليل التباين الأحادي( One way ANOVA) للفرق بين متوسطات استجابات أفراد

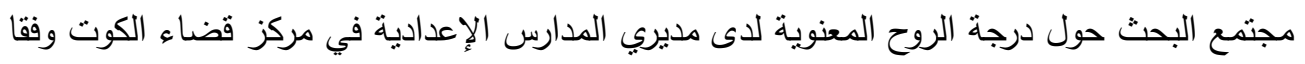

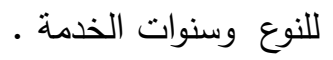

\begin{tabular}{|c|c|c|c|c|c|}
\hline الدلالة & $f$ & $d f$ & متوسط المريعات & مجموع المربعات & مصدر التباين \\
\hline .014 & 1 & 1 & หาร.7 & พา4.7 & النوع النوع \\
\hline ז4r. & . Arq & 1 & 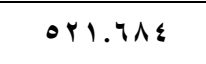 & 01 OI.TA & الخدمة \\
\hline \multirow[t]{3}{*}{.rVq } & $1.1 \mathrm{VV}$ & 1 & VYY.VY. & VYY.VY. & النوع والخدمة \\
\hline & & $r \leq \varepsilon$ & $71 \wedge . \leqslant 9$. & 10.911 .0 .1 & الخطأ \\
\hline & & $r \leqslant \wedge$ & & ro11409.... & المجموع \\
\hline
\end{tabular}

كما في الجدول ( ) بان قيمة الفائية المحسوبة لكل من متغير النوع و مدة الخدمة الإدارية

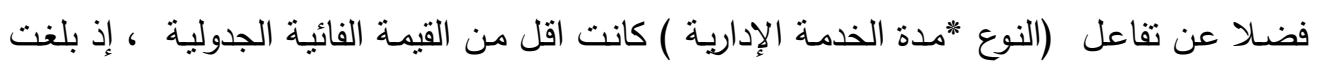

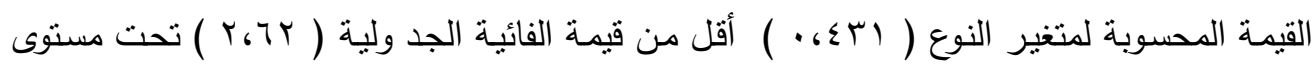

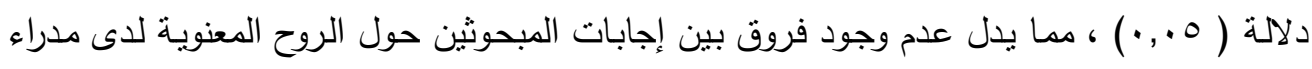

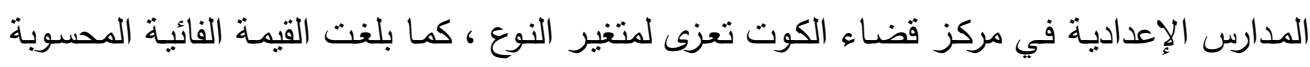

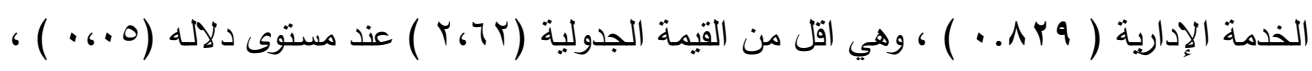

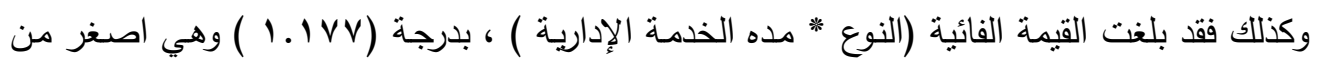

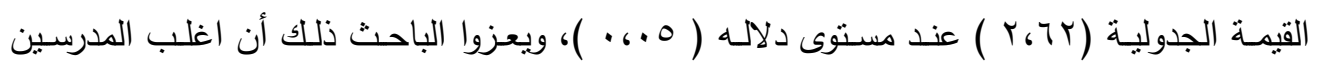




\section{العـــــــد الثاني والعشرون}

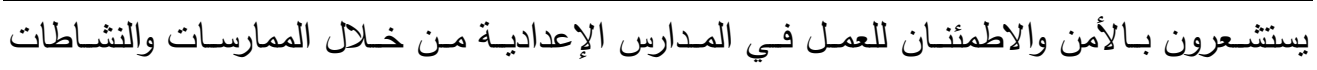

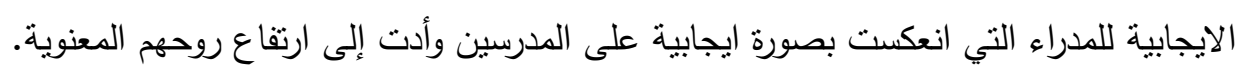

الهـف الثالث : هل توجد علاقـة ارتباطيـة بـين السلوك الإداري والـروح المعنويـة لـى مـدراء

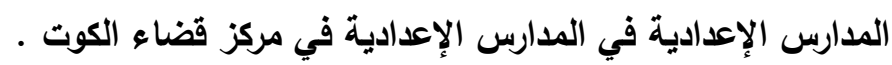

جدول (9)

يوضح نتائج معامل ارتباط بيرسون لتحديد العلاقة بين السلوك الإداري والروح المعنوية لدى مدريري المدارس الإعدادية في قضاء الكوت.

\begin{tabular}{|c|c|c|}
\hline الدلالة الإحصائية & معامل الارتباط & المتغير \\
\hline \multirow[t]{2}{*}{$\cdot, \cdot 0$} & \multirow[t]{2}{*}{.671} & السلوك الإداري \\
\hline & & الروح المعنوية \\
\hline
\end{tabular}

القيمة الحرجة لمعامل ارتباط بيرسون =9 ., • بدرجة حرية Y Y عند مستوى دلالة ( . ., )

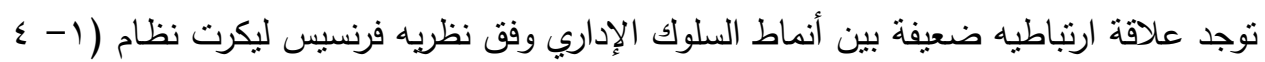

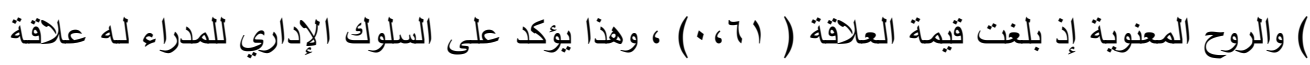

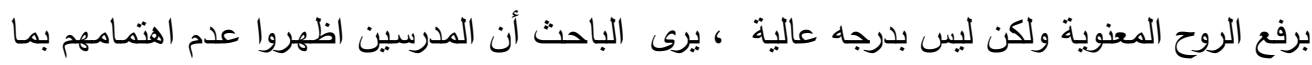

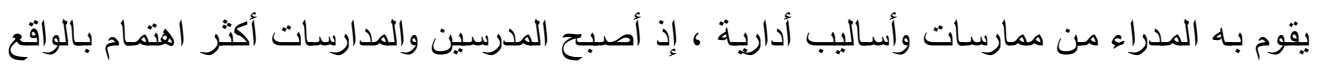

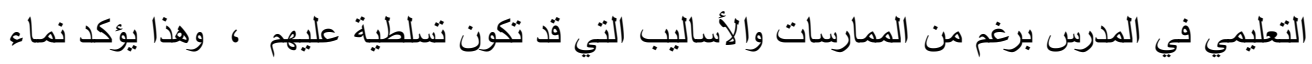

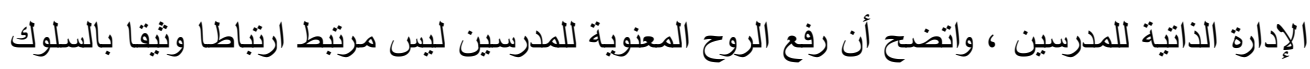

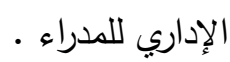


الاستنتاجات :

من خلال العرض السابق للإطار النظري وأدبيات الدراسة ولنتائج التحليل الإحصائي لدجالات

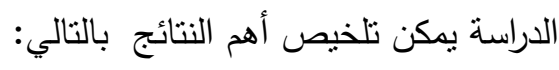

1- إن المدراء يتبعون السلوك أداري وفقا لنظرية ليكرت نظام (1-؛ ) بدرجه عاليه .

r- حصل متغير النوع (الذكور والإناث ) على درجه عاليه من السلوك الإداري ، وأصبح لهم تأثير

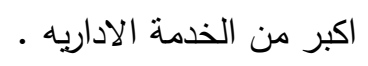

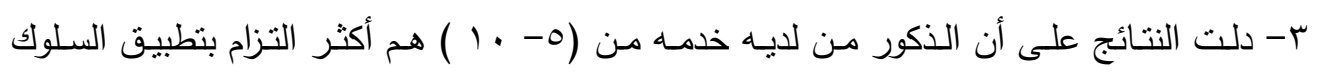

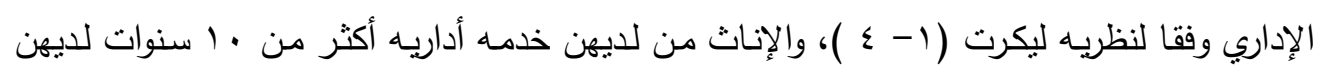
سلوكا أداريا عال وفقا للنظرية

ع - أظهرت النتائج على أن هناك ارتفاع في الروح المعنوية للمدرسين في المدارس الإعدادية في مركز قضاء الكوت .

ه - وجود علاقة ارتباطيه ضعيفة بين السلوك الإداري والروح المعنوية للددرسين. التوصيات :

في ضوء ما توصل أليه البحث الميداني واستكمالا لبحث جوانب أو متغيرات أخرى للبحث يقترح الباحث الآتي : 1- تعزيز السلوك الإداري وفقا لنظرية ليكرت نظام (1- ع ) في المدار الإعدادية . r- التأكيد على أتباع السلوك الإداري لنظرية ليكرت نظام (1-؛ ) لمديرات المدارس الإعدادية . r- دعم العلاقة بين السلوك الإداري وفقا لنظرية ليكرت نظام ( ا-؛ ) والروح المعنوية لأنها ليست

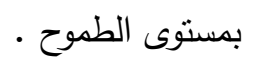


العـــــــد الثاني والعشرون

\section{مجلـــة كليــــة التربيــــة}

ع - الحفاظ على مبدأ الروح المعنوية للمدرسين والمدرسات في المدارس الإعدادية لما له دور كير

في تحقيق الإنتاجية العلمية.

: المقترحات

$$
\text { يقترح الباحث ما يلي : }
$$

1- إجراء مزيد من الدراسات لتطبيق السلوك الإداري لنظرية ليكرت نظام ( - ـ ) مع متغيرات أخرى في المدارس المتوسطة .

ץ-إجراء مزيد من الدراسات المقارنة بين السلوك الإداري وفقا لنظرية ليكرت والثبكة الإدارية لبليك مونن.

r- إجراء دراسات لمعرفة الروح المعنوية للمدراء من وجهة نظر مشرفيهم.

ع -إجراء دراسات لمعرفه الروح المعنوية وعلاقتها بالجودة التعليمية . 
المصادر

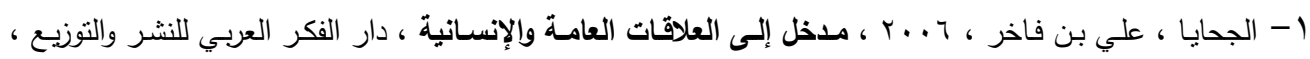

مصر

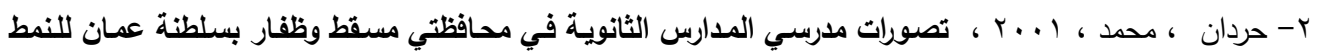

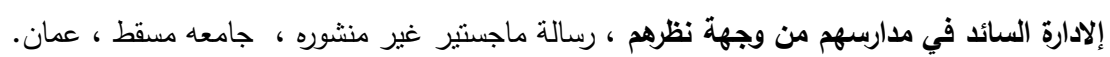

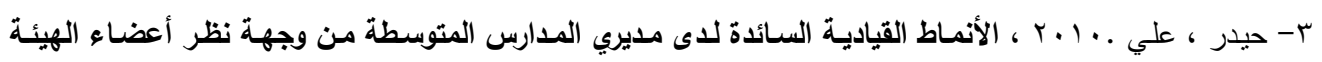

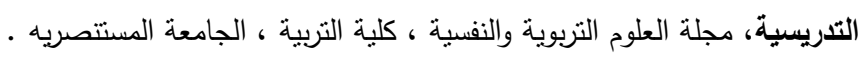

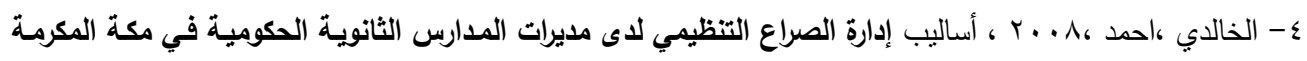
وعلاقتها بالروح المعنوية للمعلمين ، رسالة ماجستير غير منشوره ، جامعه أم القرى ، السعودية.

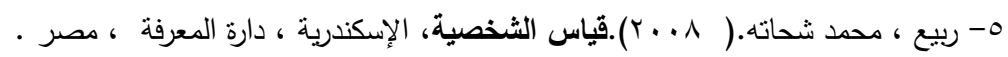

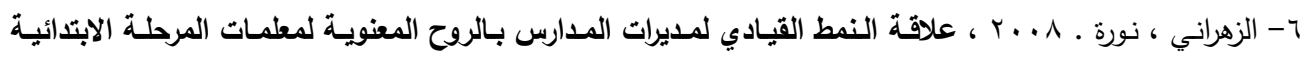

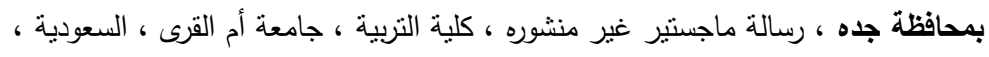

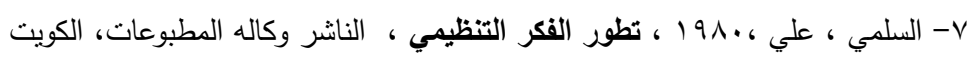

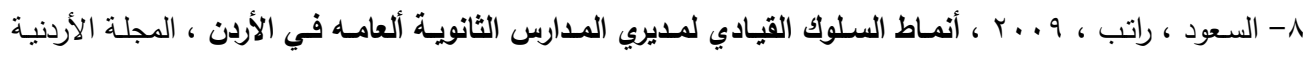

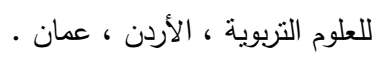

9- الثيباني، عمر وحمد ،1910 ، الفكر التربوي بين النظرية والتطبيق ، المنشاة العامة للنشر والتوزيع ، طرابلس،

ليبيا.

• 1- عودة، أحمد سليمان ، ب991 أساسيات البحث العلمي في التربية والعلوم الإنسانية - طץ- مكتبة الكتاني الأردن.

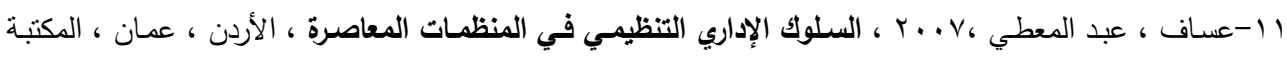

الوطنية

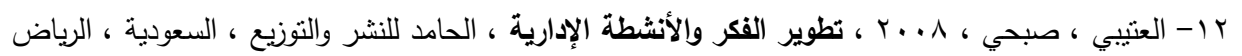

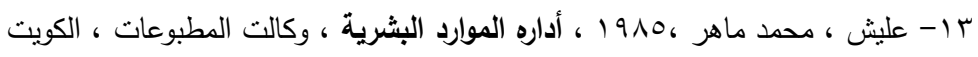

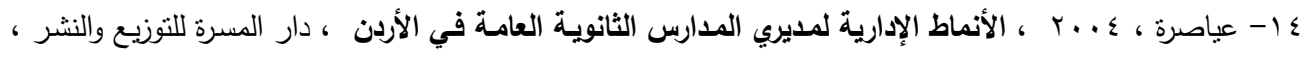

الأردن ، عمان - العبان

10 - العتيبي ، سعود محمد و السواط ، طلق ، عوض اله ، . . . . ، الولاء التنظيمي لمنتسبين جامعة الملك عبد

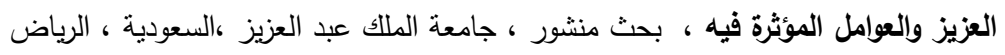

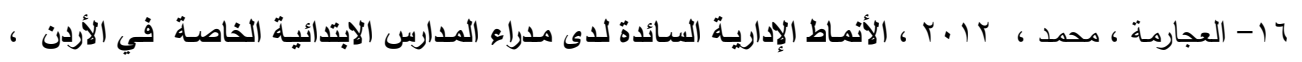

رسالة ماجستير غير منشوره ، الأردن ، عمان ، أب ، الانماطل 


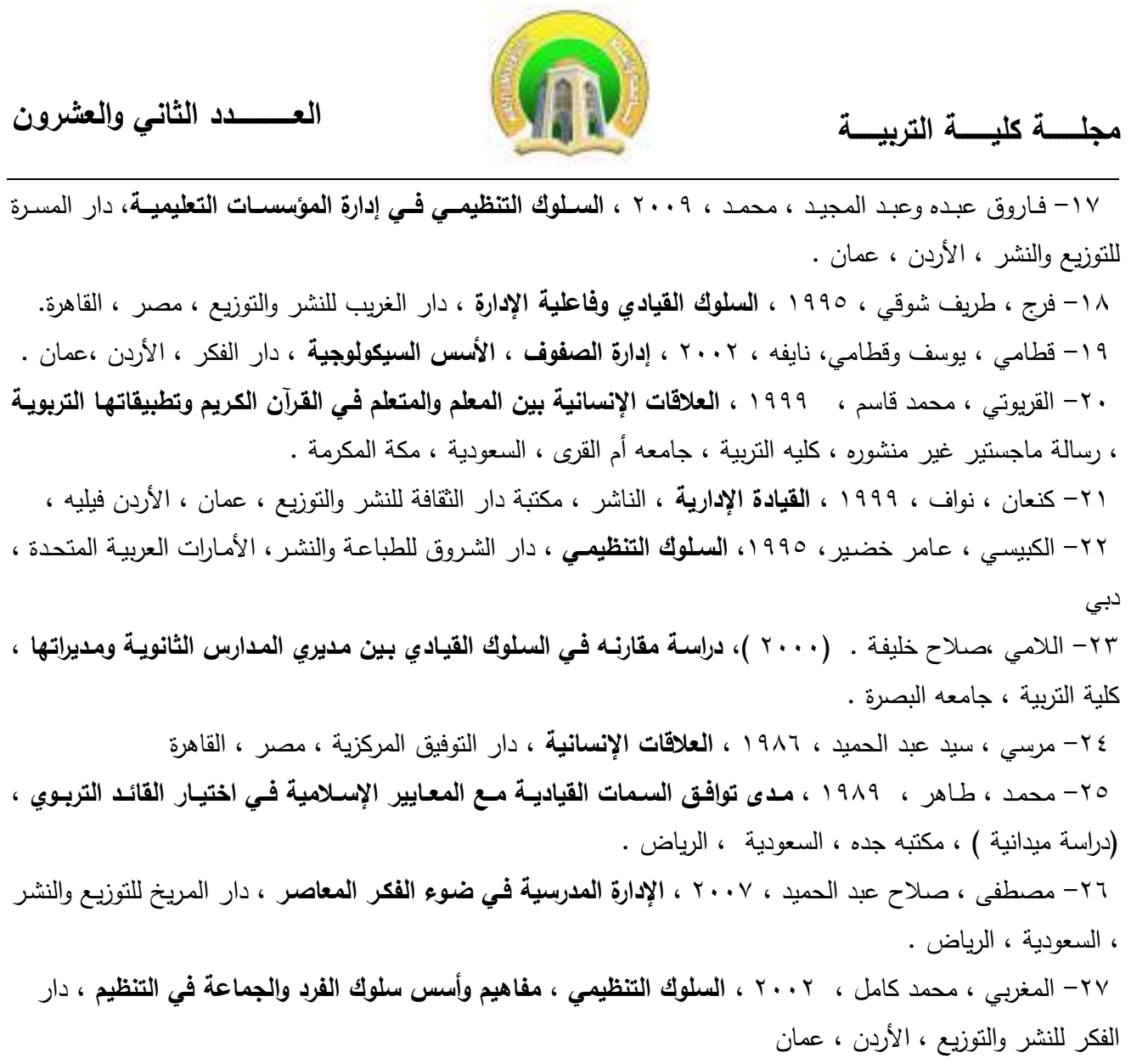

28- Costello. C.C. (1996) personality Characteristics of the personality disordered john. Wilex sons new York.

29 - Duval.S. and wichlund R.A(1976) Effects of objective self awareness on attribution of causality Journal of Experiment Social Psychology.

30- Dawaln,1987, The relationship between perception director.

31- Ebel, R Administration style and grasp Amwalimaan to this pattern in northern Ohio 1972, , "Essenntials of Educational Measurement " New York. Englewood and Cliffs, J.F. prentice- Hall.

32- Frederick Hers berg, 1959 , work participation in Management in the fedoras Republic of Germany ed Labor studier.

33- Klawitter, Pamela 1986 : The Relationship Between Principals , Leadership style and Teacher Job action . D.A.L.

34- Harent .D 1982 , Statisti ,Statistical methods .3 . $^{\text {rd }}$ ad ,Lnt Philippines copyright:

Addison .Wesley publishing company, London.

35 -Likert ,R19961, New pattern of Management ,New York Mc Graw - Hill book company.

36- Morten,A.Phillip.(1984).Personality Theories,Torento:McGraw Hi.

37- Marsh ,Robert ,and Manner, Hirosh, 1972, Organizational Commitment and turnter Aprediclion study Administratrative science Quartery.

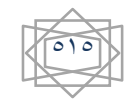


38- Massaro \& Augustus ,2000, Teacher percent of school climate self and . princiported leaderships tylebased 


\section{العـــــــد الثاني والعشرون}

\section{مجلـــة كليـــة التربيـــة}

ملحق (1)

جامعة واسط

كلية التربية

قسم العلوم التزبوية والنفسية

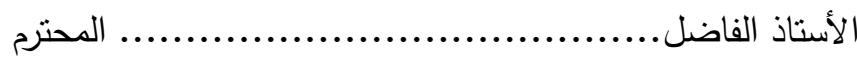

\section{استبانة بصورتها الأولية}

يروم الباحث أجراء دراسته الموسومة ب(أنماط السلوك الإداري لمديري المدارس الإعدادية وفقاً لنظرية رنسيس ليكرت

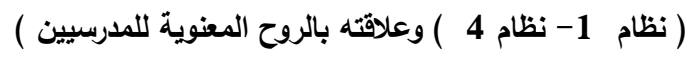

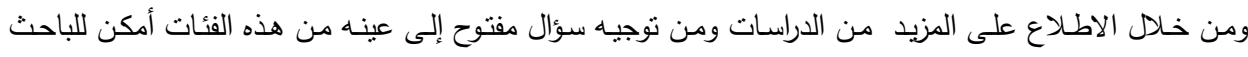
التوصل إلى العديد من الفقرات التي تعبر عن أهداف البحث ، ولتحقيق هدف الدراسة يعرض علئ عليكم الباحث استبانه من

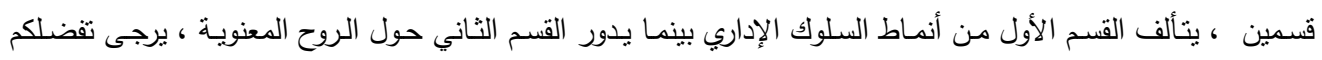

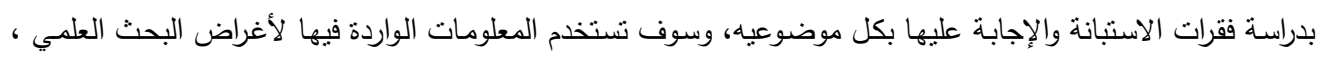

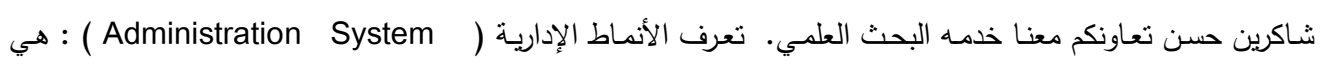

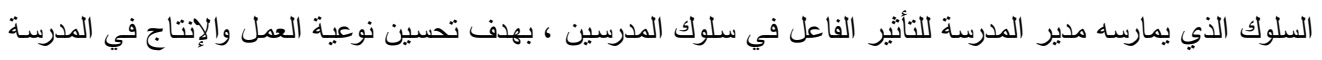

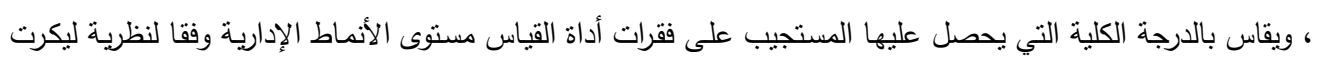

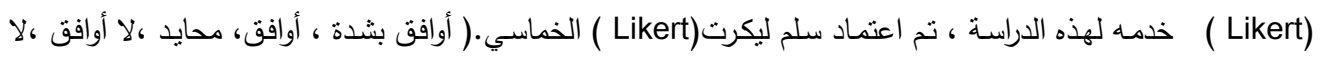

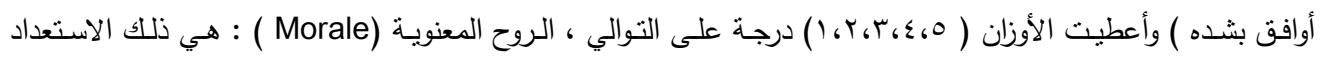

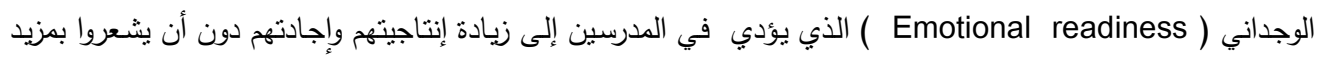

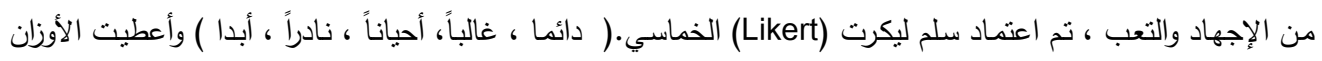

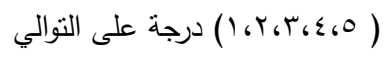

$$
\text { الباحث }
$$

م.د. (1) - nبد كاطع سموم 
1- النمط الاسنشـاري الديمقراطي( System Democratic Consultative ): هو أعطساء الددرسين فرصة لإبداء الرأي وتقديم الاقتراحات فيما يتخذ من قرارات أو تحيد أهداف أو وضع معايير

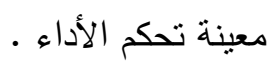

\begin{tabular}{|c|c|c|c|c|}
\hline التعديل & غير & صالحه & الفقرات & ت \\
\hline & & & يوازن المدير في قراراته بين ظروف العمل والمدرسين . & 1 \\
\hline & & & يوفر المدير التغذية الراجحة للمدرسين. & r \\
\hline & & & يطلع المدير المدرسين على المستجدات التزبوية . & $r$ \\
\hline & & & يهنم المدير بإثباع الحاجات الاجتماعية للمدرسين. & $\varepsilon$ \\
\hline & & & يشجع المدير قنوات الاتصال بينه وبين المدرسين. & $\circ$ \\
\hline & & & يهتم المدير بمشكلات المدرسين . & 1 \\
\hline & & & يستمع المدير لأراء المدرسين جميعا قبل اتخاذ القرار. & v \\
\hline & & & يفوض المدير كثيرا من صلاحيات للمدرسين . & $\wedge$ \\
\hline & & & براعي المدير اهتمامات المدرسين · & 9 \\
\hline & & & يأخذ المدير ملاحظات المدرسين بعين الاعتبار . & 1. \\
\hline
\end{tabular}

r- النمط ألتشـاركي الديمقراطي( System Participative Democratic ) هو خلق المناخ الصالح والملائم التشجيع التغيير وتقبله في أطار مصلحة المدرسين والمدرسة.

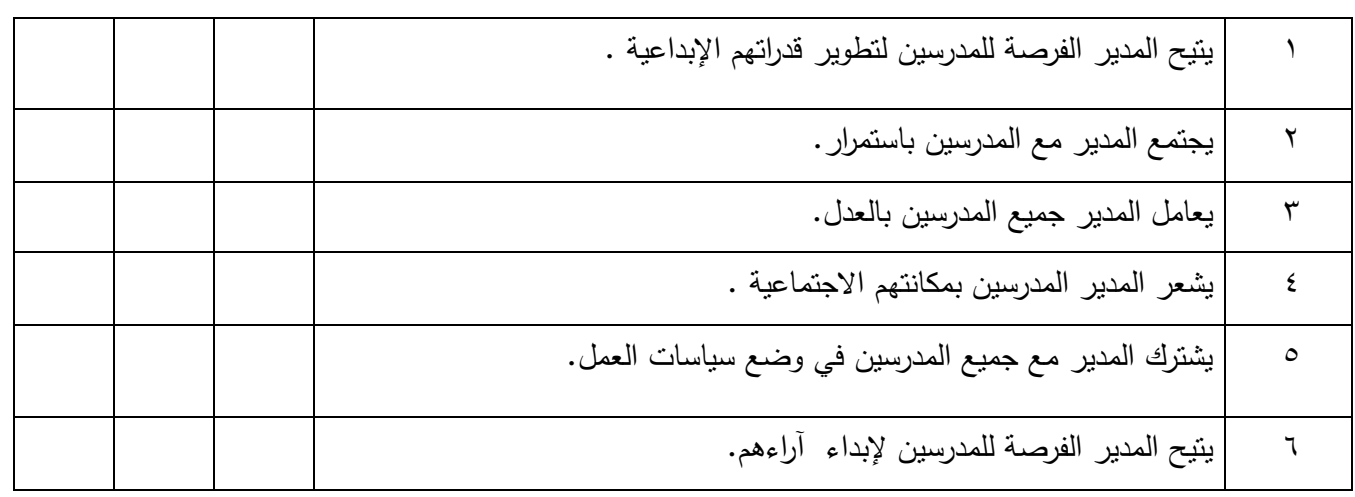




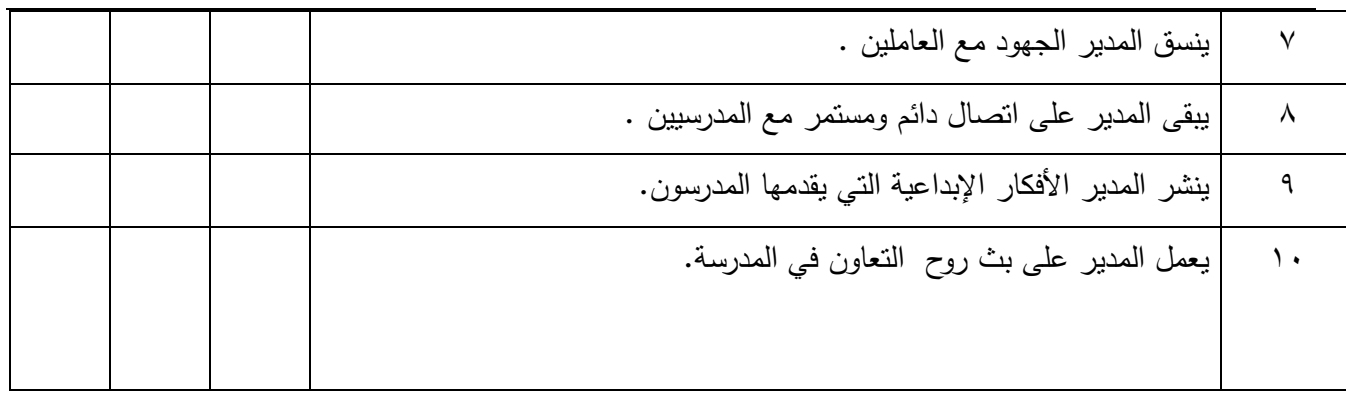

r- النمط الاستبدادي الخير :System Benevolent Authoritative :هو المدير الذي يثق في نفسه وفي طريقة أداءه للعمل ، ويتركز اهتمامه على تحقيق مستوى أداء مرتفع في الأجل القصير

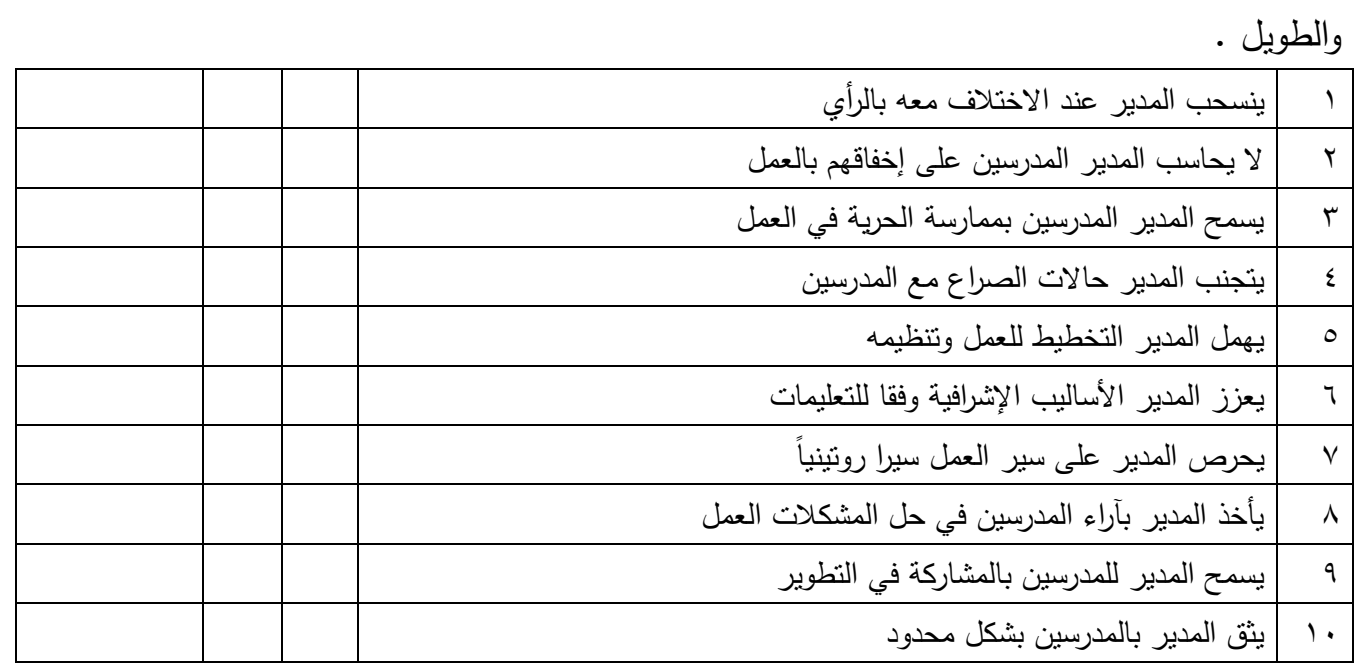

ع- النمط الاستبدادي التسلطي: System Exploitative Authoritative :هو المدير الذي يحاول

تركيز كل الصلاحيات بيده ويحتفظ بها لنفسه ولا يفوض الصلاحيات للأخريين .

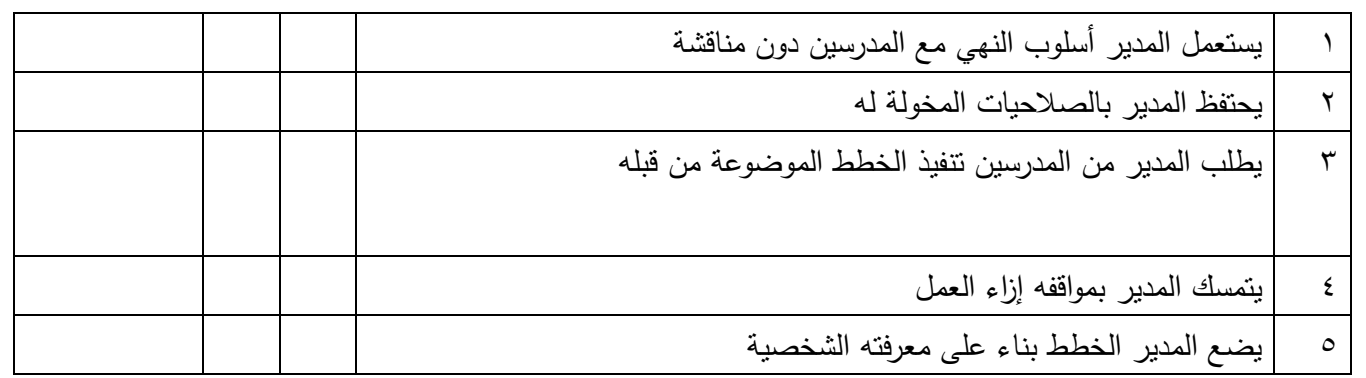




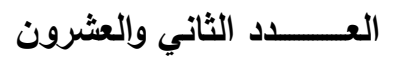

(A)

\section{المبحث الثاني: الروح المعنوية: ( Rorale )}

1- بعد العلاقات مع الزملاء (Relations with Colleagues) ) :(هي تلك العلاقات الطيبة التي تسود في الجماعة وتكوين الرغبة للجماعة أن تعيش وتعمل في انسجام والقضاء على الصراع التهاء

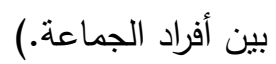

\begin{tabular}{|c|c|c|c|c|}
\hline مقترح & صالحير & صالحه & الفقرات & ت \\
\hline & & & يثارك زملائه في كافة المناسبات العامة والخاصة. & 1 \\
\hline & & & يحترم أراء زملائه في العمل بغض النظر عن كونها مطابقة لرأيه. & r \\
\hline & & & تؤثر التوجيهات الإدارية على طبيعة العلاقات الثخصية القائمة بينا. & r \\
\hline & & & يناقث مع زملائه الددرسين السلبيات والايجابيات المتعلقة بالعمل بروح معنوية. & $\varepsilon$ \\
\hline & & & يرى أن هناك تعاونا بين الزملاء في المدرسة. & $\circ$ \\
\hline & & & يدعم بموضوعية اقتراحات الزملاء الايجابية نحو التقدم والتطوير . & 7 \\
\hline & & & تتسم العلاقات بين المدرسين بالروح الأخوية . & $v$ \\
\hline & & & يحرص على تطوير أواصر الثقة والعلاقات الثخصية مع زملائه في العمل & $\wedge$ \\
\hline
\end{tabular}

r- بعد الحوافز والأجور والترقيات ( Incentives and Salaries ,Promotiones ) : ( بأنها العوامل أو الوسائل أو الأساليب تختارها الإدارات بعناية فائقة من اجل نوجيه السلوك الإنساني لكي

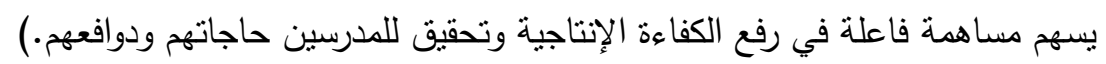

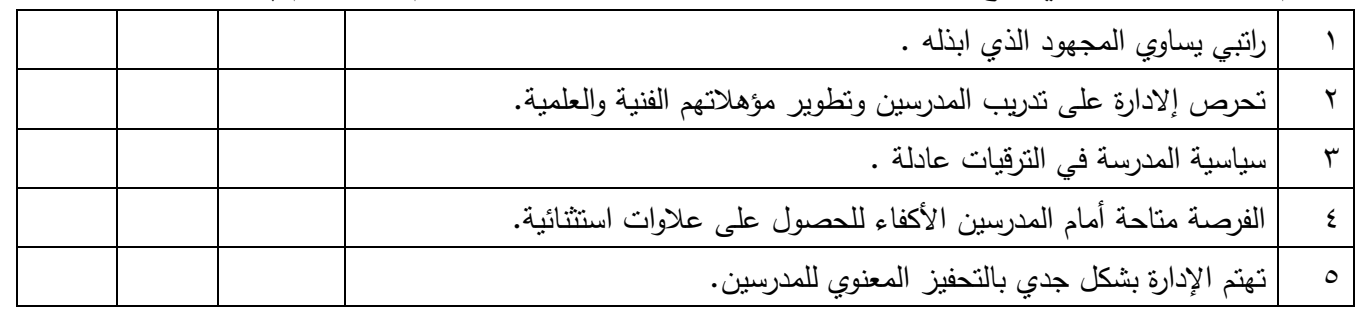



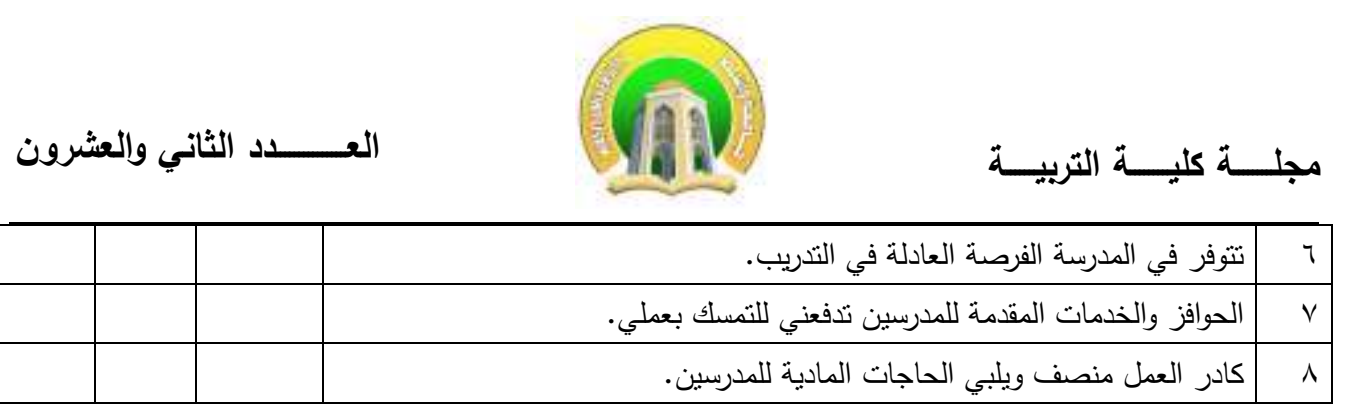

r- بعد ظروف العمل ( Working Conditions ) ) : (الثروط المادية التي يعمل فيها المدرسين

في المدرسة من ضوء وتهوية وإنارة ونظام فترات العمل والراحة.)

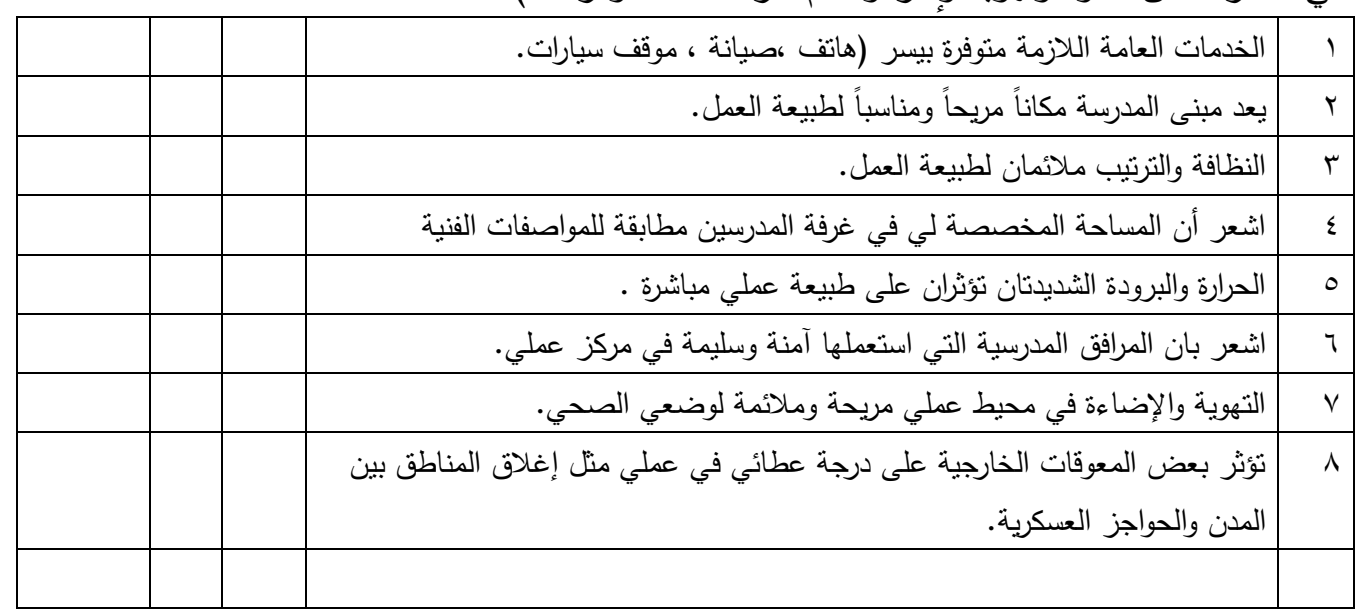

ع - بعد الأنظمة والتعليمات (The regulations and instractions ) : ( هي مجموعة القوانين واللوائح والتعليمات التي تتخذها الإدارة أساسا في الاختيار والمفاضلة حين اتخاذ القرارات . )

\begin{tabular}{|c|c|c|c|}
\hline & & الأنظمة هي المرجعية الوحيدة لنسير أمور المدرسة. & 1 \\
\hline & & تشمل أنظمة التوظيف في المدرسة الني اعمل بها ساعات عمل مناسبة وأجور عادلة. & r \\
\hline & & تحرص التعليمات إدارة المدرسة على مساعدة المدرسين في حل مشكلاتهم الإنسانية. & r \\
\hline & & نظام التوظيف في مدرستتا يراعي الأسس العلمية والإدارية ويتسم بالموضوعية. & $\varepsilon$ \\
\hline & & يعتمد التوظيف في مدرستتا على قاعدة الرجل المناسب في المكان المناسب. & 0 \\
\hline & & الطريقة المتبعة في اختيار المناصب الإدارية تتبع معايير مهنية . & 1 \\
\hline & & من السهل الاتصال بالرؤساء و المسؤولين . & $\checkmark$ \\
\hline & & التعليمات الصادرة عن مدير المدرسة واضحة وتأتي عادة بعد استشارة المدرسين. & $\wedge$ \\
\hline
\end{tabular}

ملحق ( r ) أسماء الخبراء وإلمحمين 


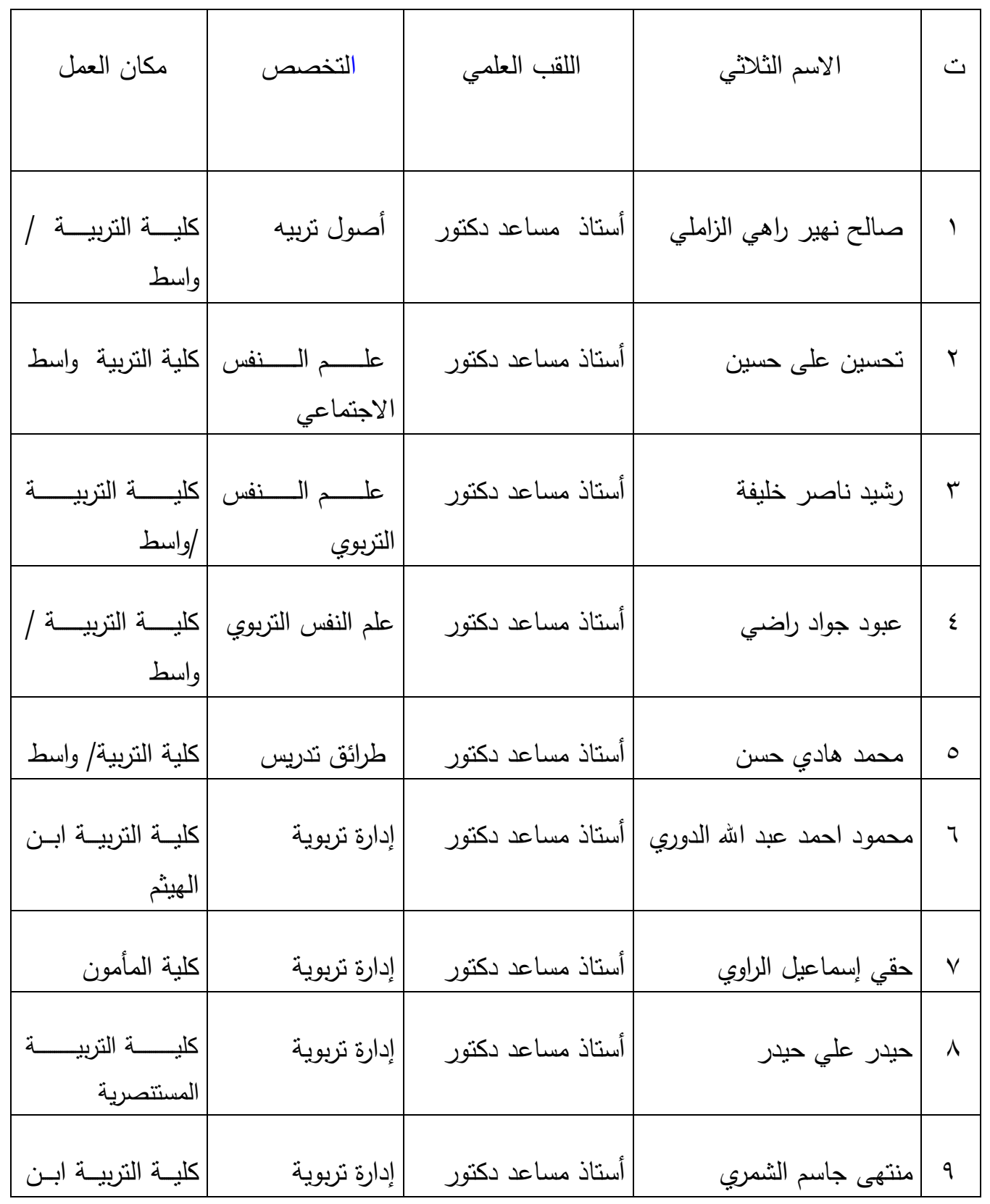


العــــــدد الثاني والعشرون

مجلـــة كليــــة التربيــــة

\begin{tabular}{|c|c|c|c|c|}
\hline رشد & & & & \\
\hline كلبــة التربيــة ابـن & قياس وتقويم & أستاذ مساعد دكتور & خالد جمال الدليمي & 1 . \\
\hline كليـة التربيـة ابـن & إدارة تربوية & أستاذ مساعد دكتور & علاء حاكم الناصر & 11 \\
\hline كليــة التربيـة ابـن & إدارة تربوية & أستاذ مساعد دكتور & بلسم احمد السامرائي & ir \\
\hline
\end{tabular}




\section{العـــــــد الثاني والعشرون}

\section{مجلـــة كليـــة التربيـــة}

ملحق (r) ( ) - (r)

جامعة واسط

كلية التربية

قسم العلوم التربوية والنفسية

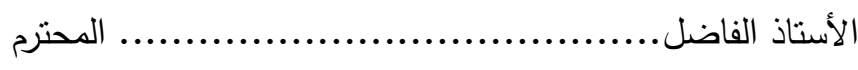

استبانة بصورتها النهائية

يروم الباحث أجراء دراسته الموسومة ب(أنماط السلوك الإداري لمديري المدارس الإعدادية وفقاً لنظرية رنسيس ليكرت

( نظام 1- نظام 4 ) ) وعلاقته بالروح المعنوية للمدرسيين )

ومن خلا الاطلاع على المزيد من الدراسات ومن توجيه سؤال مفتوح إلى عينه من هذه الفئات أمكن للباحث التوصل

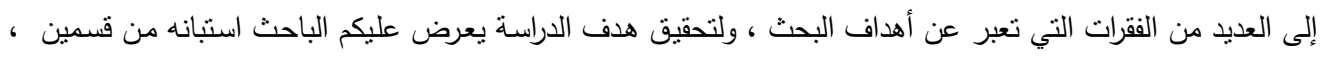

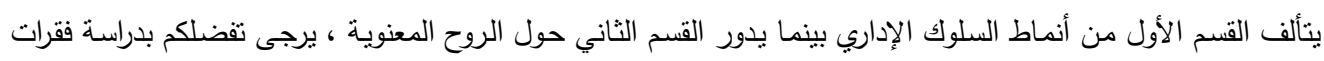

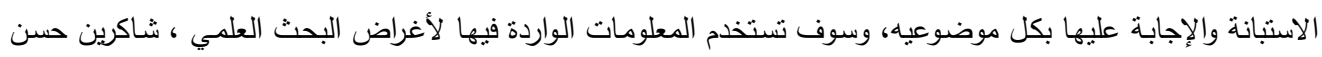

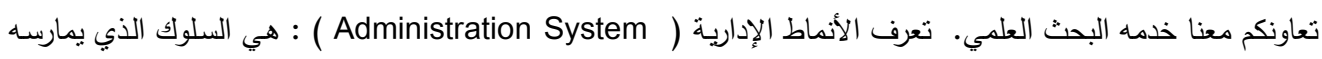

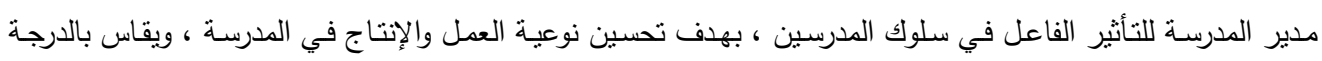

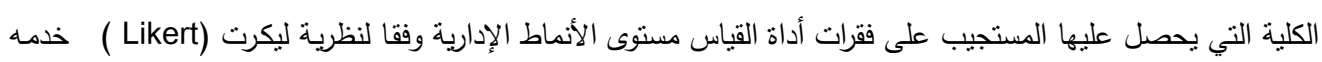

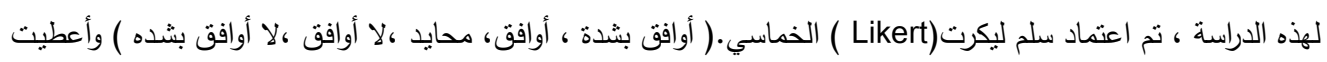

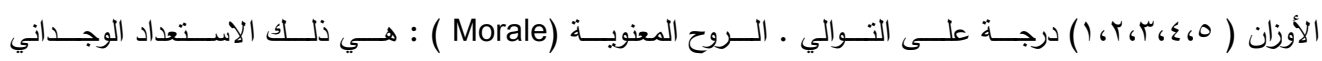
(الذي يؤدي في المدرسين إلى زيادة إنتاجيته وإجادتهم دون أن يشعروا بمزيد من الإجهاد ( Emotional readiness )

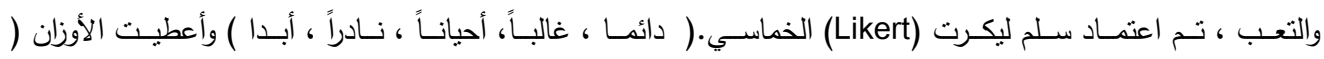

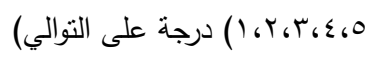

الباحث

م.د. عبد كاطع 
1- النمط الاستشاري الديمقراطي( System Democratic Consultative ) هو أعطاء

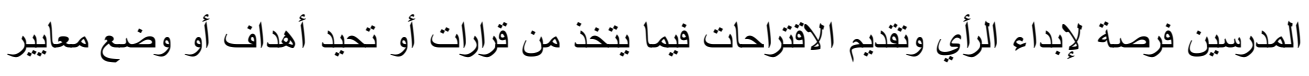
معينة تحكم الأداء.

\begin{tabular}{|c|c|c|c|c|c|c|}
\hline لا لأوافق & 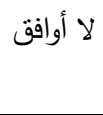 & محايد & أوافق & بشده & الفقرات & ت \\
\hline & & & & & يوازن المدير في قراراته بين ظروف العمل والمدرسين . & 1 \\
\hline & & & & & يوفر المدير التغذية الراجحة للمدرسين. & r \\
\hline & & & & & يطلع المدير المدرسين على المستجدات التربوية . & r \\
\hline & & & & & يهنم المدير بإثباع الحاجات الاجتماعية للمدرسين. & $\varepsilon$ \\
\hline & & & & & يشجع المدير قنوات الاتصال بينه وبين المدرسين. & 0 \\
\hline & & & & & يهتم المدير بمشكلات المدرسين • & 1 \\
\hline & & & & & يستمع المدير لأراء المدرسين جميعا قبل اتخاذ القرار. & $v$ \\
\hline & & & & & يفوض المدير كثيرا من صلاحيات للمدرسين . & $\wedge$ \\
\hline & & & & & براعي المدير اهتمامات المدرسين . & 9 \\
\hline & & & & & بأخذ المدير ملاحظات المدرسين بعين الاعتبار . & 1. \\
\hline
\end{tabular}

r- النمط ألنتاركي الديمقراطي( System Participative Democratic ) هو خلق المناخ الصالح والملائم لتتجيع التغيير وتقبله في أطار مصلحة الددرسين والمدرسة.

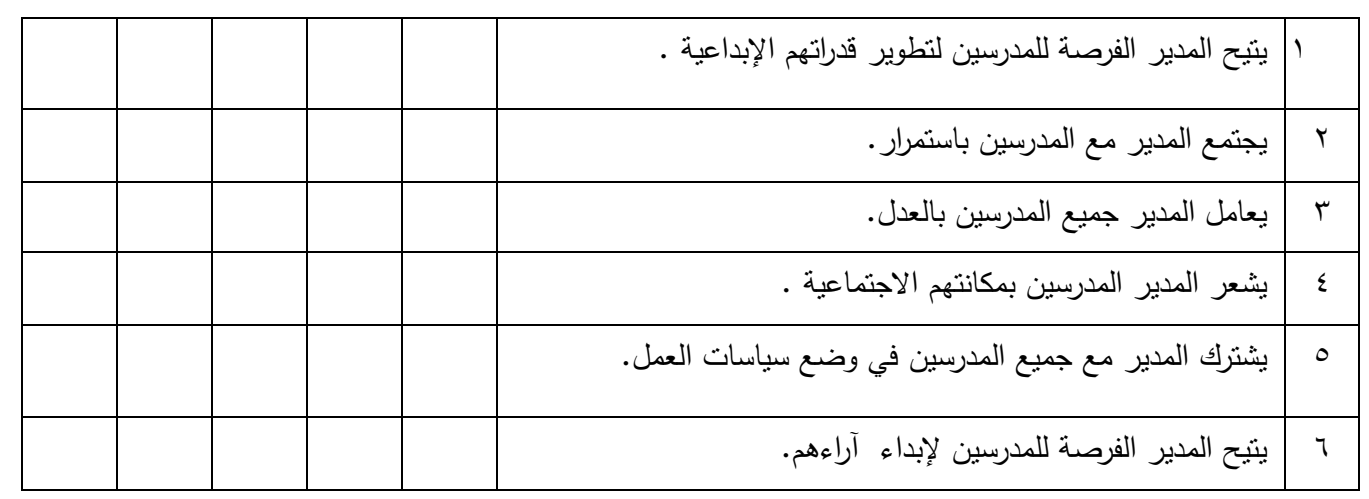




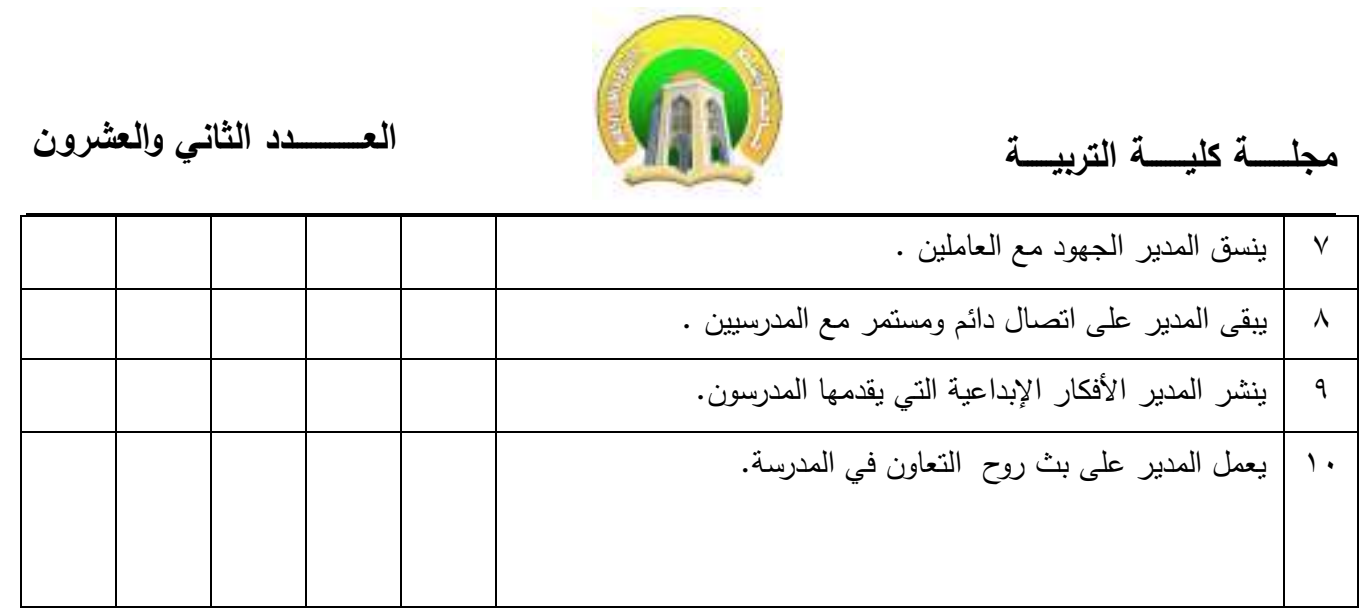

r- النمط الاستبدادي الخير:System Benevolent Authoritative :هو المدير الذي يثق في نفسه وفي طريقة أداءه للعمل ، ويتركز اهنمامسه على تحقيق مستوى أداء مرتفع في الأجل القصير والطويل

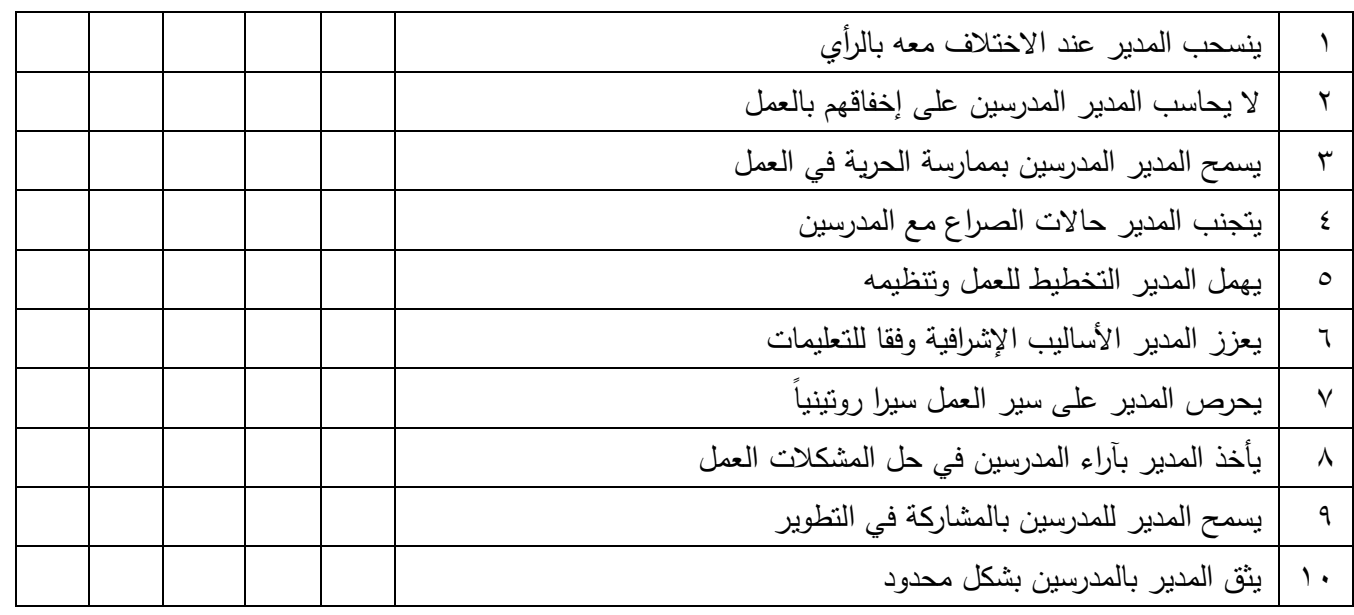

ع - النمط الاستبدادي التسلطي: System Exploitative Authoritative :هو المدير الذي يحاول تركيز كل الصلاحيات بيده ويحتفظ بها لنفسه ولا يفوض الصلاحيات للأخريين •

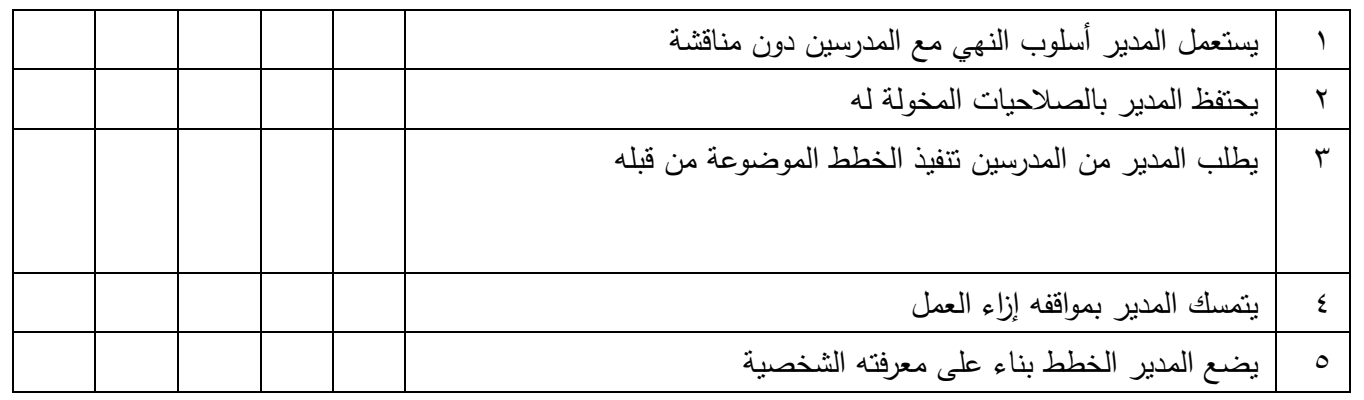


العـــــــد الثاني والعشرون

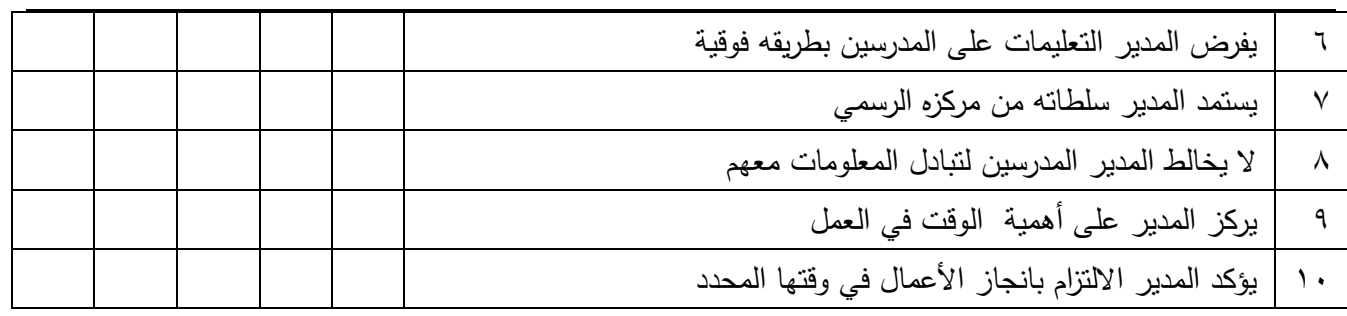

ثانيا: الروح المعنوية: ( Rorale )

1- بعد العلاقات مع الزملاء (Relations with Colleagues) ) :(هي تلك العلاقات الطيبة

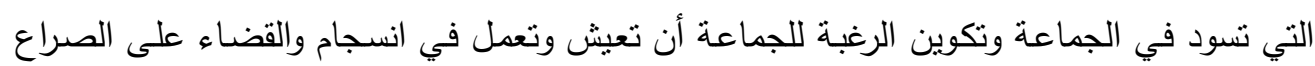

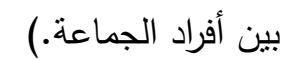

\begin{tabular}{|c|c|c|c|c|c|c|}
\hline أبدا & ناً & 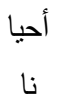 & غاً & دائماً & 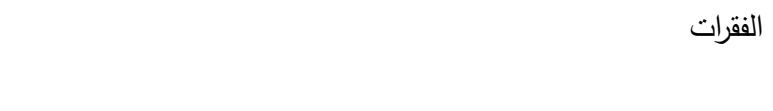 & $ت$ \\
\hline & & & & & يشارك زملائه في كافة المناسبات العامة والخاصة. & 1 \\
\hline & & & & & يحترم أراء زملائه في العمل بغض النظر عن كونها مطابقة لرأيه. & r \\
\hline & & & & & تؤثر التوجيهات الإدارية على طبيعة العلاقات الثخصية القائمة بينا. & r \\
\hline & & & & & منوفية. مع زملائه الدرسين السلبيات والايجابيات المتعلقة بالعمل بروح & $\varepsilon$ \\
\hline & & & & & يرى أن هناك تعاونا بين الزملاء في الددرسة. & 0 \\
\hline & & & & & يدعم بموضوعية اقتراحات الزملاء الايجابية نحو النقدم والتطوير . & 1 \\
\hline & & & & & تتسم العلاقات بين المدرسين بالروح الأخوية . & v \\
\hline & & & & & العمل عحص على تطوير أواصر الثقة والعلاقات الثخصية مع زملائه في & $\wedge$ \\
\hline
\end{tabular}

r- بعد الحوافز والأجور والترقيات ( Incentives and Salaries,Promotions ) : ( بأنها العوامل أو الوسائل أو الأساليب تختارها الإدارات بعناية فائقة من اجل نوجيه السلوك الإنسات الإنساني لكي

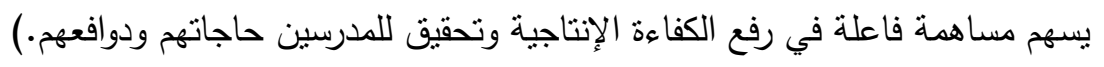




\section{العـــــــد الثاني والعشرون}

\section{مجلـــة كليــــة التربيـــة}

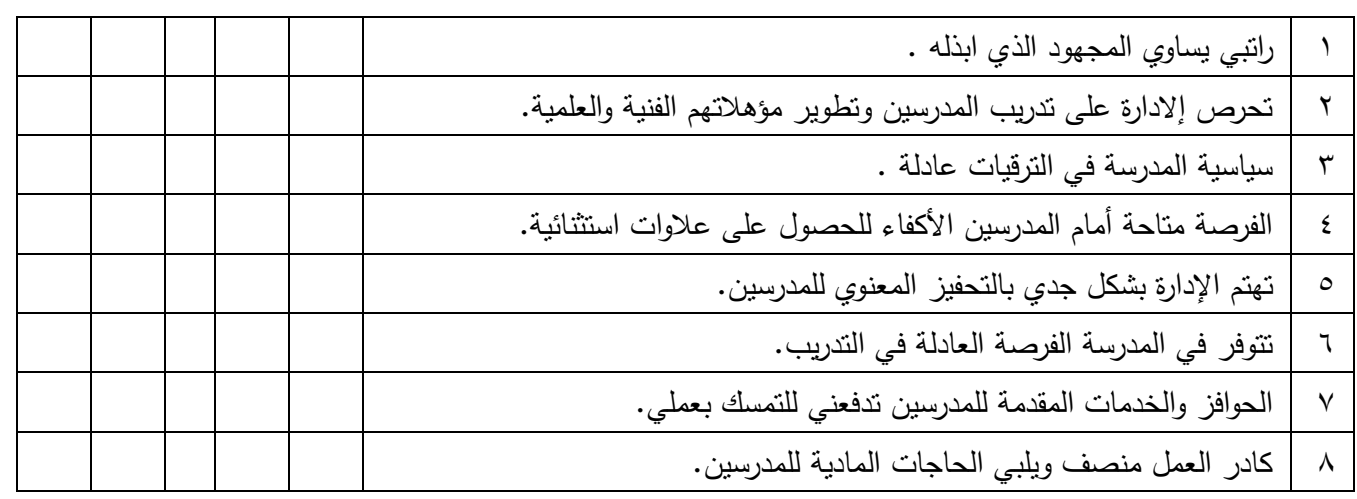

ץ- بعد ظروف العمل ( Working Conditions ) ) : (الثروط المادية التي يعمل فيها الددرسين

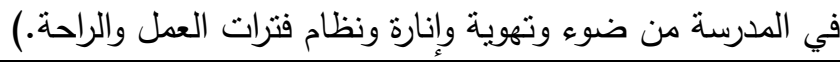

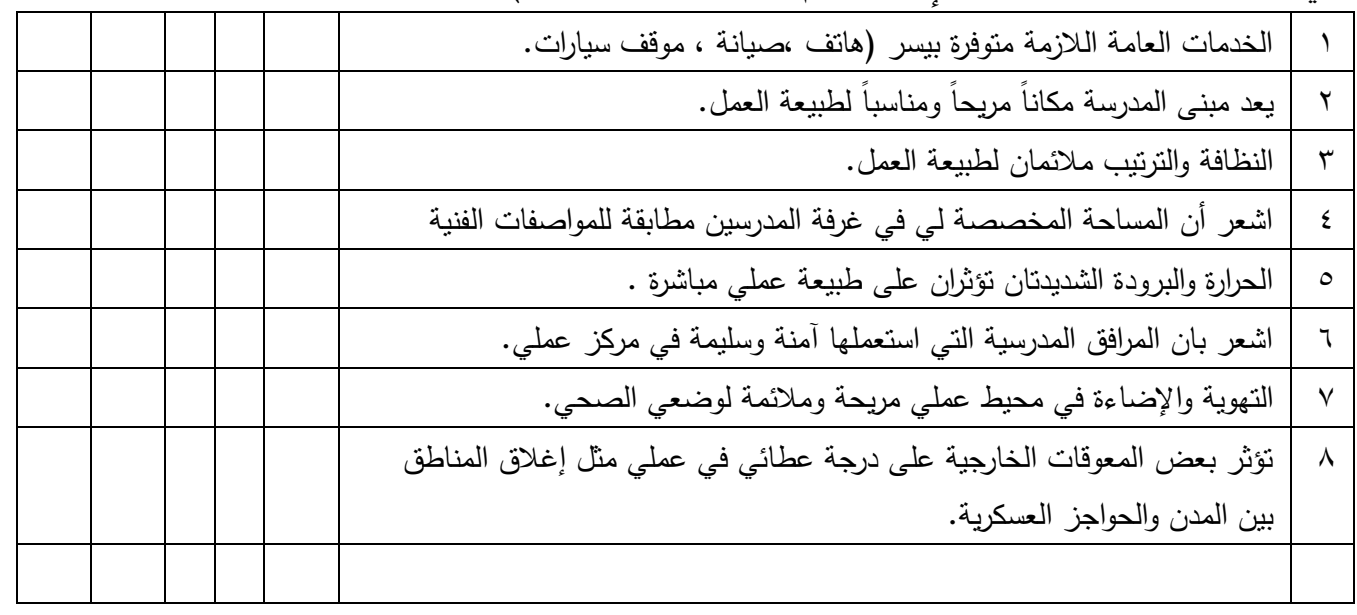

ع - بعد الأنظمة والتعليمات (The regulations and instractions ) : ( هي مجموعة

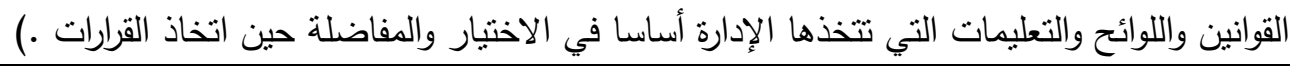

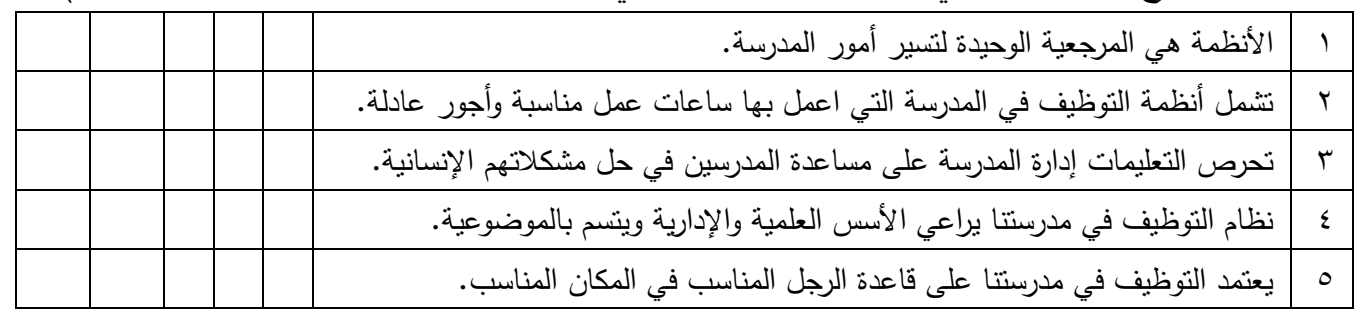


العـــــــد الثانـي والعشرون

مجلـــة كليــــة التربيــــة

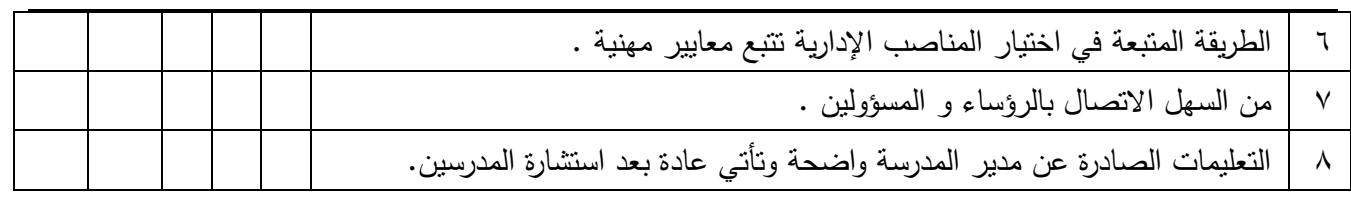




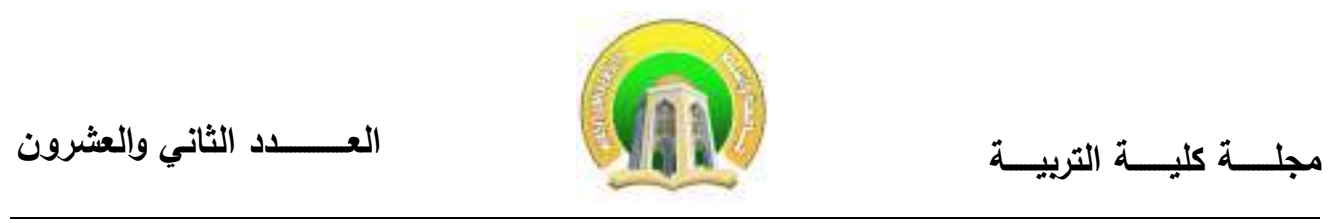

\begin{abstract}
The behavior of administrative managers and junior high school) system (1-4) of likret and its relationship to according to the theory of the morale teachers ' at the centre of Justice Kut
\end{abstract}

1.: the study is illustrated by the following

The be of this study have implications positive on the administrative field of Education, provide a sound basis to modify the practices and patterns of administrative behaviors of principals, reinforcing their relationship to the career of teachers, and offers ways to the success of the process of administrative, educational, the fact that the variable Morale is critical and . has impact on the output of the educational (students ) clearly

) If this study detected the level of the pattern, management under theory .prep school 2.( Likert

The objectives of the research : the research aims to identify the patterns of behavior of administrative managers and junior secondary schools according The statement of the relationship ، ليكرت (1) system the theory of rinses : in the morale of the teachers by answering to the following objectives

1.what degree of styles of management prevalent among the managers of junior secondary schools according to the theory of rinses

2.What is the degree of morale prevailing in the campuses of prep schools . from their point of view

3.is there a relationship statistically significant in the managerial behavior of type ( male the managers of junior secondary schools in accordance with the .and female ) and years of service

4.is there a correlation between the degree of patterns of management of four of the managers of junior secondary schools according to the theory .system (1-4) and the spirit and morale of teachers

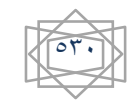



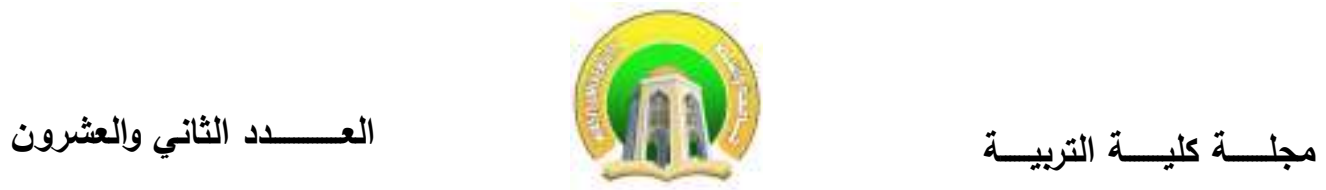

The limits of the research: is determined by this research, through: the boundaries of humanity : the school and teachers, and the border of the spatial : the preparatory schools at the centre of Justice Kut : timeline : 2014 2015

: Defining the terminology

( Styles of management : ( Administrative Styles

Conduct by the Director of the school effective influence in the behaviors of teachers in the school, with the aim of improving the quality of work and production in school, is measured by the degree of the College obtained by the Responder to the paragraphs of the tool to measure the level of patterns of . ( Likert) theory management

Morale(Morale ) "if Morale is a psychological phenomenon affected by the rise and wane of the many factors that are linked to the atmosphere and conditions of employment the physical, social, and psychological ( and $1999: 39$

Research approach : the use of the descriptive methodto clarify the relationship between the patterns of managerial behaviors according to the by the managers of junior secondary schools and . its relationship with morale of the teachers theory of rinses

Community research : the community research of all the teachers in junior secondary schools belonging to the Directorate General for the rearing of school at ( 355 ) (waist in the center of the spend the the Kut of the (694) . male(339) female

\section{: A sample search}

homogeneity of the society, the search has been withdrawn a random sample stratified to represent ( $36 \%$ ) of the Society of research of the kidney school, schools, prep, by (126 ) (and, therefore, the total sample ( 248) ‘teachers and (122) a school

: Conclusions : most important conclusions are the following

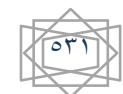




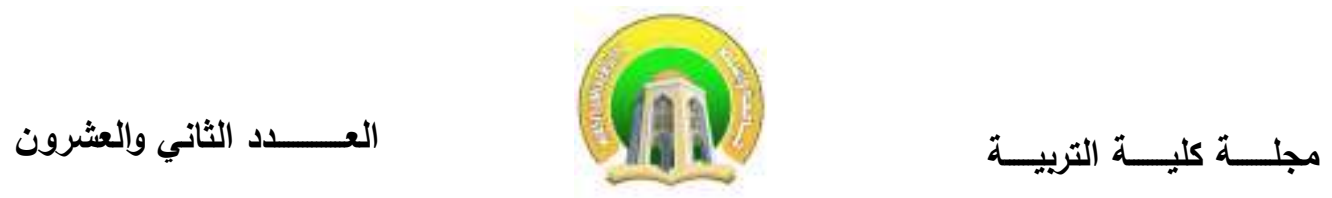

1. ) If the managers follow the conduct, issued according to the theory of 2.syste (1-4 is enough

the results showed that there is a rise in the morale of teachers in junior secondary schools in the center of the spend Kut

.weak between management behavior and The existence of a relationship .morale of teachers

Recommendations :one of the most important recommendations was the : following

strengthening the administrative conduct according to the theory of 2..system $(1-4)$ in secondary school

system (1- ) emphasis on follower behavior to the administrative theory of 3..Junior secondary schools ( 4

4..support the relationship between the administrative behaviors according system (1-4 ) and the spirit of the moral, because it is not the to the theory of . level of ambition

: Proposals : it is proposed that the researcher

further studies of the application of behavior management the theory

1.system (1-4 with the other variables in middle school

2.conduct a study to determine the morale and its relationship to the quality of Education 